\title{
Glacier fluctuations during the past 2000 years
}

Olga N.Solomina ${ }^{\mathrm{a}}$, Raymond S.Bradley ${ }^{\mathrm{b}}$, Vincent Jomelli ${ }^{\mathrm{c}}$, Aslaug Geirsdottir ${ }^{\mathrm{d}}$, Darrell S. Kaufman $^{\mathrm{e}}$, Johannes Koch ${ }^{\mathrm{f}}$, Nicolas P. McKay ${ }^{\mathrm{e}}$, Mariano Masiokas ${ }^{\mathrm{g}}$, Gifford Miller ${ }^{\mathrm{h}}$, Atle Nesje $^{\mathrm{i}, \mathrm{j}}$, Kurt Nicolussi ${ }^{\mathrm{k}}$, Lewis A. Owen ${ }^{1}$, Aaron E. Putnam ${ }^{\mathrm{m}, \mathrm{n}}$, Heinz Wanner ${ }^{\mathrm{o}}$, Gregory Wiles $^{\mathrm{p}}$, Bao Yang ${ }^{\mathrm{q}}$

anstitute of Geography RAS, Staromonetny-29, 119017, Staromonetny, Moscow, Russia

${ }^{\mathrm{b}}$ Department of Geosciences, University of Massachusetts, Amherst, MA 01003, U.S.A.

'Universite' Paris 1 Pantheon-Sorbonne-CNRS Laboratoire de Geographie Physique, 92195 Meudon, France

${ }^{\mathrm{d}}$ Department of Earth Sciences, University of Iceland, Askja, Sturlugata 7, 101 Reykjavík, Iceland

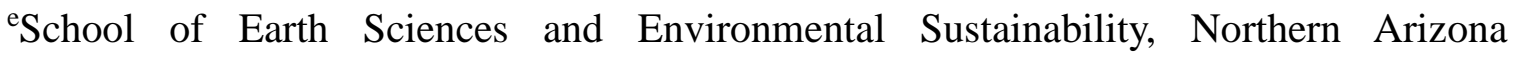
University, Flagstaff, Arizona 86011, USA.

fDepartment of Geography, Brandon University, Brandon, MB, R7A 6A9

${ }^{\text {g} I n s t i t u t o ~ A r g e n t i n o ~ d e ~ N i v o l o g i ́ a, ~ G l a c i o l o g i ́ a ~ y ~ C i e n c i a s ~ A m b i e n t a l e s ~(I A N I G L A), ~ C C T ~}$ CONICET Mendoza, CC 330, Mendoza, Argentina

${ }^{\mathrm{h}}$ INSTAAR and Geological Sciences, University of Colorado Boulder

(C) 2016. This manuscript version is made available under the Elsevier user license http://www.elsevier.com/open-access/userlicense/1.0/ 
${ }^{i, j}$ Department of Earth Science, University of Bergen, Allégaten 41, N-5007 Bergen, Norway and Uni Research Climate AS at Bjerknes Centre for Climate Research, Bergen, Norway.

kInstitute of Geography, University of Innsbruck, Innrain 52, 6020 Innsbruck, Austria

'Department of Geology, University of Cincinnati, Cincinnati, OH 45225, USA

${ }^{\mathrm{m}, \mathrm{n}}$ School of Earth and Climate Sciences and Climate Change Institute, University of Maine, Orono, ME 04469 USA, Lamont-Doherty Earth Observatory, 61 Rt 9W, Palisades, NY 10964

${ }^{\circ}$ Institute of Geography and Oeschger Centre for Climate Change Research, University of Bern, Switzerland

pDepartment of Geology, The College of Wooster, Wooster, OH 44691, USA

${ }^{\mathrm{q}}$ Cold and Arid Regions Environmental and Engineering Research Institute, Chinese Academy of Sciences, 320 Donggang West Road, 730000 Lanzhou, China.

* Corresponding author

Staromonetny-29, Moscow, Russia, 119017

E-mail address: olgasolomina@yandex.ru 
Phone number: +7-962-973-04-92

Abstract

A global compilation of glacier advances and retreats for the past 2 millennia grouped by 17 regions (excluding Antarctica) highlights the nature of glacier fluctuations during the late Holocene. The dataset includes 275 time series of glacier fluctuations based on historical, tree-ring, lake sediment, radiocarbon and terrestrial cosmogenic nuclide data. The most detailed and reliable series for individual glaciers and regional compilations are compared with summer temperature and, when available, winter precipitation reconstructions, the most important parameters for glacier mass balance. In many cases major glacier advances correlate with multi-decadal periods of decreased summer temperature. In a few cases, such as in Arctic Alaska and Western Canada, some glacier advances occurred during relatively warm wet times. The timing and scale of glacier fluctuations over the past 2 millennia varies greatly from region to region. However, the number of glacier advances shows a clear pattern for the high, mid and low latitudes and, hence, points to common forcing factors acting at the global scale. Globally, during the first millennium CE glaciers were smaller than between the advances in 13th to early 20th centuries CE. The precise extent of glacier retreat in the first millennium is not well defined, however, the most conservative estimates indicate that during the 1st and 2nd centuries in some regions glaciers were smaller than at the end of 20th/early 21 st centuries. Other periods of glacier retreat are identified regionally during the 5th and 8th centuries in the European Alps, in the 3rd-6th and 9th centuries in Norway, during the 10th-13th centuries in southern Alaska, and in the 18th century in Spitsbergen. However, 
no single period of common global glacier retreat of centennial duration, except for the past century, has yet been identified. In contrast, the view that the Little Ice Age was a period of global glacier expansion beginning in the 13th century (or earlier) and reaching a maximum in 17th-19th centuries is supported by our data. The pattern of glacier variations in the past 2 millennia corresponds with cooling in reconstructed temperature records at the continental and hemispheric scales. The number of glacier advances also broadly matches with periods showing high volcanic activity and low solar irradiance over the past 2 millennia, although the resolution of most glacier chronologies is not enough for robust statistical correlations. Glacier retreat in the past 100-150 years corresponds to the anthropogenic global temperature increase. Many questions concerning the relative strength of forcing factors that drove glacier variations in the past 2 ka still remain.

Key words: Late Holocene; glacier variations; Neoglacial; modern glacier retreat; temperature change; Little Ice Age; solar and volcanic activity

\section{Introduction}

Glaciers are sensitive climate proxies and variations in their length, area and volume provide insights into past climate variability, placing contemporary changes into a longterm context (Oerlemans, 1994, 2001; Hoelzle et al., 2003). A strong argument for the sensitivity and reliability of the glacier record is made by their relatively uniform retreat to contemporary warming (Vaughan et al., 2013). 
A detailed analysis of Holocene glacier fluctuations from 17 regions and their relationship to potentially important forcing factors was presented in Solomina et al. (2015). Solomina et al. (2015) demonstrated a general trend of increasing glacier size from the early-mid Holocene to the late Holocene in the high and mid latitudes of the Northern Hemisphere and possible forcing by orbitally-controlled insolation. Glaciers advanced in the second half of the Holocene between 4.4-4.2 $\mathrm{ka}$ ( $\mathrm{ka}=$ thousand years), 3.8-3.4 ka, 3.3-2.8 ka, at 2.6 ka, and between 2.3-2.1 ka, 1.5-1.4 ka, 1.2-1.0 ka, and 0.7$0.5 \mathrm{ka}$. These ice expansions generally correspond with episodes of cooling in the North Atlantic and provide a record of cool summers with an approximate century-scale resolution.

Even though the quality and replication of data on Holocene glacier variations has dramatically improved in recent decades, the accuracy of dating advances and retreats is still limited. This dating uncertainty makes it difficult to draw firm conclusions about the synchronicity of glacial advances from different regions and therefore direct comparison with high resolution proxy reconstructions is a challenge (Winkler and Matthews, 2010). The chronology of glacier fluctuations for the past two millennia is a more reliable climate proxy than earlier in the Holocene, as the ages of moraines are more precisely known, and the spatial coverage of the record is more dense. The possibility of dating advances to the calendar year with tree rings and historical data increases the resolution of the more recent portion of the records. Additionally, comparisons with high resolution reconstructions of summer temperature and winter precipitation from tree-rings, ice cores, and lake sediments helps identify potential climatic factors that may have driven glacier fluctuations. Glacier variations themselves can be used for low frequency records 
of temperature and precipitation especially when they are combined with other proxies (e.g. Dahl and Nesje, 1996; Luckman and Villalba, 2001; Nesje et al., 2001; Nesje and Dahl, 2003) or associated with modeling studies (Leclercq and Oerlemans, 2011; Oerlemans, 2012; Leclercq et al., 2012; Marzeion et al., 2014).

Glacier variations of the past 2 millennia are usually considered in the context of Holocene glacier fluctuations as the latest part of the "Neoglaciation" (after $4.5 \mathrm{ka}$ ) (Porter and Denton, 1967; special issues of Quaternary Science Reviews v. 7, issue 2, 1988 and v. 28, 2009 "Holocene and Latest Pleistocene Alpine Glacier Fluctuations: A Global Perspective"; Wanner et al., 2011). Two other terms are often used in the discussion of the environmental changes of the past 2 millennia: the "Medieval Climatic Anomaly" (MCA) or "Medieval Warm Period" and the "Little Ice Age" (LIA). Although there is little agreement in the literature on the definition of these terms, in this paper we will use the following approximate boundaries: 950 to $1250 \mathrm{CE}$ for the MWP/MCA and $\sim 1250$ to $\sim 1850$ CE for the LIA (IPCC AR5, 2013).

In this paper we will focus on the following questions:

- What was the extent of glacier fluctuations in the past $2 \mathrm{ka}$ and how does these compare with the contemporary glacier retreat?

- What was the magnitude of glacier fluctuations in the past two millennia and how does this compare with contemporary glacier retreat?

- How does the timing and magnitude of glacier variations relate to orbital, solar, volcanic and greenhouse gas forcings? 


\section{Approach, data, methods, accuracy of the records}

The approach used here is generally the same as in Solomina et al. (2015) although it is applied to the past 2 millennia and focused on higher frequency glacier variations. We provide a compilation of glacier fluctuations taking into account both continuous and discontinuous time series for both glacier advances and retreats of glaciers. We compile and analyze both individual glaciers and regional summaries (Table 1, Supplementary Materials (SM). We selected the best-dated and most complete time series of glacier fluctuations preferably completely covering the past two millennia. Periods of advances and retreats are identified by historical data, tree remains, ages of moraines, derived from dendrochronology, terrestrial cosmogenic nulcides (TCNs) and radiocarbon dating, as well as the information from lake and marine sediments. In Solomina et al. (2015, SM) the reader can find a detailed description of the methods used for the reconstruction of glacier fluctuations. Below we briefly summarize the challenges related specifically to the past two millennia.

Historical data (maps, pictures, written documents) used for the reconstruction of glacier variations is valuable and precise, but limited in time and to specific regions (Ladurie, 1971; Grove, 2004; Zumbühl et al., 2008; Masiokas et al., 2009a, b; Nussbaumer et al., 2011a,b; Nussbaumer and Zumbühl, 2012). In several mountain regions, for example Scandinavia, the earliest historical data are from the late 17 th century. Information based on tree rings can also be of high quality and chronologically accurate. Unlike historical sources tree-ring data can cover longer periods, up to several millennia (e.g. Nicolussi and Schlüchter, 2012), and it can be applied in areas where the historical descriptions of 
glaciers are absent. Trees growing on moraines provide minimum ages of these surfaces (McCarthy and Luckman, 1993; Wiles et al., 1995; Koch et al., 2009), whereas trees damaged or tilted by advancing glaciers can be used for more precise identification of the ages of glacial expansions (Koch et al., 2007b; Nicolussi and Patzelt, 2001; Nicolussi et al., 2006; Masiokas et al., 2009 a,b; Bushueva and Solomina, 2012; Hochreuther et al., 2015; Solomina et al., 2015). Interesting results have also been obtained from wood buried in glacial or glacio-fluvial deposits, although the link between glacier activity and the death of a tree is not always clear (e.g. Nazarov et al., 2012).

Dendrochronologically-based calendar-dated glacier chronologies of high quality and accuracy are available now in several regions, such as Alaska (Wiles et al., 2011; Barclay et al., 2009, 2013), the Alps (Nicolussi and Patzelt, 2001; Holzhauser et al., 2005; Le Roy et al., 2015), British Columbia (Reyes and Clague, 2004; Koch et al., 2007a, b) and the southern Andes (Masiokas et al., 2009a,b). The most distinct information arises from in situ tree remains overridden and embedded during advances or buried by end moraines. Due to a possible loss of some external rings through decay and abrasion, the ages of advances identified from this kind of material are maximum-limiting ages, but they are generally rather close to the actual ages of advances. Le Roy et al. (2015) showed that the trees that are not rooted but reworked, can also be used for accurate dating of glacier advances. The youngest age from stratigraphically defined wood layers provides the age of a glacier advance, whereas the age of the oldest ring of these trees limits the period of their undisturbed growth and ice-free intervals. This kind of information is extremely important to identify the scale of former glacial recessions as well. 
Radiocarbon dating of organic material is still the most common way to develop glacial chronologies, as it is useful both to define the age of moraines and to construct the agedepth models for lake sediments and even ice cores. The development of the AMS techniques has allowed a substantial increase in the accuracy of this dating by requiring smaller sample sizes. Some challenges of dating with ${ }^{14} \mathrm{C}$ dating remain and they are related to the uncertainties of dating within radiocarbon plateaus when ${ }^{14} \mathrm{C}$ concentrations remained constant for a period of time and thus spanning multiple intercepts of the radiocarbon calibration curve over long period (Lotter et al., 1992). In the past two millennia precise ${ }^{14} \mathrm{C}$ dating is problematic for the period since $\mathrm{CE} \sim 1600$. This is unfortunately the case as this period coincides with several most prominent advances and subsequent retreat.

The emergence of landscapes from beneath ice after centuries to millennia has led to new information on past ice extent and to discussions of their intepretations (Miller et al., 2012; Lowell et al., 2013; Koch et al., 2014). In situ rooted tundra plants that have brief life cycles (e.g. mosses) collected at the margins of cold-based non-erosive ice caps date to the time when they were buried by permanent snow ("the vegetation-kill-dates") (Miller et al., 2012; 2013). Miller et al. (2013) suggested that these are direct records of the time when ice advanced and then did not retreat until the recent time as the vegetation is exposed. Lowell et al. (2013) argue with this concept and defend a different interpretation pointing to a disagreement between the reconstructions based on the "kill dates" and the ones based on lake sediment records in Greenland. 
We report all dates here, including those based on $14 \mathrm{C}$ analysis, as $\mathrm{CE}$ calendar dates. We use a time scale at the beginning of the Common Era (labeled as CE); events before the year $1 \mathrm{CE}$ are labeled as BCE. Centuries and millennia considered here are not labelled as they are all of the Common Era.

In this paper we treated the $14 \mathrm{C}$ dates of glacier advances and retreats as the calibrated radiocarbon ages reported in the original publications. We recalibrated inividual $14 \mathrm{C}$ dates if they are directly constraining advances or retreats from the papers published earlier than 2004 using the uniform approach of considering one-sigma intervals, with Calib7.1 (Stuiver et al., 2005). The calibration curves INTCAL04 and INTCAL13 (Reimer et al., 2013) are identical for the past 2000 years, so the dates published since 2004 do not require recalibration. For consistency we report these recalibrated dates as $\mathrm{CE}$; the corresponding original $14 \mathrm{C}$ dates with the laboratory numbers (when available in the original publications) are reported Table 1 of Supplementary Materials as well as the reservoir correction details.

Most of the dates on advances and retreats are based on the assessments by the regional experts inferred from collections of $14 \mathrm{C}$ dates as well as other sources (geomorphological, stratigraphical, historical information, tree rings etc.). In these cases we do no recalculations and new assessments, but rely on the choices made by the experts concerning the age range of glacier events including the use of one or two standard deviations, multiple intercepts etc. In addition, we did not recalibrate the dates for tephras and the dates for lake, peat, and marine sediments if they provide age control for models of the rates of sedimentation. 
Surface exposure dating using terrestrial cosmogenic nuclides (TCNs) $\left({ }^{10} \mathrm{Be},{ }^{14} \mathrm{C},{ }^{26} \mathrm{Al}\right.$, ${ }^{36} \mathrm{Cl},{ }^{3} \mathrm{He},{ }^{21} \mathrm{Ne}$ etc.) is becoming one of the most widely used approaches to develop glacial chronologies. ${ }^{10} \mathrm{Be}$ is the most frequently employed for this purpose and details of the application of this method are described in several comprehensive publications (e.g. Gosse and Phillips, 2001; Balco, 2011; Granger et al., 2013) and in the Supplementary Material of Solomina et al., (2015). The TCN ages of moraines are single ages or more commonly the average of several samples. Recent progress, including the assessment of regional production rates for TCNs (Balco et al., 2009; Putnam et al., 2010; Fenton et al., 2011; Kaplan et al., 2011; Goehring et al., 2012; Young et al., 2013; Blard et al., 2013a,b; Kelly et al., 2013; Stroeven et al. 2015; Martin et al., 2015) allow for the dating of moraines with the necessary accuracy that is reasonable for the analyses of centennial and sometimes even multidecadal events for the past two millennia.

In this paper we report the TCN ages of moraines that in most cases were calculated with the updated local production rates and the time-dependent Lal/Stone scaling scheme (Stone, 2000). Recalculation with the most updated local production rate was made here for the Tropical Andes (Hall et al., 2009, Licciardi et al., 2009; Jomelli et al., 2014; Stroup et al., 2014, 2015). The dates from New Zealand by Schaefer et al. (2009) were recalculated and reported by Putnam et al. (2012) and are reproduced here. The dates from Greenland (Kelly et al., 2008; Levy et al., 2014) were recalculated here using Young et al. (2013) approach. For Central Asia we report the original dates: Owen et al. (2008) demonstrated that the difference between different time-dependent scaling models is about 10\% (Lal, 1991/Stone, 2000, Desilets et al., 2006, Dunai, 2001, Lifton et al., 2008, 2014). The TCN ages are reported here in CE with its requisite standard error. The 
ka (kiloyears ago) ages are transformed in CE by subtracting the ka dates from the years of measurement/publication.

Lichenomentry has been widely used to estimate the relative and numerical age of glacial deposits of the past two millennia (Beschel, 1950). Recent attempts to improve the lichenometric technique have been primarily focused on statistical approaches (Jomelli et al., 2007, 2009; Naveau et al., 2007). On some occasions the lichenomentric ages generally agree with the reported ${ }^{10} \mathrm{Be}$ ages for moraines (Badding et al., 2013; Munroe et al., 2013). However, several significant problems, including lichen species identification, growth rate dependence on microenvironmental conditions and poor chronological control of growth calibration curves remain unresolved. Osborn et al. (2015) showed that lichenometric ages may not be reliable and it is a challenge to distinguish between those that provide realistic and erroneous ages. We agree with this view, but believe that estimating the age of deposits using well defined growth curves can be useful in distinguishing different generations of moraines (relative dating). Certainly, lichenometric studies should be undertaken more carefully and be better documented. Some of the problems mentioned above may be overcome be applying TCN methods with the lichenometry. We include lichenometric dates in our paper only if they are supported by other lines of evidence.

In many cases, information on the former extent of glaciers has been erased or obscured by subsequent more extensive ice expansions. Thus other, less direct methods, to infer past glacial activity have been developed (e.g. Nesje et al., 1991). The use of lacustrine sedimentary sequences from glacier-fed lakes to reconstruct Holocene glacier variations 
in the catchment was pioneered by Karlén (1976) in Swedish Lapland and widely used in Scandinavia (Karlén, 1988; Nesje and Kvamme, 1991; Nesje et al., 1991; 1994, 2000a,b, 2001, 2006; Karlén and Matthews, 1992; Dahl et al., 2003; Lie et al., 2004; Bakke et al., 2005a,b,c, 2010; Vasskog et al., 2012) as well as in other regions (e.g. Briner et al., 2010; Larsen et al., 2011; Osborn et al., 2007; Røthe et al., 2015). Physical, geochemical, and magnetic sediment properties along with other dating techniques (e.g. ${ }^{14} \mathrm{C}$ ages calibrated to calendar years and ${ }^{210} \mathrm{~Pb}$ ) can be used to contrain glacier chronologies. Studies of lacustrine records include loss-on-ignition, water content, dry weight, dry bulk density, grain-size distribution, magnetic susceptibility, biogenic silica, X-ray florescence (XRF), and in situ reflectance spectroscopy. Varves in proglacial lake sediments are often indicative of glacial activity (Larsen et al., 2011; Zolitschka et al., 2015), whereas the disappearance of a glacier from a catchment is usually marked by homogenous organicrich layers (Karlén et al., 1999; Zolitschka, 2007).

Peat deposits intercalated with thin mineral layers of glacier origin exposed along glacier meltwater channels can also yield information about the timing of glacier activity in the basin (Nesje and Dahl, 1991a,b; Nesje et al., 1991; Nesje and Rye, 1993; Dahl and Nesje, 1994, 1996; Matthews et al., 2005). In addition, radiocarbon dating of palaeosols and peat deposits buried underneath Neoglacial moraines has been used to reconstruct glacier-size variations (Mercer and Palacios, 1977; Matthews and Dresser, 1983). Tephrochronology was applied to constrain the age of moraines in regions of active volcanism, such as Iceland (Stötter et al., 1999) and Kamchatka (Solomina, 1999).

\section{Glacier fluctuations as climatic proxies. Terminology.}


Not all glaciers can be used as climate proxies. Large ice sheets and ice caps, surging glaciers, ice-shelves, outlet glaciers, calving glaciers and some other types of ice bodies have been often shown to not align with climate forcings (Paterson, 1994). The outlet glaciers of the Northern and Southern Patagonian ice sheets are classical examples of the contrasting behaviour of glaciers reflecting more their internal dynamic than climatic perturbations (Glasser et al., 2004). Warren and Anya (1999) drew attention to the instability, sensitivity to topography, and often, indirect response to climate variations, of calving glaciers. Issues related to supraglacial debris on glacier dynamics throughout the Himalayas and their relatiohship with glacial changes have also been discussed in depth, and we acknowledge the difficulty in assigning glacier fluctuations to climatic changes in these regions (Hewitt, 1988; Benn et al., 2005; Owen and Benn, 2005; Scherler et al., 2012). Ideally classical land-terminated valley glaciers of a simple configuration and hypsometry are the most suitable to infer paleoclimatic information (Oerlemans, 1994, 2001). Most glaciers considered in this paper are of this kind.

As in Solomina et al. (2015), we do not account for the response time of glaciers here, since the accuracy of most glacial chronologies even for the past two millennia is generally less than the response time of mountain glaciers. The lag in position of the glacier terminus, in relation to a climatic perturbation is generally estimated as $10-50$ years (Oerlemans, 1994) and often only a few years (Bjørk et al., 2012; Imhof et al., 2012).

Glacier variations as climate proxies, considering response times, the climatic drivers of glacier mass balance and fluctuations, the reaction of "specific" glaciers such as cold- 
based, surging glaciers, etc. were discussed in the Supplementary Materials in Solomina et al. (2015).

The Equilibrium Line Altitude (ELA) rise or depression is a useful paleoclimatic metric that can be assessed either from the location of terminal moraines or modelled using lake sediment properties. However a shift in ELA depends on glacier type and it varies from glacier to glacier and from region to region (Kuhn, 1989; Oerlemans, 2001; Zemp et al., 2007; Six, Vincent, 2014).

The terminology used to describe glacier fluctuations differs among workers. A glacier fluctuation is initiated as a glacier expands, reaches a stabilized position (commonly marked by an end moraine) and then retreats. In this review the term "advance" is not used literally to connote the onset or progression of a glacier expansion. Instead, the term "advance" is used loosely; it most commonly refers to the interval when a glacier is near its maximum position as evidenced by geomorphic features, although in some cases where stratigraphic evidence is available, the term is also used to refer to the early stage of glacier expansion. In case of lake sediments it encompasses both. We recognize that many of the ages used to determine the timing of "advances" actually constrain the timing of moraine stabilization, and therefore represent the initiation of retreat rather than an "advance". Furthermore, in this review the term "glacier activity" is used to refer to the relative abundance of evidence for expanded glaciers rather than the activity of a glacier as measured by the down-valley throughput (flux) of ice. Taking into account the typical uncertainty associated with the dating ranging from a half century to a century we can assume that this approach, although very rough, is reasonable at the current stage of 
knowledge. In most cases the actual precision of the dates does not allow to distinguish between "the beginning of the ice retreat" and "the end of the ice advance", so we consider here the ages of moraines as approximate time of glacier advances as most of our predecessors (e.g. Grove, 2004 and references herein)

\section{Regional descriptions of glacier variations in the past two millennia}

The regional subdivision in this paper is similar to Solomina et al. (2015), who generally followed the recommendations of IPCC AR5 (Vaughan et al., 2013). We do not include Antarctica in this paper, as we could not find enough detailed and well-dated records for individual glaciers.

\subsection{Alaska}

In the southern coastal region of Alaska, fluctuations of tidewater glaciers have been shown to not reflect climate directly (Wiles et al., 1995; Barclay et al., 2009a) on decadal to century-scale periods. We thus restrict our discussion in Alaska to those glaciers that are land-terminating and whose chronologies are considered to more accurately reflect climate (Barclay et al., 2013).

The chronology of land-terminating glaciers in southeast coastal Alaska, Eagle, Mendenhall, and Herbert glaciers, as well as outlets of the Juneau Icefield, show advances between CE $\sim 200$ and $\sim 320$ according to radiocarbon ages (Rothlisberger, 1986). An advance occurred in the Wrangell Mountains about CE 300 (Wiles et al., 2002). Other evidence of ice expansion at this time is rare. Widespread periods of

advance between CE 550 and 720 based on ${ }^{14} \mathrm{C}$ and tree-ring dating is recognized in the 
Alaska Range, St. Elias, Chugach, Kenai Mountains and adjacent ranges in Canada (Reyes et al., 2006; Barclay et al., 2009b, 2013; Young et al., 2009; Zander et al., 2013), with most frequently documented expansion around CE 600 (Reyes et al., 2006). Trees preserved in glacial sediments near the margin of many retreating glaciers, primarily along the southern coast, germinated by the CE 950s following the first millennium advances (Wiles et al., 2008; Barclay et al., 2009a, b) implying that ice was less extensive during that time or at about the same extent as present retreating margins. However, ice retreat was not uniform here, and several glaciers advanced through this interval (Wiles et al, 1995; Barclay et al., 2009a,b; Koch and Clague, 2011; Figure 2).

The majority of the advances recognized in the glacial record over the past millennium occurred in the CE 1180s-1320s, 1540s-1710s and 1810s-1880s (Barclay et al., 2009a,b, 2013). Most forefields along the coast and into the more interior Wrangells reached their Holocene maxima during the latter CE 1800s. To the west in the Aklun Mountains, glaciers reached their maximum Holocene extent as early as CE 1300 with less extensive moraine building through CE 1800 (Levy et al., 2004). Along the southern coast, most glaciers reached their Holocene maxima in the past few centuries. However, some glaciers in the Alaska Range (Bijkerk, 1984) and one in the Wrangell Mountains (Wiles et al., 2002) show a more extensive first millennium advance.

In general summer temperature is the primary limiting factor for land terminating glaciers along the southern coast of Alaska in the Kenai, Chugach, St. Elias and the Coast Mountains (Barclay et al., 1999, 2013, Wiles et al., 2004) (Figure 2). Advances during the first millennium CE correspond with cooling recognized in lake sediments at Farewell 
Lake in the Alaska Range (Hu et al., 2001) at about this time. The interval of retracted ice margins about CE 950 corresponds with warming along the southern coast recognized in a regional dendroclimatic reconstruction (Wiles et al., 2014).

The majority of advances occur within the intervals of cooling apparent in a FebruaryAugust temperature reconstruction for coastal southern Alaska with temperature minima centered on CE 1200, 1450, 1650 and the 1800s (Figure 2 A) (Wiles et al., 2014). A JulyAugust summer temperature reconstruction based on latewood density in the Brooks Range (Anchukaitis et al., 2013) shows a general similarity with glacial records of the past nine centuries with cooler summer temperatures and ice expansion coinciding with the CE 1300 and CE 1800 advances. However, the tree-ring reconstruction (Anchukaitis et al., 2013) and a summer temperature record derived from sedimentary chlorophyll (Boldt et al., 2015) show that the CE 1600 advance occurred during a time of warm summer temperatures, and thus this advance may have been facilitated by increased winter precipitation. In the $20^{\text {th }}$ century, glacier retreat for land-terminating glaciers has dominated in agreement with rising temperature (Molnia, 2008).

\subsection{Western Canada and US}

Evidence for glacier advances during the first millennium CE is widespread in the western Cordillera of North America outside of Alaska (Luckman, 2000; Reyes and Clague, 2004; Allen and Smith, 2007; Koch et al., 2007a; Jackson et al., 2008; Menounos

et al., 2009; Clague et al., 2010; Samolczyk et al., 2010; Bowerman and Clark, 2011; Craig et al., 2011; Johnson and Smith, 2012; Maurer et al., 2012; Coulthard et al., 2012; Munro et al., 2012; Osborn et al., 2012; Craig and Smith, 2013; Hoffman and Smith, 
2013; Mood and Smith, 2015), but glacier extent generally appears to have been smaller than during advances of the past millennium. Some glaciers were likely smaller before CE 500 than in the late $20^{\text {th }}$ century (Allen and Smith, 2007; Clague et al., 2010), even though other glaciers seem to have advanced during that same period (Jackson et al., 2008; Samolczyk et al., 2010; Maurer et al., 2012; Osborn et al., 2012; Hoffman and Smith, 2013). Many locations had advances between CE 400-600, before glaciers retreated to some degree. However, no sites studied show evidence that glaciers receded to sizes similar to the late $20^{\text {th }}$ century, after the first millennium advance. Rather, numerous sites provide evidence of significant advances during Medieval times (MCA) between the advances of the first millennium and those of the early 2 nd millennium $\mathrm{CE}$ (Koch and Clague, 2011; Johnson and Smith, 2012; Munroe et al. 2012; Osborn et al., 2013).

Most glaciers reached their maximum Holocene extent in the second millennium CE (Luckman, 2000; Menounos et al., 2009), prior to CE 1850 (Koch et al., 2007b; Clague et al., 2010; Hoffman and Smith, 2013), and remained at their maxima until the early $20^{\text {th }}$ century (Luckman, 2000; Koch et al., 2007b; Menounos et al., 2009). Glaciers fluctuated, but were more extensive than at present, between about CE 1200-1500, and it appears that several glaciers advanced synchronously during this period in the Rocky and Coast mountains (Luckman, 1995; Koch et al., 2007b; Coulthard et al., 2012). Some moraines in western Canada were possibly deposited during this advance (Koch et al., 2007b; Osborn et al., 2007; Koehler and Smith, 2011). Major moraine-building phases in the mountains of western North America date to CE 1690-1730, 1830-1850, 1860-1890, and 1910-1930 (Luckman, 2000; Luckman and Villalba, 2001; Osborn et al., 2001; Allen and 
Smith, 2007; Koch et al., 2007b; Osborn et al., 2007, 2012; Jackson et al., 2008; Clague et al., 2010; Bowerman and Clark, 2011; Koehler and Smith, 2011; Maurer et al., 2012; Munroe et al., 2012; Coulthard et al., 2012; Mood and Smith, 2015).

A tree-ring record from the central Canadian Rockies extends from CE 950-1994 and provides a reconstruction of May-August maximum temperature. Cold periods occurred in CE 950-1000, 1200-1320, 1450-1880, with the CE 1690s being exceptionally cold (Luckman and Wilson, 2005). A tree-ring chronology from the central British Columbia Coast Mountains spans CE 1225-2010 and allows the reconstruction of regional JuneJuly air temperature. Intervals of below average temperatures occurred CE 1350-1420, 1475-1550, 1625-1700, and 1830-1940 (Pitman and Smith, 2012). A reconstruction based on tree-rings and pollen data (Viau et al., 2012) for temperate North America for the past 1500 years shows below average temperature for CE 480-750 and CE 1100-1900 with distinct cool periods around CE 1300, 1650-1700, and 1800-1900 (Trouet et al., 2013) (Figure 2).

Annual precipitation (July-June) has been reconstructed for the southern Canadian Cordillera for up to the past 600 years with tree-ring chronologies. Wet conditions were reconstructed for most chronologies for CE 1680-1700, 1750-55, 1780-1790, 1800-1830, and 1880-1890. Earlier wet periods, with fewer chronologies dating back this far, are CE 1540-1560, 1600-1620, and 1660-1670 (Watson and Luckman, 2004). Winter precipitation (November-February) in eastern Washington State was reconstructed for the past 1500 years from lake sediment oxygen isotope data, and above average wet periods occurred CE 560-730, 770-840, 900-960, 1050-1150, 1300-1460, and 1570-1620 
(Steinman et al., 2012). Spring droughts for southern Vancouver Island on the west coast of British Columbia have been reconstructed from tree-rings. The reconstructions record severe and multi-decadal droughts in CE 150-200, 540-570, 760-810, 1440-1570, and 1845-1850 (Zhang and Hebda, 2005).

The climate reconstructions outlined above make it difficult to simplify the direct forcing of climate on glacier fluctuations due to the very large area under discussion with complex climatic pattern and great variety of glacier types. In the Canadian Rocky Mountains glacier advances coincide with low summer temperature in CE 1200s-1300s, late CE 1600s through early CE 1700 s, and in the 19th century, while precipitation changes do not show any significant correlation with the dates of glacier advances (Luckman and Villalba, 2001). In general, especially during the second half of the past millennium, it appears that below-average summer temperatures and above-average wet periods can account for much of the reconstructed glacier advances; however, there are exceptions such as during CE 800-1400, when relatively warm summers and wetter winters are reconstructed, which likely explain the significant glacier advances in western North America during this time (e.g. Llewellyn Glacier in northwest British Columbia, glaciers in Garibaldi Provincial Park in southwest British Columbia, Robson, Kiwa, and Peyto glaciers in the Canadian Rockies (Koch and Clague, 2011).

\subsection{Canadian Arctic}

A sufficient number of $14 \mathrm{C}$ ages of in situ rooted tundra plants found at glacier margins are now available for Baffin Island, Arctic Canada for the past two millennia to allow reconstruction of periods of ice expansion (Anderson et al., 2008; Miller et al., 2012; 
2013; Margreth et al., 2014). Clusters of kill-ages suggest a significant expansion of local glaciers and ice caps on Baffin Island occurred early in the first millennium CE, between CE 250 and 400, with a second expansion interval between CE 800 and 950 (Fig. 2). There is little evidence for ice advance between CE 950 and CE 1250, but widespread ice expansion is recorded beginning about CE 1260, with irregular but generally continuously colder summers from CE 1280 until 1450 (Fig. 2). The signal provided by entombed plants vanishes after CE 1450 because ice cover was widespread. Historical observations and distinct lichen trimlines indicate that the maxima were achieved in the late CE 1800s (Miller et al., 2013). Margreth et al. (2014) show a similar record from southern Cumberland Peninsula, southeastern Baffin Island, with significant ice expansion beginning early in the first millennium CE. Clusters of kill ages provide evidence for expansion CE 400-500, and between CE 600 and 900, little evidence of ice expansion during the CE $11^{\text {th }}$-early $13^{\text {th }}$ centuries, and an early onset of significant glacier advances starting CE 1280 and a second pulse of advances around CE 1460. In the $19^{\text {th }}$ century the snowline in Baffin Island was almost $200 \mathrm{~m}$ below its position of the end of the $20^{\text {th }}$ century, while about two millennia ago it was at least $200 \mathrm{~m}$ above the modern level (Miller et al., 2013)

\subsection{Greenland}

Scarce data exist to define the extent of glaciers during the past two millennia in Greenland. Consequently it is still difficult to discuss potential synchronicity between the different regions, and correspondence of glacier fluctuation patterns to the regional 
climatic patterns at a multidecadal scale even for the relatively well-documented last century (Hall et al., 2008; Carlson et al., 2008; Weidick, 2009; Hughes et al., 2012).

The reconstructions of glacier fluctuations in Greenland are based on historical information (Weidick, 1958; 1968; Bennike, Weidick, 2001), 14C dating (Bennike, 2002; Kelly and Lowell, 2009; Bennike, Sparrenbom, 2007; Knudsen et al., 2008; Kelly and Lowell, 2009), TCN dating (Kelly et al., 2008; Lowell et al., 2013; Levy et al., 2014; Winsor et al., 2014; Young et al., 2015), and proglacial lake and marine sediments (Lloyd, 2006; Briner et al., 2010; 2011, 2013; Young et al., 2011; Larsen et al., 2011; Kelley et al., 2012; Balascio et al., 2015). The information was collected at the margins of ice sheet outlet glaciers (both marine/land terminated), as well as from local glaciers.

In northern Greenland (Washington Land) reworked shells in a moraine of Humboldt Glacier attest to an advance around CE 1300 (Bennike, 2002). The glacier has receded since its maximum advance around 100 years ago.

In central west Greenland marine cores just beyond the fjord mouth suggest that Jakobshavn Isbræ reached late Holocene maxima between CE 1200 and 1660 (Llyod, 2006). Additional $14 \mathrm{C}$ ages from plant macrofossils and varve chronologies from glacial lakes located close to Jakobshavn Isbræ show that both land-based and marine-based ice margins advanced between CE 1500 and 1640 and reached a maximum at 1850 (Briner et al., 2010; 2011; Young et al., 2011). This contrasts with other portions of the western land terminating Ice Sheet close (c. $40 \mathrm{~km}$ ) to Jakobshavn Isbræ, which only achieved their maxima during the $20^{\text {th }}$ century (Kelley et al., 2012). Most probably the difference is 
explained by the complex ice dynamic of marine-based and land-terminating parts of the ice sheet.

In western Greenland (Nuuk region) Weidick et al. (2012) reported asynchronous advances for land and marine terminating outlet glaciers over the past centuries from historical observations and lake sediment analysis. The land terminating Qamanaarssup Sermia and Kangaarssup Sermia may have reached their LIA maxima in the mid CE 1800 s and in the early $20^{\text {th }}$ century, respectively. During the past millennium marine terminating Saqqap Sermersua achieved its maximum in the early 2000s, while Nakkaasorsuap Glacier reached its maximum in the middle of the $19^{\text {th }}$ century (Weidick et al., 2012). A maximum advance over the past centuries of the Kangiata Nunaata Sermia Ice sheet marine outlet glacier at CE 300 was deduced from the analysis of lake sediments (Weidick et al., 2012).

In southwest Greenland, ${ }^{10} \mathrm{Be}$ dates the Narsarsuaq moraine of land terminating Kiagtut Sermia at CE $490 \pm 110$ (Winsor et al., 2014). A second set of ${ }^{10} \mathrm{Be}$ ages from a more iceproximal position of Kiagtut Sermia shows that ice has been within or near its present extent since CE $660 \pm 150$.

Inland ice and local glaciers in south and southwest Greenland began to advance around CE 1600 and reached maximum positions in CE 1750 and 1890-1900 (Weidick, 1968; Kelly and Lowell, 2009). These glaciers were retreating over the $20^{\text {th }}$ century with an average rate of $1.2 \pm 0.2 \mathrm{~km}$ (Leclercq et al., 2012). 
In southeastern Greenland at a nunatak located at the present-day ELA of Mittivakkat Glacier, organic material dating back to CE 500-600 was found, indicating a warmer interval and a subsequent glacier advance (Humlum and Christiansen, 2008; Knudsen et al., 2008; Kelly and Lowell, 2009).

In northeastern Scoresby Sound, ${ }^{10}$ Be ages show direct evidence of glacier advances between CE 1100 and 1660 (Kelly et al., 2008; Levy et al., 2014 - recalculated using Young et al 2013 production rate and Lal/Stone scaling scheme). In the same region, the maximum Holocene advance of the local Istorvet Glacier occurred between CE 1150 and 1660 based on radiocarbon and ${ }^{10}$ Be ages (Lowell et al., 2013).

\subsection{Iceland}

In Iceland the most prominent evidence for glacier advances during the Late Holocene is documented by glacier activity between CE 1300 and 1900, although, moraines formed by small glaciers also indicate fluctuations before CE 1300 (Caseldine, 1987; Caseldine and Stotter, 1993; Stötter et al., 1999; Kirkbride and Dugmore, 2001, 2006, 2008; Schomacker et al., 2003; Principato, 2008).

The most rigorously dated record of glacier advances in Iceland over the past two millennia is found in Hvítárvatn, a glacial lake adjacent to the second largest glacier of Iceland, Langjökull. A multibeam sonar bathymetry of the lake together with seismic reflection analyses revealed multiple glacial advances, which have been precisely dated with varve counts supported by the known tephra layers found within the sediment (Black et al., 2004; Geirsdóttir et al., 2008; Larsen et al., 2011, 2013, 2015; Geirsdóttir et al., 
2015). The evidence from Hvítárvatn demonstrates that the two outlet glaciers of Langjökull that drain into Hvitárvatn (Suðurjökull and Norðurjökull) have response times of about 100 years (Black et al., 2004; Flowers et al., 2008; Larsen et al., 2015). Langjökull achieved its maximum Neoglacial extent between CE 1700 and 1930, when the two outlet glaciers advanced into the lake and maintained active calving margins. Paleolimnological studies of sediment cores from Hvítárvatn indicate glacier expansion in the 5th and 13th centuries. Norðurjökull advanced into the Hvítárvatn basin around CE 1720 , and remained at or near its maximum for most of the 19th century, whereas Suðurjökull underwent a quasi-periodic series of eight surges between CE 1828 and 1930 (Larsen et al., 2015). A very similar pattern of glacier expansion is seen around small ice caps in northern Iceland where moraine features were mapped and dated by the use of tephrochronology and ${ }^{14} \mathrm{C}$ ages (Stötter et al., 1999).

The combined paleolimnology and glacier advance study from Hvítárvatn, central Iceland, shows a stepwise intensification of glacial activity until its culmination between CE 1300 and 1900 (Fig. 2; Larsen et al., 2011; Geirsdóttir et al., 2013). Langdon et al. (2011) identify particularly cold phases based on chironomid studies in NW Iceland for CE 1683-1710, 1765-1780, and 1890-1917, with summer temperature decreases of 1.5 to $2.0^{\circ} \mathrm{C}$ suggesting that the magnitude of summer temperature cooling resulted in Icelandic glaciers reaching their maximum Holocene extent at that time, as previously modeled for Langjökull (Flowers et al., 2007).

In south central Iceland a combination of tephrochronology and lichenometry was applied to date moraines, tills and meltwater deposits. Three glacier advances occurred between 
CE 450 and 550, and three more occurred between CE 900 and 1400. Five groups of advances occurred between CE 1650 and 1930 (Kirkbride and Dugmore, 2008). While glacier advances between CE 1600 and 1900 across Iceland appear to have been synchronous, the timing of maxima differs between glacier type and region from the early 18th to the late 19th century (e.g. Chenet et al., 2010).

\subsection{Spitsbergen}

Radiocarbon ages on organic material buried at or under the modern glaciers (Baranowski and Karlén, 1976; Humlum et al., 2005), sediment cores from proglacial lakes (Svendsen and Mangerud, 1997; Røthe et al., 2015), lichenometry (Werner, 1993) and ${ }^{10}$ Be ages on moraines (Reusche et al., 2014) have all been used to reconstruct glacier fluctuations of the past two millennia in Spitsbergen.

Since the 1970s several authors reported the ages (bulk) for organic material buried at glacier fronts in Spitsbergen and dating back to the first millennium CE, claiming that the glaciers were smaller or of equal sizes then compared to the end of the 20th century (e.g. Baranowski and Karlén, 1976; Furrer, 1992; Furrer, et al., 1991). Humlum et al. (2005) found frozen soil and vegetation in situ below the cold-based Longyearbreen. One soil and ten bryophyte samples were dated and yielded ages between CE 20 to 820, indicating that the glacier was $2 \mathrm{~km}$ shorter than in the early $21 \mathrm{st}$ century for at least 800 years and possibly longer. Snyder et al. (2000) demonstrated that the Linnevatnet cirque was ice free until about CE 1400. 
However there is also evidence of several glacial advances in Spitsbergen in the first millennium CE. An advance at CE $350 \pm 200$ is documented by ${ }^{10} \mathrm{Be}$ dating of a moraine at Linnébreen in western Svalbard (Reusche et al., 2014). The advance was close or even a little larger than the past millennium maximum extent, that the glacier occupied up to CE 1930 (Svendsen and Mangerud, 1997). Somewhat earlier, an advance of Karlbreen around CE 250 is recorded in lake sediments at Mitrahalvøya (Røthe et al., 2015). Sediment records in Kongressvatnet point to possible minor glacial events at CE 700-820 and CE 1160-1255 (Guilizzoni et al., 2006), but this evidence needs replication and confirmation.

Glacial activity in Spitsbergen increased in the mid $14^{\text {th }}$ century. Continuous sequences of glacial varves in Kongressvatnet were deposited between CE 1350 and 1880 (Guilizzoni et al., 2006). The deposition of glacial sediments in Billefjorden indicates the increase of activity of Nordenskioldbreen at CE 1520-1900, or perhaps a little earlier (by CE 1425) (Szczuciňski et al., 2009).

Lake sediments at Mitrahalvøya provide information that Karlbreen was probably close to its Holocene maximum at CE 1725 and 1815 (Røthe et al., 2015). Many glaciers in Spitsbergen reached their past millennium, and sometimes even Holocene, maxima very recently, at the end of the $19^{\text {th }}$ or early $20^{\text {th }}$ century (e.g. Baeten et al., 2010). Mangerud and Landvik (2007) demonstrated that the outermost moraine of Scottbreen Glacier was deposited about CE 1900 and overlies a marine shoreline dated to 9250 BCE. This indicates that over the Holocene the glacier was never more extensive than it was at the turn of the 20th century. Liestøl (1988) estimated that the equilibrium-line altitude 
depression $(\triangle E L A)$ driving the recent maximum in Spitsbergen was about $100 \mathrm{~m}$, although the lake sediment reconstruction provides more restricted estimates between 40 to $50 \mathrm{~m}$ (Røthe et al., 2015).

\subsection{Scandinavia}

Karlén (1988) and Karlén and Kuylenstierna (1996) recognized several Holocene advances in Scandinavia around CE >1, 100-400, 800-1000, and 1300-1800. This chronology was based on historical, lichenometric, and dendrochronological moraine data, tree-line variations, and lacustrine sediments. The record shows that in Swedish Lapland, glaciers most likely attained their greatest past millennium extent between the 17th and early 18th centuries. Rosqvist et al. (2004) used sediments in Lake Vuolep, Allakasjaure to suggest periods of advanced glacier positions at CE 200, and during the past 1300 years, with a maximum in CE 1700-1800. In southern Norway, Matthews and Dresser (2008) indicated that the most prominent Neoglacial maxima during the past two millennia were centered at intervals CE 100-400, 600-700, 900-1000, 1200-1300, and 1600-1800.

Data from glacier-fed lakes provide continuous histories of glacier variations during the past two millennia. Records of glacial activity from upstream catchments, have been compiled from Northern Folgefonna (Bakke et al., 2005b), Grovabreen (Seierstad et al., 2002), Jostedalsbreen (Nesje et al., 1991, 2001; Vasskog et al., 2012), Spørteggbreen (Nesje et al., 2006), Breheimen (Shakesby et al., 2007), Jotunheimen (Matthews et al., 2000; Matthews and Dresser, 2008), Austre Okstindbreen (Bakke et al., 2010), Lyngen (Bakke et al., 2005a), Langfjordjøkelen (Wittmeier et al., 2015), and Northern Sweden 
(Rosqvist et al., 2004). The composite record (Fig. 2 A) indicates that glaciers in Scandinavia were in an advanced state between CE 200-300, 600-700, 800-1000, and 1500-1800, whereas they were in a retracted state during CE 1-200 (Roman Period), 300$600,700-800,1000-1500$, and during the 19th-20th centuries.

Lichenometric dating and historical evidence indicate that the timing of the past millennium maximum position of outlet glaciers for ice caps and valley glaciers in southern Norway varied considerably, ranging from the early 18th to the late 19th century (Bickerton and Matthews, 1993). Differences in glacier hypsometry, frontal time lag, and responses to climatic parameters (e.g. winter precipitation and summer temperature) may explain the differences in the timing (e.g. Aa, 1996; Nesje, 2005; Nesje et al., 2008). The majority of dated terminal moraines in southern Norway cluster around CE 1740-50, 1780-90, 1860-70, and 1920-40 (Nesje et al., 2008). However, on decadal-scale these variations in southern Norway do not show a consistent regional pattern (Bickerton and Matthews, 1993; Winkler et al., 2003; Matthews, 2005). This is because glacier mass balance measurements show that the annual (net) mass balance of maritime glaciers in western Norway is mostly controlled by winter precipitation, while continental glaciers best correlate with the summer temperature (e.g. Nesje et al., 1995 b; Mernild et al., 2014; Trachsel and Nesje, 2015).

\subsection{Russian Arctic}

\subsubsection{Novaya Zemlya}


Marine sediment cores from Russkaya Gavan' (NW Novaya Zemlya) where the outlet of Shokal'ski Glacier terminates show that between CE 1170 and 1400 Shokal'ski Glacier was in a contracted position and was contributing limited sediment to the fjord (Murdmaa et al., 2004; Polyak et al., 2004). An advance occurred around CE 1400, and between CE $\sim 1470$ and $\sim 1600$ the glacier front was relatively stable before major glacier retreat started. Based on the grain sizes of marine sediments Zeeberg et al. (2003) suggest another advance between CE 1700 and 2000, most likely in the 19th century.

No local high - resolution records are available in Novaya Zemlya, however, the most prominent advance around CE 1400 occurred during an interval of increased winter precipitation and higher cyclonic activity over the North Atlantic as interpreted from ion content in the GISP-2 ice-core record (Zeeberg and Forman, 2000; Meeker and Mayewski, 2002; Murdmaa et al., 2004). The advance in the $19^{\text {th }}$ century may also have been forced by an increase in winter precipitation. This later advance also corresponds with low summer temperatures as indicated by tree-ring reconstruction of June-July temperature from northwest Siberia (Briffa et al., 2013) (Fig. 2).

\subsubsection{Franz Josef Land}

Our understanding of the fluctuations of glaciers on Franz Josef Land is based on a large collection of ${ }^{14} \mathrm{C}$ ages (details are provided in the SM Table 1) constraining positions of 16 glaciers relative to $1991-1995$ (Lubinski et al., 1999). The ${ }^{14} \mathrm{C}$ date on in situ moss at the Glacier B margin (Southern Hall Island) indicates an advance at 409 BCE - CE 223. These data also indicates that the glacier was never less extensive than today over the past 2000 years. At Sonklar Glacier (Southern Hall Island) a lateral moraine is dated to CE 
718-885 by a shell sample either overlain by or incorporated inside the moraine. Yuri Glacier advanced $1.5 \mathrm{~km}$ beyond its 1990 margin around CE 778-1021 and receded prior to CE 1191-1285. At Cape Lagerny (Northbrook Island) the glacier was beyond the present margin until at least CE 545-671. Moss found in situ at the present margins and killed by advances of glaciers dates back to CE 1054-1256, 1519-1950, 1646-1950, and 1684-1928 at Sedov Ice Cap (Western Hooker Island), CE 975-1145 at Cape Lagerny Glacier, CE 1487-1641 at Leight Smith Island, and to CE 1651-1950 at Cape Flora Glacier. Based on these ${ }^{14} \mathrm{C}$ dates and the geomorphology Lubinski et al. (1999) identified glacier advances during the $\sim 10^{\text {th }}$, and $12^{\text {th }}$ centuries, at CE 1400,1600 , and in the early 20th century. Between major advances some glaciers were smaller than at the end of the 20th century. The ice expansion that occurred around CE 1000 was the most prominent in the past two millennia (Lubinski et al., 1999; Forman and Weihe, 2000).

An ice core from Windy Dome provides information on accumulation and summer temperature (melt features) for CE 1225-1997 (Henderson, 2002) (see Fig. 2). The advance that started at the end of the 19th century coincides with high accumulation rates. Unfortunately the precision of the radiocarbon dates is not enough for direct comparison of the time of other advances with the high-resolution ice core records.

\subsection{Northern Asia}

\subsubsection{Kamchatka}

Many glaciers in Kamchatka are located on active volcanoes and therefore are strongly impacted by volcanic activity (Vinogradov et al., 1985; Barr and Solomina, 2014), which 
has to be taken into account when interpreting Kamchatka glacier fluctuations. Historical data, tephrochronology, lichenometry and, to a limited extent, tree rings were used to date moraines in Kamchatka (Barr and Solomina, 2014). Several glaciers record advances of up to $4 \mathrm{~km}$ in length in the first millennium $\mathrm{CE}$, but tephrochronological dating of moraines is still very broad. Bilchenok Glacier (surging in the 1960s) advanced beyond its present limit around 2000 and 1000 years ago. These estimates are constrained by ages of tills found between tephra layers $\sim 600$ BCE and $\sim$ CE 200 and between CE $~ 700$ and 1100, respectively (Yamagata et al., 2002). According to tephrochronology, the West Ichinsky Glacier advanced between CE 200 and 600. Two moraines of Koryto Glacier were formed between CE 700 and 1864, most likely around CE 1000 (Yamagata et al., 2000, 2002) and at Kozelsky glacier one moraine was deposited shortly before CE 1737 (Solomina et al., 1995).

In many cases the most prominent moraines in Kamchatka are ice cored and were deposited during, and often towards the end of, the 19th century. These advances broadly correspond to the greatest accumulation values at CE 1810-1860 recorded in the Ushkovsky ice core (Solomina et al., 2007; Sato et al., 2013).

Tephrochronology, lichenometry, tree-ring dating of moraines and instrumental records of Koryto Glacier in the maritime region of Kronotsky Peninsula indicate advances at CE $1610,1720,1770-1780,1805-1820,1830-1845,1855-1875,1890-1906,1912-1926$, 1954-1957, 1970-1976, and in the mid-1980s, which generally correspond to periods of low summer temperature reconstructed from tree-rings (Solomina and Calkin, 2003; Dolezal et al., 2014). However, the role of winter precipitation for mass balance of 
glaciers in Kamchatka is also very important (Vinogradov et al., 1985). As it was shown by numerical experiments (Yamagichi et al., 2008), the retreat of Koryto Glacier since the mid-20th century was likely due to decreasing winter precipitation.

\subsubsection{Altay}

The collection of ${ }^{14} \mathrm{C}$ dates of wood at glacier forefields in the Altay Mountains is very large, though most were not in situ and the relationship between the wood samples and glacier variations is difficult to interpret. Agatova et al. (2012) suggest that glacier advances similar in extent to those of the 17 th $-19^{\text {th }}$ centuries occurred between $300 \mathrm{BCE}$ and CE 300, although the evidence for these advances is not strong. Nazarov (personal communication, see SM Table 1) reports ${ }^{14} \mathrm{C}$ ages on wood related to advances of Masshey (CE 433-595) and Mensu (CE 435-767) glaciers roughly corresponding to the strong "Late Antiquity Little Ice Age" cooling occurring from CE 536 to around CE 660 in the Altay and the European Alps (Buntgen et al., 2016).

Wood found above the upper modern tree line of Aktru, Maashey and Shavla glacier valleys indicates that glaciers in the Altay were probably in retracted positions between the $8^{\text {th }}$ and $12^{\text {th }}$ centuries (Agatova et al., 2012).

The number of trees damaged by glacier advances between CE 1200 and CE 1800 is high, and ages cluster in the following periods: CE 1200-1260 (3 ages from 3 valleys), CE 1320-1380 (4 ages from 3 valleys), CE 1440-1510 (5 ages from 3 valleys), and CE 1640-1740 (8 ages from 5 valleys) (Nazarov and Agatova, 2008; Nazarov et al., 2012; Agatova et al., 2012) (see also table 1 in SM). Moraines deposited between CE 1640 and 
1740 mark the maximum advance of the past millennium in the Altay region. Since then less prominent re-advances occurred shortly before CE 1835 (Belukha region), in the mid and late $19^{\text {th }}$ century and the early $20^{\text {th }}$ century.

A 2367-year-long tree-ring chronology sensitive to early summer temperature from the Altay region (Myglan et al., 2012a,b; Buntgen et al., 2016) shows that glacier advances of the middle of the first millennium and from the 15th to 19th centuries generally coincide with cool summers (Figure 2).

\subsection{European Alps}

The glacier record for the European Alps over the past two millennia is mainly based on calendar-dated tree-ring series for the early periods and on historical documents from $\mathrm{CE}$ 1600 onwards. Additionally, for many glaciers there are continuous length measurements available for the past 130 years.

The first centuries CE were characterized by retracted glacier termini. Some evidence is available that at least some glaciers (e.g., Great Aletsch and Steinlimni in the Swiss Alps) were as small as they were during the late 20th century (Holzhauser et al., 2005; Joerin et al., 2006). Sediments in glacial meltwater-fed Blanc Huez (Western French Alps) indicate reduced glacier activity in its catchment (Simonneau et al., 2014) in the first centuries CE. Archeological artefacts, collected at the Schnidejoch pass, a glacier pass in the Bernese Alps (Switzerland) that could hardly be crossed in periods of large ice extent, span much of the first millennium $\mathrm{CE}$, however, and show the highest activity during the Roman period and indicate the relatively intensive use of this crossing (Grosjean et al., 
2007; Hafner, 2012). Glacier advances in the Alps are recorded as early as CE 270 and 335 (Nicolussi and Patzelt, 2001; Holzhauser et al., 2005). Ice during the 5th century was as extensive as the late 20th century for Glacier du Trient (Hormes et al., 2001) and around CE 410 for Great Aletsch Glacier (Holzhauser et al., 2005), both in the Swiss Alps.

Significant advances in the 6th century at Great Aletsch, Lower Grindelwald, Gorner, and Mer de Glace glaciers (Swiss and French Alps) culminating at the end of that century or in the early $7^{\text {th }}$ century brought these ice masses to their maxima in the western and central Alps during the first millennium CE (Holzhauser et al., 2005; Le Roy et al., 2015). A persistent advance phase during this period, from the 5th to the 9th century, is also reconstructed for the Miage Glacier Glacier (Italian Alps) (Deline and Orombelli, 2005). However, evidence for the 6th century advance is less clear in the eastern Alps (Gepatsch Ferner and Sulden Ferner) and does not indicate extents comparable to the 19th century (Nicolussi and Patzelt, 2001; Nicolussi et al. 2006). Sulden Ferner (Italy) was shorter than in the 19th century between CE 400 and 800. At Unteraar Glacier (Switzerland), the ice extent during the $8^{\text {th }}$ century was as small as during the late 20th century (Hormes et al., 2001). An advance phase during the 9th century is evident at Gepatsch Ferner and Lower Grindelwald glaciers, but is less well constrained at Great Aletsch and Gorner glaciers (Nicolussi and Patzelt, 2001; Holzhauser et al., 2005). At the Sulden Ferner, an advance at CE 835 nearly reached the $17^{\text {th }}-19^{\text {th }}$ centuries' margins (Nicolussi et al., 2006). In the eastern Alps, the CE 835 advance was probably the most far reaching during the first millennium CE. General retreat of glacier termini can be deduced for the late 9th to 11th centuries. Reduced glacier activity at this time is also suggested by the sediment 
record of Lake Blanc Huez (Simonneau et al., 2014), and the youngest artefacts from Schnidejoch indicating that it was possible to cross the pass at that time (Hafner, 2012).

A subsequent glacier advance occurred in the 12th century (e.g., Gepatschferner, Gorner and Mer de Glace; Nicolussi and Patzelt, 2001; Holzhauser et al., 2005; Le Roy et al., 2015). After a short retreat phase, a general advance is documented in the late 13th century that culminated between CE 1350 and 1385 at Great Aletsch, Gorner, Mer de Glace, and Vernagtferner (Austria) glaciers (Holzhauser et al., 2005; Patzelt, 2013; Le Roy et al., 2015). This advance was less extensive at Gepatschferner and Pasterze (Austrian Alps) (Nicolussi and Patzelt, 2001). Glaciers retreated by CE 1400 but further advances are recorded later in the 15th (Gepatschferner, Stein, and Tsidjiore Nouve glaciers; Austrian and Swiss Alps) and early $16^{\text {th }}$ centuries (Great Aletsch and Tsidjiore Nouve glaciers) (Nicolussi and Patzelt, 2001; Holzhauser et al., 2005; Schimmelpfennig et al., 2012; 2014).

The most widespread phase of glacier advances in the Alps (CE 1600 to 1860) is characterized by a series of advances during which generally similar extents were reached: 1600, 1640, 1680, 1720, 1775, 1820 and 1855/60 (e.g., Zumbühl et al., 1983; Nicolussi and Patzelt, 2001; Grove, 2004; Deline and Orombelli, 2005; Holzhauser et al., 2005; Nicolussi et al., 2006, Nussbaumer et al., 2007; Ivy-Ochs et al., 2009; Imhof, 2010; Nussbaumer and Zumbühl, 2012; Schimmelpfennig et al., 2012; 2014; Patzelt, 2013; Le Roy et al., 2015). However, the number of maxima, the ages of the advances and the similarity of extents vary and were controlled mainly by the dynamics of each glacier system. 
General retreat began after 1860 and was interrupted by re-advances around 1890, 1920 and 1980. However, some glaciers, e.g., Great Aletsch Glacier (Holzhauser et al., 2005), have retreated continuously since their mid-19th century maxima (Zemp et al., 2008).

Mass balance variability in the Alps mainly correlates with summer temperature, while winter precipitation usually plays a less important role (e.g., Vincent et al., 2005; Steiner et al., 2008). A summer temperature reconstruction (Büntgen et al., 2011) based on treering width data from the eastern Alps (Nicolussi et al., 2009) is in very good agreement with the high resolution glacier records supporting summer temperature as the primary control on glacier fluctuations.

\subsection{Caucasus}

There is no evidence of glacier variations in the first millennium in the Caucasus. Glaciers were probably small in the beginning of the past millennium, but the available evidence is only indirect (archeological, biostratigraphic and pedological data) (Solomina et al., 2016). Serebryanny et al. (1984) reported a minimum ${ }^{14} \mathrm{C}$ age for a moraine in the Bezengi Valley (CE 1245-1428). However taking into consideration the location of this moraine relative to the modern glacier $(6 \mathrm{~km})$ the age obtained from a peat bog within the moraine complex is probably too young to closely constrain the age of the moraine. At Bol'shoy Azau Glacier a radiocarbon age of a soil horizon buried between two glacial units dates to CE 1465-1642 (Baume and Marcinek, 1998). Trees growing on this surface are more than four hundred years old, suggesting that the age of the upper glacial unit and of the corresponding glacial advance is at least CE 1600. 
According to tree-ring minimum dates Bol'shoy Azau Glacier advanced prior to CE 1598 and Kashkatash Glacier before CE 1600 (both are located in the Elbrus area). A younger advance in the mid-19 $9^{\text {th }}$ century reached almost the same extent at both glaciers (Solomina et al., 2016). Two other major advance phases in the Northern Caucasus date back to the second half of $17^{\text {th }}$ century and the first half of the 19th century (minimum tree-ring ages at Tsei Glacier) (Solomina et al., 2016). General glacier retreat started in the late 1840s. Four to five minor readvances occurred in the period between CE 1860s and 1880s and three readvances or still stands took place in 1910s, 1920s and 1970s1980s. A reconstruction of June-September temperature in the Central Caucasus based on blue intensity (equivalent of maximum density) from conifers spans the period CE 15692008 (Dolgova, 2016), and the glacial advance of the 1840s coincides with a reconstructed cold period (CE 1825-1867).

\subsubsection{Central Asia, semi-arid area}

Compiling and evaluating ${ }^{10} \mathrm{Be}$ ages, Dortch et al. (2013) recognized late Holocene advances in the semi-arid western end of the Himalayan-Tibetan Orogen at CE $400 \pm 300$ and CE 1600 \pm 100 CE. At Abamova Glacier (Pamir-Alai Mountains) a radiocarbon age from a shallow soil horizon below a fresh till (CE 903-1188) indicates a glacier advance shortly after this date (Zech et al., 2000). Wood found in a buried soil horizon at Raigorodskogo Glacier (Pamir-Alai Mountains) provides evidence of a warm period and glacier retreat shortly before CE 255-527 when the glacier expanded (Narama, 2002). The youngest advance is dated by a ${ }^{14} \mathrm{C}$ age (CE 1521-1646) on a trunk of Juniperus turkestanica broken by a glacier advance. These two advances were of similar magnitude, 
although the former was slightly larger. Historically, advances of Raigorodskogo Glacier are recorded back to CE 1908-1934, and CE 1960-1977 (Narama, 2002). In the Urumchi valley (Tien Shan) samples of whewellite coating on glacial boulders from the outermost moraines indicate that the glacier retreated from its maximum extent before $\mathrm{CE}$ $1535 \pm 120$.

\subsection{Central Asia, monsoon area}

Röthlisberger and Geyh (1985) undertook some of the first studies using radiocarbon ages from glaciers in Pakistan, India, and Nepal to show that glaciers advanced at CE 250-550, 650-1050, $1150-1400$ and $1450-1850$. Using ${ }^{10} \mathrm{Be}$, Murari et al. (2014) identified three advances in the monsoon-influenced Himalaya-Tibetan area at $\mathrm{CE}$ $500 \pm 200,1300 \pm 100$ and $1600 \pm 100$. For the same area, Yang et al. (2008) established a chronology for the past two millennia based on multi-proxy data and recognized three main periods of glacier advance at around CE 200-600, 800-1150, and 1400-1920, with the most widespread glacier advance occurring at about CE 400-600 (Fig. 2). They suggested that these advances were synchronous with those in the southern Himalaya during CE 380-600, 870-1100, 1400-1430, and 1550-1850, and that the glacier advance around CE 1000 also occurred in the central Himalaya. Xu and Yi (2014) reported that glaciers retreated from their maxima during the 16 th to early 18 th, late 14 th to early 15 th and early 16th centuries in the southern, northwestern, and northeastern regions, respectively. In addition, they suggested that the periods of glacier advance during the late 18th to early 19th centuries and the retreat period of the late-19th century are common throughout Tibet. 
Dendrochronological dating provides higher precision ages for glacier advances in Tibet, which occurred before the 15th century, before 1662, between1746 and 1785 (maximum extent), early 19 th, late 19 th to early $20^{\text {th }}$, and during the mid-20th centuries (Brauning, 2006; Zhu et al., 2013; Xu et al., 2012; Hochreuther et al., 2015; Loibl et al., 2015). On a centennial (Yang et al. 2003, 2008; Xu and Yi, 2014) and decadal (Wang et al., 2015) timescale, temperature changes are the main controlling factor for glacier fluctuations rather than precipitation changes caused by variations in the south Asian summer monsoon. Tree-ring studies for the western Himalaya show that the 18th and 19th centuries were the coldest interval of the past millennium coinciding with the expansion of glaciers in the western Himalaya (Yadav et al., 2011).

The $\triangle$ ELA for Zepu Glacier (S-E Tibetan Plateau) estimated from moraines deposited at CE $200-600,800-1150,1400-1650$, and the $19^{\text {th }}$ century was $160 \mathrm{~m}, 110 \mathrm{~m}, 60 \mathrm{~m}$, and $10 \mathrm{~m}$, respectively, which is equivalent to temperature lowering of $1.0^{\circ} \mathrm{C}, 0.7^{\circ} \mathrm{C}, 0.4^{\circ} \mathrm{C}$ and $0.1^{\circ} \mathrm{C}$ compared to 1989 (Yang et al., 2008). In most areas of Central Asia, glaciers began and continue to retreat since the beginning of the 20th century (Mayewski and Jeschke, 1979; Mayewski et al., 1980; Kutuzov and Schakgedanova, 2009; Owen and Dortch, 2014).

\subsection{Low latitudes}

Ninety-five percent of tropical glaciers are located in the Andes. A collection of 14C dates constraining mostly minimum or maximum ages of glacier advances in the tropics of South America is available (e.g. Mercer and Palacios, 1977; Claperton, 1983; Goodman et al., 2001; Rodbell et al., 2009), though only recent development of TCN 
dating made it possible to describe the Late Holocene history of some glaciers (mostly in the outer tropics) in sufficient details (Licciardi et al., 2009; Hall et al., 2009; Jomelli et al., 2011, 2014; Stroup et al., 2014, 2015 - recalculated in this study using the regional mean production rate from Martin et al., 2015 and Lal/Stone scaling scheme). Lake sediment studies (Abbot et al., 2000; Polissar et al., 2006; Rodbell et al., 2008; Stansell et al., 2014) provided a continuous context useful for the interpretation of the moraine ages.

In the outer tropics accumulation occurs only during the wet period, whereas in the inner tropics it lasts the whole year (Kaser and Osmaston, 2001). Here we consider the two regions separately.

\subsubsection{Inner tropics}

According to lake sediment records from the Venezuelan Andes (Polissar et al., 2006) glaciers in the Mucubají watershed were absent between CE 500 and 1100 and since the 1820s, but four glacial advances occurred in the second millennium (1180-1350, 14501590, 1640-1730, and 1800-1820. In the same region Stansell et al. (2014) documented glacier changes in two other catchments. At low elevation $(<4400 \mathrm{~m}$ asl) lake sediment do not show any signal of glacier advance during the last centuries while a in the catchment located at a higher altitude $(4750 \mathrm{~m})$ the increase of clastic sediments indicate the glacial activity during the period between CE 1350 to 1850 .

On the southern slope of the Cordillera del Cocuy (Colombia) two moraines of Ritacuba Negro Glacier were dated by TCN to CE $900 \pm 90$ and CE $1750 \pm 30$ (recalculated from Jomelli et al., 2014). Using historical data, Hastenrath (1981) demonstrated that 
glaciation in the Ecuadorian Andes, near Quito, was more extensive at the time of the Spanish conquest in the 16 th century than in the late $20^{\text {th }}$ century.

In the inner African tropics Karlen et al. (1999) identified periods of glacier advances at Mount Kenya from lake sediments for CE 400-750, around 1350 and around 1550, while retreat phases occurred between $150 \mathrm{BCE}$ and CE 400 and in CE 750-850. In the 1890s the glaciers on Mt Kenya were still close to their prominent moraines. Comparing the glacier records with the paleoclimatic information Karlen et al. (1999) attributed the glacier advances primarily to changes in temperature.

\subsubsection{Outer tropics}

Rodbell (1992) identified the culmination of clastic sediment flux in Laguna Queshque, Cordillera Blanca, at $\sim \mathrm{CE} 500$ corresponding to the ${ }^{14} \mathrm{C}$ date of a moraine deposited in a nearby cirque in CE $450+/-190$. Abbot et al. (2000) demonstrated that the glacial activity in Lago Taypi Chaka Kkota, Cordillera Real, Bolivia, was gradually increasing from $\sim 300 \mathrm{BCE}$ and reached the modern level around $\sim \mathrm{CE}$ 500-600. Stansell et al. (2013) reported that clastic sediment flux was low in the deposits of proglacial lakes in southern Peru from $\sim 4.0$ ka to 14 th century CE, indicating that the glaciers were generally in retreated positions.

At some glaciers the peak of glacial activity occurred in the late $17^{\text {th }}$ through $18^{\text {th }}$ century. In Cordillera Real, Bolivia, the TCN samples from Telata glacier show an advance at CE $1760 \pm 130$ (Jomelli et al., 2011). Using the TCN Hall et al. (2009) dated an advance of Miticocha glacier to CE $1740 \pm 30$ in Cordillera Huayhuash. Licciardi et al. (2009) 
identifed the moraines deposited around the same time at three glaciers (Salcantay - CE

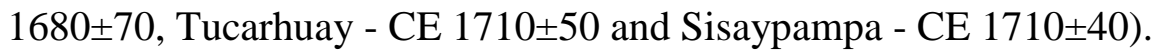

The most robust reconstruction of glacier and climate variations in the outer tropics comes from the Quelccaya Ice Cap (Peru). Here there are evidence of earlier glacier advances. Five successive moraines at Qori Kalis Glacier were formed at CE 1500 \pm 20 , $1635 \pm 20,1685 \pm 20,1705 \pm 10$, and 1795 \pm 10 (recalculated from Stroup et al., 2014, 2015). Comparing the time of Qori Kalis Glacier advances and the Quelccaya Summit Dome ice core records (Thompson et al., 2013) Stroup et al. (2014) deduced that temperature rather than accumulation was the main driver of glacier changes. In the 20th century tropical glaciers are retreating at faster rates than in other mountain regions of the World (Rabatel et al., 2013).

\subsection{Dry Andes}

Extremely limited information on glacier fluctuations during the past two millennia is available in the Dry Andes between $17^{\circ}$ and $36^{\circ} \mathrm{S}$. No ages are available for the first millennium, but ${ }^{14} \mathrm{C}$-dated peat samples and paleosols date maximum expansion of the past millennium to the 16th-17th centuries (Espizua and Pitte, 2009; Masiokas et al., 2009a; Table 1 Supplementary Materials and Fig. 2). Additional limited evidence indicates subsequent re-advances during the 19th century. During the general retreat of the past decades, numerous frontal re-advances and surging events have been identified, mostly in the past 30-40 years (Masiokas et al., 2009a). 


\subsection{Southern South America (Patagonia, Tierra del Fuego)}

In the North Patagonian Andes (ca. $36^{\circ}-45^{\circ} \mathrm{S}$ ) no ages are available for glacier advances during the first millennium. Maximum extents of the past millennium occurred between the 16th and 19th centuries as indicated by tree-ring dated moraines and ${ }^{14} \mathrm{C}$ dating of in situ stumps affected by advancing glaciers (e.g. Villalba et al., 1990; Masiokas et al., 2010; Ruiz et al., 2012; see Table 1SM).

Further south at the latitudes of the Northern Patagonian Icefield (NPI; $46^{\circ}-47^{\circ} \mathrm{S}$ ), in situ roots of trees killed by the advancing Soler Glacier and found in front of it were ${ }^{14} \mathrm{C}$ dated to between the 13th and 14th centuries and provide one of the best indicators of early glacier activity in this region (Glasser et al., 2002). Tree-ring and lichenometric dating of trimlines and moraines of several NPI outlet glaciers indicate that their maxima probably occurred during the 19th century (Winchester and Harrison, 1996; Harrison and Winchester, 1998, 2000; Winchester et al., 2001; Harrison et al.., 2007, 2008; Glasser et al., 2011).

${ }^{14} \mathrm{C}$ dating of in situ and reworked stumps and ${ }^{10} \mathrm{Be}$ dating of boulders on moraine crests from several sites around the Southern Patagonian Icefield (SPI; $49^{\circ}-51^{\circ} \mathrm{S}$ ) show a period of glacier advances between the 4th and 9th centuries (e.g. Mercer, 1965; Rothlisberger 1986; Aniya 2013; Strelin et al., 2014). Numerous in situ trees killed by Ameghino Glacier (an eastern outlet of the SPI) and Glaciar Jorge Montt (northern tip of the SPI) during its main advance between the $15^{\text {th }}$ and $17^{\text {th }}$ centuries were up to 300 years old indicating smaller glaciers and likely warmer conditions, however, the size of the glaciers at that time is not known (Masiokas et al., 2009a). There is however also a growing body 
of evidence for glacial advances between the 13th and 15th centuries (e.g. Mercer, 1970; Rothlisberger 1986; Strelin et al., 2014). In this portion of the Andes the maximum expansion has been dated between the 17th and 19th centuries largely based on dendrochronological determinations and ${ }^{14} \mathrm{C}$ dating of in situ stumps and paleosoils (e.g. Mercer, 1965, 1970; Rothlisberger, 1986; Aniya, 1995, 2013; Aravena, 2007; Masiokas et al., 2009b; Aniya and Skvarca, 2013; Strelin et al., 2014; Glassser et al., 2011). Despite several re-advances identified in the past century, glacier recession has been clearly evident both in northern and southern Patagonia and it has apparently accelerated in recent decades (Rignot et al. 2003, Masiokas et al. 2009a; Glasser et al., 2011).

The evidence in the Magallanes-Tierra del Fuego region indicates a similar pattern to that observed around the South Patagonian Icefield, with glacier advances around the 8th century, around the 14th century, and maxima between the 17th and 19th centuries (Kuylenstierna et al., 1996; Koch and Killian, 2005; Aravena, 2007; Strelin and Iturraspe, 2007; Strelin et al., 2008). The earliest ages are based on ${ }^{14} \mathrm{C}$ dating of reworked stumps whereas the later events are largely based on tree-ring dating of deposits. Glacier readvances during the 19th and 20th centuries have also been identified and dated using tree-rings and direct observations (Kuylenstierna et al., 1996; Koch and Killian, 2005; Aravena, 2007; Strelin et al., 2008). Glaciers in the Cordillera Darwin show a contrasting behavior in the late 20th century, with glaciers reaching positions at or close to their Holocene maxima in the southern and western flanks and showing marked frontal retreats on the northern and eastern flanks of the Cordillera (Holmlund and Fuenzalida, 1995; Porter and Santana, 2003). Glaciers in the Cordillera Fueguina Oriental (at almost $55^{\circ} \mathrm{S}$ ) probably reached their past millennium maximum between the 16 th and 17 th centuries 
and receded slowly until $\sim 60-70$ years ago, when the rate of glacier retreat accelerated (Strelin and Iturraspe, 2007).

Moreno et al. (2014) reconstructed centennial changes in southern South American climate over the past three millennia based on a stratigraphic record collected around $51^{\circ} \mathrm{S}$. This reconstruction is particularly relevant because it reproduces well the patterns of the Southern Annular Mode (SAM), the main driver of atmospheric variability in the mid- to high-latitudes of the Southern Hemisphere. In their reconstruction, Moreno et al. (2014) identified two periods of cold/wet conditions in southern Patagonia peaking at around CE 250-350 and CE 550-850 CE. Although the evidence for glacier advances in this region is limited for the first millennium, these cold/wet intervals seem to correspond with the few events identified during this period in Patagonia and Tierra del Fuego (Fig. 2). Glasser et al. (2004) claim that the advance of Soler in CE 1220-1340 and of four other glaciers in Southern Patagoina corresponds to the increase of winter precipitation. Hoewever overall the period of extensive glacier advances between the 13th and 19th centuries coincides with an extended cold/wet interval. This extended period of glacier advances is also correlative with a long-term cool/wet interval identified in marine sediment records at around $44^{\circ} \mathrm{S}$ along the north Patagonian coast (Sepulveda et al., 2009). Several studies have noted a general warming in southern South America during the $20^{\text {th }}$ century (Villalba et al. 2003; Masiokas et al. 2008; Neukom et al., 2010), and Moreno et al. (2014) corroborate these previous studies showing a dramatic change towards warm/dry conditions starting in the late $19^{\text {th }}$ and early $20^{\text {th }}$ centuries (Fig. 2). 


\subsection{New Zealand}

Recent glacier recession in the Southern Alps of New Zealand has led to the exposure of soils and wood buried within steep lateral-moraine walls. ${ }^{14} \mathrm{C}$ ages on organics associated with these soils afford age constraints on underlying and/or overlaying tills (Burrows, 1973; Röthlisberger and Geyh, 1986, Gellatly et al., 1988; Grove, 2004) (see SM table). According to these data the most extensive advances in New Zealand occurred around 1000 and 600 years ago and in the 19th century (Gellatly et al., 1988). In addition, Wardle (1973) counted rings of trees living on moraine ridges to place minimum-limiting ages on late Holocene moraine deposition by glaciers draining the western flank of the Southern Alps. He determined that eighteen Westland glaciers constructed moraines during, or prior to, the mid- to late- $18^{\text {th }}$, the early- to mid-19th, and the late 19 th centuries.

Recently, longer and more detailed moraine chronologies from four glacier systems have been constructed using ${ }^{10} \mathrm{Be}$ surface-exposure dating at Mueller, Tasman, Hooker Glaciers near Aoraki/Mount Cook (Schaefer et al., 2009) and Cameron glacier in the Arrowsmith Range (Putnam et al., 2012) in the central Southern Alps. These results compare remarkably well with previously obtained and recalibrated radiocarbon dates (arithmetic means with $1 \sigma$ uncertainty from the ${ }^{14} \mathrm{C}$ ages, when referenced to the same year as exposure ages).

At Mueller Glacier, the outermost Late Holocene lateral moraine was deposited in 1410 $\mathrm{BCE} \pm 150$, and inboard moraines were constructed at $380 \mathrm{BCE} \pm 100,135 \mathrm{BCE} \pm 100$, CE $150 \pm 100$, CE $1390 \pm 80$. Results reported here are those of Schaefer et al. (2009) as recalculated by Putnam et al. (2012) using the local New Zealand production rate of 
Putnam et al. (2010). The most prominent moraine of the past millennium was constructed by CE $1540 \pm 80$ yrs, with moraines being constructed at positions slightly inboard at CE $1715 \pm 60, \mathrm{CE} 1754 \pm 8$, and CE $1824 \pm 31$ yrs.

At Hooker Glacier, the sequence of lateral moraine ridges were constructed by CE $430 \pm$ 220 and CE $860 \pm 100$ yrs. At Tasman Glacier, the distal moraine was deposited CE 146 \pm 100 , whereas a proximal moraine was formed contemporeously with the one at the Hooker Glacier CE 860 (Schaefer et al., 2009; Putnam et al., 2012).

At Cameron Glacier moraines deposited during the past two millennia are fewer, with moraines dated to CE $1298 \pm 27$ and CE $1427 \pm 61$ that are adjacent to much older (4940 $\mathrm{BCE} \pm 190$ ) moraine surfaces. Progressive retreat of the glacier terminus since the 15th century was interrupted by stillstands or minor readvances around CE 1770, 1864, and 1930 (Putnam et al., 2012).

Since the 1860 s, the glaciers of New Zealand have been retreating with minor readvances in 1888, 1908-1909, early 1920s, 1947-1950, 1965-1967 and 1980-2005. There has been net recession since the 1940s (Purdie et al., 2014), however a period of stable mass balance and glacier readvance/stillstand registered widely across Southern Alps glaciers interrupted this trend between CE 1980 and CE 2005 (Chinn et al., 2005; Purdie et al., 2014). This general pause in ice retreat and snowline rise has been suggested to relate to a switch in the phase of the Interdecadal Pacific Oscillation (IPO) that occurred around CE 1978, which involved an increase in the proportion of cold air mass incursions to the Southern Alps from southerly quarters during the ablation season (Tyson et al., 1997). Atmospheric warming and renewed glacier retreat beginning shortly after CE 2005 may 
relate to the most recent switch of the IPO (Purdie et al., 2014). Currently, less than a third of the maximum ice volume from around $1850 \mathrm{CE}$ remains (Chinn et al., 2012).

The magnitude of advances in the past two millennia in the Southern Alps of New Zealand varied from glacier to glacier, but in general it was decreasing over the past millennium. However, all moraines formed since the mid Holocene are located very close to one other and to the moraines of 19th century. Due to this similarity in magnitude of glacial advances some of moraines are destroyed and overlain by later advances, leading to the composition of moraine complexes of individual glaciers to be different.

\section{Discussion}

\subsection{What was the magnitude of glacier fluctuations in the past two millennia and is it comparable in scale with contemporary glacier retreat?}

Determining the size of former glaciers that were less extensive than later glacial advances is a challenge due to the paucity of these records. However, there is much evidence that during certain periods of the first millennium glaciers were smaller (or of equal sizes) than they were at the end of the $20^{\text {th }}$ to early $21^{\text {st }}$ centuries in many regions including the Arctic (e.g. Iceland, Spitsbergen, Alaska), temperate zone (e.g. Scandinavia, Altay, Alps, Tibet) and the tropics (e.g. Peru, Bolivia) (see references in Table 2). The extremely rare occurrence of moraines deposited in the first millennium in the Southern Hemisphere and in the tropics also indirectly indicates that generally at that time the climate conditions were less favourable for glaciers than over most of the second millennium excluding the past one to two centuries. In some regions such as Southern 
Alaska, the European Alps and the Altay the glaciers also retreated approximately from the $8^{\text {th }}$ up to the $13^{\text {th }}$ centuries, but the magnitude of their retreat during the MCA is unknown. We found only one clear indication (Røthe et al., 2015) of glacier retreat to close or within their present limit after the $13^{\text {th }}$ century (Spitsbergen around CE 1400 and between CE 1720 and 1810) (see also Fig. 5).

The time of the most prominent advances in the past two millennia varies not only from region to region, but also from glacier to glacier. As described in section 4 (see references therein) in the Alps the maximum extent the glaciers was reached in the $17^{\text {th }}-19^{\text {th }}$ centuries, but advances in the $6^{\text {th }}$ century in the Swiss and French Alps and in the $9^{\text {th }}$ century in the Eastern Alps were of nearly similar magnitude. A maximum glacier advance also occurred in the Alps in the $14^{\text {th }}$ century. In Alaska outboard moraines were deposited in the 1800s, but there are also cases when they were formed in the first millennium or about CE 1300. In the high latitudes the maximum glacier advance often occurred quite late (in the $19^{\text {th }}$-to-early $20^{\text {th }}$ centuries), although recent discoveries indicate advances of similar magnitude dating back to the first millennium-(e.g. in Spitsbergen in CE $350 \pm$ 90; in Greenland in CE 300 and in CE 490). Maxima of glacial advances in the $17^{\text {th }}$-to $18^{\text {th }}$ centuries occurred in the Swedish Lapland, the Altay Mountains and in some regions of the Canadian Cordillera; in the $18^{\text {th }}$ to early $20^{\text {th }}$ century they occurred in Iceland, the Canadian Rockies, and Southern Patagonia. In Central Asia and in the tropics glaciers often reached their maxima in the $15^{\text {th }}-16^{\text {th }}$ centuries. Major advances around CE 1000 occurred in Franz Josef Land and at some glaciers in Central Asia. Mueller Glacier in New Zealand reached its maximum at the beginning of the first millennium, while the maximum advance of Hooker Glacier 
occurred a few centuries later in the $\sim 9^{\text {th }}$ century, and Cameron Glacier reached its maximum extent even later in the $13^{\text {th }}-15^{\text {th }}$ centuries.

During the maximum advances of the past millennium the ELA was lower than at the end of the $20^{\text {th }}$ century in the Alps (Grove, 2004), Norway (Nesje, 2009), the Caucasus, the Altay, Kamchatka (Solomina, 1999), and in the Central Andes of Argentina (Espizua and Pitte, 2009) by $100-150 \mathrm{~m}$. In New Zealand the $\Delta$ ELA from the maximum last millennium extent is about $140 \mathrm{~m}$ (Putnam et al., 2012). The $\Delta$ ELA was much smaller $(10-20 \mathrm{~m})$ in arid Central Asia, while in the tropics of Peruvian Andes it reached as low as $300 \mathrm{~m}$ (Jomelli et al., 2011) and up to 300-500 m in Venezuela (Polissar et al., 2006). On Baffin Island the magnitude of the snowline variations in the past two millennia is estimated to be up to $400 \mathrm{~m}$ (difference between the beginning of CE and the $19^{\text {th }}$ century) (Miller et al., 2013). Unfortunately for most regions we cannot assess the full range of ELA variations over the past two millennia primarily due to uncertainties related to the magnitude of glacier retreat during warm periods.

Globally, the number of advances recorded before the $11^{\text {th }}$ century is much smaller than in the second millennium, but it is still extensive enough to state that in many regions glacier advances occurred during the first millennium as well, and whereas later advances did not destroy some of these moraines, the magnitude of these first millennium advances was rather large and most likely comparable with those of the second millennium. 


\subsection{Ablation-season temperature or accumulation-season precipitation? Climate signal in glacial records of the past 2 millennia}

Glacier mass balance measurements over the historical period demonstrate that for most regions summer temperature is the dominant control on annual mass balance (Koerner, 2005; Bjornsson et al., 2013). Some exceptions when glacier advances were forced primarily by high winter precipitation are recorded in coastal areas of Scandinavia, SE Alaska, Kamchatka and New Zealand (e.g. Lemke et al., 2007). Similarly, over the past two millennia for those regions where summer temperature or both summer temperature and winter precipitation reconstructions are available, and the accuracy of the glacier records allows a resolution of a few decades, lower summer temperatures coincide with many of the recorded ice advances (e.g., Alaska: Wiles et al., 2004; 2008; Barclay et al., 2013; Anchukaitis et al., 2013; Canadian Rockies: Luckman, 2000; Alps: Holzhauser et al., 2005; McCormick et al., 2012; Luethi, 2014; Le Roy et al., 2015; Monsoon Asia: Yang et al., 2008; New Zealand: Schaefer et al., 2009, Neukom et al., 2010; Leclercq et al., 2012; Jomelli et al., 2011; Malone et al., 2015) (see also Fig. 2). In a few cases increased snowfall was suggested as the primary driver of former advances, e.g., in western Norway (Nesje et al., 2007; Bakke et al., 2008; Rasmussen et al., 2010) in the Canadian Rockies (Luckman and Villalba, 2001), during the MCA (Koch and Clague, 2011), in the Brooks Range CE 1600 (Boldt et al., 2015), and in the central Himalaya in the $19^{\text {th }}$ century (Yang et al., 2008).

At a more general level there is some agreement between the temperature reconstructions (PAGES 2 ka consortium, 2013) for the Arctic and Europe, with glacier fluctuations in 
the high and mid latitudes (Fig. 3). This suggests that maximum advances correspond to cooling times. Glacier advances dominated from the mid $13^{\text {th }}$ century, consistent with the transition of the summer temperature regime to cooler conditions (Fig. 3). The advances to the past millennium maximum glacier extents occurred in the $17^{\text {th }}-18^{\text {th }}$ and $19^{\text {th }}$ centuries and generally correspond to the most prominent cooling, at least in the mid and high latitudes of the Northern Hemisphere as reconstructed by the above mentioned PAGES project. The number of glacier advances fits well with the Northern Hemisphere temperature reconstruction based on high and low frequency proxy data (Moberg et al., 2005), especially for the period since the $8^{\text {th }}$ century (Fig. 6). The number of recorded glacier advances continues to increase after the peak of cooling in the $17^{\text {th }}$ century partly due to the well-preserved recessional moraines deposited after the most prominent advances in the $17^{\text {th }}, 18^{\text {th }}$ and $19^{\text {th }}$ centuries.

Modelling based on current mass balance observations and paleoclimatic proxies was used to estimate the climate conditions responsible for the advances over the last two millennia in several regions. Regional estimates of ELA changes in the Alps between the last LIA high-stand in the mid- $19^{\text {th }}$ century and $\sim 1970$, based on glacier extents and ablation-accumulation area calculations, suggests an ELA rise of $\sim 69 \mathrm{~m}$ and $\sim 94 \mathrm{~m}$ for the Swiss (Maisch et al., 2000) and Austrian Alps (Patzelt and Aellen, 1990). A modelled ELA rise of $75 \mathrm{~m}$ calculated on the observed increase in summer temperature between 1850 and $1971 / 90$ of $0.6^{\circ} \mathrm{C}$ meets these values (Zemp et al., 2007). A further rise of the ELA between 1984 and 2010 by about 170 m was established for a group of glaciers in the western Alps (Rabatel et al., 2013 b). This ELA increase in the Alps since the mid$19^{\text {th }}$ century was mainly a result of summer climate change, i.e., mass balance 
reconstructions proved no significant trend for winter balances (Huss et al., 2008). Statistical analyses of mass balance series from the Alps covering the last ca. 60 years also prove the dominance of summer climate variability, i.e., summer temperature and related variables, on the evolution of glaciers (e.g., Schöner and Böhm, 2007).

In the tropical Andes, Rabatel et al. (2008) suggested that the glacier maximum in the $17^{\text {th }}$ century may have been due to a 20 to $30 \%$ increase in precipitation and a 1.1 to $1.2{ }^{\circ} \mathrm{C}$ decrease in temperature compared with the present conditions. Malone et al. (2015) demonstrated that a $1{ }^{\circ} \mathrm{C}$ cooling compared to today (without changes in precipitation) is necessary to explain Qori Kalis' maximum extent at CE $1500 \pm 20$ (reaculated from Stroup et al., 2014). In Venezuela, Polissar et al. (2006) assessed that a 300 to $500 \mathrm{~m}$ lowering of the ELA occurring between CE 1250 and CE 1820 is equivalent to a 2.6 - 4.3 ${ }^{\circ} \mathrm{C}$ drop in temperature, assuming constant annual precipitation. By combining these results with a biome migration index, they advocated for a $3.2 \pm 1.4^{\circ} \mathrm{C}$ cooling and a $22 \%$ increase of precipitation. Leclercq et al. (2012) calculated that the retreat of Frias Glacier in Northern Patagonia in CE 1639-2009 could be best explained by a $1.2{ }^{\circ} \mathrm{C}$ warming. 
Finally, it has to be stressed that glaciers react in a complex manner to both temperature and precipitation, and in many cases the data are still too scarce to assess the respective role of temperature and precipitation changes on glacier fluctuations. The weight that both parameters contribute to mass balance changes is specific for each glacier.

\subsection{What were the periods of major glacier advances and retreats in key mountain regions over the last 2 millennia, and how synchronous were they regionally and globally?}

Below we summarize the information on glacier advances from regional reviews as well as from the best-dated individual series of glacier variations in chronological order (see also Table 1). Along with these data we provide information on possible decadal-scale forcings (volcanic and solar) for global coolings that might have induced glacier advances. Please note that we report here, as well as in the regional chapters, the recalculated ${ }^{10} \mathrm{Be}$ ages from original publications by Schaefer et al. (2009), Jomelli et al. (2014), and Stroup et al. (2014) (See details in the table 1 SM).

CE 1-200s

The evidence of glacier advances in the first two centuries CE is rare. This time is known in Europe as the warm Roman period (Wanner et al., 2008). Glaciers were smaller or close to the late $20^{\text {th }}$ century extent not only in Europe (the Alps and Southern Scandinavia), but also in Altay, Tibet, Western Canada and Canadian Arctic (see details in section 4). The forelands of some glaciers were covered by forest (e.g., Llewellyn Glacier in British Columbia; Clague et al., 2010). In contrast an advance between 250 
BCE and CE 150 probably occurred in Iceland (Kirkbride and Winkler, 2012). Schaefer et al. (2009) dated three of the most prominent advances in the past two millennia in New Zealand between CE 5 and CE 180 (Schaefer et al., 2009).

200s-300s CE

Advances during this period are recorded in many regions in both hemispheres. In the Arctic, an extensive glacial expansion throughout Baffin Island occurred between CE 250 and CE 400 (Miller et al., 2012; 2013) and at CE $350 \pm 200$ in western Svalbard (Reusche et al., 2014). In Alaska an advance occurred between CE 200 and CE 320 (Rothlisberger, 1986). Llewellyn Glacier in British Columbia advanced into mature forest between CE 300 and CE 500 (Clague et al., 2010). Detailed records in the European Alps (Nicolussi and Patzelt, 2001; Holzhauser et al., 2005; Le Roy et al., 2015) prove first advances after the warm Roman period from the late $3^{\text {rd }}$ to early $5^{\text {th }}$ century (e.g., a synchronous advance recorded between CE 312 and CE 337 at Mer de Glace and around CE $335 \mathrm{CE}$ at Gepatschferner). Two separate advances at $\sim$ CE 270 and $\sim$ CE 410 were identified at Great Aletsch Glacier closely). Some of these advances may match a climatically effective eruption at CE 266 (Sigl et al., 2015), although the dating uncertainties of moraines are generally still too large for more definitive conclusions.

\section{0s-700s CE}

The advances around CE 600 are identified as a major regional event in the northwestern of North America (Reyes et al., 2006). Advances occurred at CE 550-720 in British Columbia and Alaska (Barclay et al., 2009a,b, 2013; Zander et al., 2013). They are 
recorded in southwest Greenland at CE $490 \pm 110$ (Winsor et al., 2014), in Iceland (three advances between CE 450 and 550) (Kirkbride and Dugmore, 2008), in Scandinavia in CE 600-700 (Matthews and Dresser, 2008), in southeastern Tibetan Plateau in CE 400600 (Yang et al., 2008), in New Zealand in CE 430 (Schaefer et al., 2009), in the tropics in Africa at Mt. Kenya (between CE 400 and 750) (Karlen et al., 1999) and in South

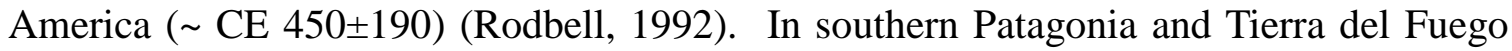
advances are recorded between the 4th and 9th centuries (Strelin et al., 2008; Masiokas et al., 2009a). In some regions glaciers were close to their past millennium maxima, e.g. Great Aletsch Glacier and Mer de Glace in the Alps (Holzhauser et al., 2005; Le Roy et al., 2015). Unfortunately the dating is still too poor to assess the inter-regional synchronicity or distinguish individual stages. Recently Büntgen et al. (2016) identified a long-lasting cooling between CE 536 and $\sim$ CE 660 in Eurasia after a set of large volcanic eruptions in CE 536, 540 and 547 and named this period the "Late Antique Little Ice Age". Grand Solar Minimum (GSM) which occurred at the end of the 7 th century (Steinhilber et al., 2009) also contributed to this cooling and probably to the glacier advances around this time.

800s-900s CE

In the European Alps the advance around CE 835 was almost equal to the past millennium maximum extent at some glaciers (e.g. Suldenferner) (Nicolussi et al., 2006). The advance between CE 800 and 1150 was the largest in the past 2 ka in Gongga Shan (Yang et al., 2008). An advance is recorded on Baffin Island between about CE 850 and 950 (Miller et al., 2012) and in British Columbia between CE 865 and 940 (Clague et al., 
2010). Advances probably occurred also in Spitsbergen (CE 700-820) (Guilizzoni et al., 2006) and in Franz Josef Land (CE 720-880) (Lubinski et al, 1999). No clear evidence of correspondence with volcanic eruptions is available for this period. Volcanic events of moderate magnitude occurred in CE 764 and CE 853 (Sigl et al., 2014).

900-1000 CE

Glaciers were retreating in the European Alps during the late $9^{\text {th }}$ to $11^{\text {th }}$ centuries (Grove, 2004; Holzhauser et al., 2005; Simmoneau et al., 2014; Hafner et al., 2012), around CE 950 in southern coastal Alaska (Wiles et al., 2014), and between CE 900 and 1100 in British Columbia (Clague et al., 2010). Glacier advances in the 10th century were quite rare, perhaps because this was a time when climate was quite unperturbed by anomalous solar or volcanic forcing (Bradley et al., 2016). An advance around CE 1000 occurred in the central Himalayas and, the southeastern Tibetan Plateau (Yang et al., 2008), in Colombia (Jomelli et al., 2014), and New Zealand (Schaefer et al., 2009). In western Canada, some glaciers advanced between CE 1030 and 1210 (Clague et al., 2010), and in Baffin Bay an advance is dated to between $\sim \mathrm{CE} 1050$ and 1220 (Young et al., 2015). One strong high latitude volcanic event is reported for CE 939 (Sigl et al., 2015), but we do not find any clear evidence of potential glacier advance around this time.

\section{CE 1100s}

Although the $12^{\text {th }}$ century is sometimes considered the peak of the warm period (MCA) (Lamb, 1965), advances in the CE 1120s to 1180s are reported in many regions (Grove, 2004) (see Table 1), e.g., western Canada (Luckman, 1986, 1996; Koch and Clague, 
2010), the European Alps (Le Roy et al., 2015), monsoon Asia (Röthlisberger and Geyh, 1985), Greenland (Young et al., 2015), Franz Josef Land (Lubinski et al., 1999), and New Zealand (Schaefer et al., 2009). Two volcanic eruptions in CE 1108 and 1170 (Sigl et al., 2015) may be responsible for these advances, but at the moment this is only our speculation based on coincidence of the dates.

CE 1200s

Miller et al. (2012) dated advances of glaciers on Baffin Island to CE 1260-1280. Glaciers in eastern (Young et al., 2015) and south-eastern Greenland (Balascio et al., 2015) advanced around the same time in CE 1250-1300. In the European Alps, Mer de Glace advanced between $\sim \mathrm{CE} 1248$ and 1278-1296 (Le Roy et al., 2015), and Gepatschferner advanced around CE 1286 (Nicolussi and Patzelt, 2001). Nazarov et al. (2012) found evidence of trees killed by advancing glaciers in the Altay in the CE 1200s1250s, and Soler Glacier of the Northern Patagonian Icefield advanced between CE 1222 and 1342 (Glasser et al., 2002). Advances in the $13^{\text {th }}$ century are also described in Alaska, Western Canada, Scandinavia, Iceland, and the Russian Arctic (regional descriptions in Section 4). The advances might be related to the volcanic eruptions that occurred in CE 1230, 1258, and 1286 (Sigl et al., 2015). The CE 1258 volcanic event was the strongest of the past two millennia, and the period between CE 1251 and 1310 is identified as one of the "volcanic-solar downturns" (PAGES 2ka Consortium, 2013) characterized by strong cooling.

1300s CE 
A period of glacial activity, likely of global significance, experienced its first culmination in the mid/late $14^{\text {th }}$ century: e.g., Mer de Glace in the Alps after CE 1352 (Le Roy et al., 2015); Franklin Glacier in western Canada in CE 1340-1390 (Mood and Smith, 2015); Spitsbergen after CE 1350 (Guilizzoni et al., 2006); southern Patagonia after CE 1350 (Masiokas et al., 2009 a); and New Zealand around CE 1355 (Schaefer et al., 2009). Glaciers in the Peruvian Andes also began to advance around the mid 14th century after a long period of retreat (Stansell et al., 2013). The glacial activity seems to have persisted at least until the end of this century. A strong low latitude eruption with bipolar climatic effects that occurred in CE 1345 (Sigl et al., 2013) was possibly responsible for the glacier advances recorded in the mid $14^{\text {th }}$ century.

1400s-1500s

An advance around CE 1460s on Baffin Island (Miller et al., 2012) is synchronous with the beginning of advances in southeast Greenland (CE 1450-1630) (Balascio et al., 2015), in the Altay (CE 1440s-1510s) (Nazarov et al., 2012), and in Central Asia (CE 14501850) (Röthlisberger and Geyh, 1985). In the tropical Andes Stroup et al. (2014, 2015) report an advance of Qori Kalis in CE $1500 \pm 20$, and in New Zealand the advance around CE 1435 was one of the most prominent (Schaefer et al., 2009; Putnam et al., 2012). A strong Pacific Ocean eruption (Kuwae/Vanuatu) that consisted probably of two events in CE 1452 and 1458 (Sigl et al., 2013, 2015) and the Spörer solar minimum ( CE 1450) roughly coincide with the beginning of above mentioned glacier advances. Glacial advances in $16^{\text {th }}$ century were generally less common (see Table 1). 
Glaciers advanced between CE 1640 and 1740 in the Altay (Nazarov et al., 2012), in CE 1640s-1670s in south-central Alaska (Barclay et al., 2009a; Daigle and Kaufman, 2009), and around CE 1600 in Greenland (Briner et al., 2010, 2011). Two events are recorded in New Zealand around CE 1605 (Schaefer et al., 2009). In the southern Patagonian Andes, advances occurred between the late $16^{\text {th }}$ century and the mid $17^{\text {th }}$ century (Glasser et al., 2004; 2011; Koch and Kilian, 2005; Aravena, 2007; Masiokas et al., 2009a). An advance between CE 1640 and CE 1730 occurred in the tropical Andes (Polissar et al., 2006), in CE 1638-1639 in northern Patagonia (at Frias Glacier) (Masiokas et al., 2009a), and in the middle of the $17^{\text {th }}$ century on Franz Josef Land (Lubinski et al., 1999). The most detailed and best-dated glacier advances are reported in the Alps in the CE 1600s, 1640s, and 1680s (Zumbühl et al., 1983; Grove, 2004; Nicolussi et al., 2006, Nussbaumer et al., 2007; Ivy-Ochs et al., 2009; Le Roy et al., 2015). They closely correlate with eruptions that occurred in CE 1601, 1641 and 1695 (Sigl et al., 2015). Volcanic-solar downturns in CE 1581-1610 and 1641-1700 were identified in the PAGES 2 ka temperature reconstruction (PAGES 2 ka Consortium, 2013). In many regions the advances of the $17^{\text {th }}$ century were of a major magnitude (see details in section 5.2).

$1700 s$

Two advances are recorded in the European Alps around CE 1720 and 1775 (Zumbühl et al., 1983; Nicolussi and Patzelt, 2001; Nussbaumer et al., 2007), around CE 1725 in Spitsbergen (Røthe et al., 2015), around CE 1720 in Iceland (Larsen et al., 2015), shortly before 1737 in Kamchatka (Solomina et al., 1995), around 1735 and around 1770 in New Zealand (Schaefer et al., 2009; Putnam et al., 2012), and around $\sim$ CE 1700, 1730 
and 1780 in the tropical Andes (Rabatel et al 2005, 2008: Jomelli et al 2014; Stroup et al., 2014). Tree-ring dated moraines in southern Patagonia were deposited at $\sim \mathrm{CE} 1740$ s (Masiokas et al., 2009a,b). Advances between CE 1746 and 1785 occurred in the area of monsoonal temperate glaciers in Asia (Brauning, 2006). In southern Norway glaciers advanced in CE 1740-1750 and CE 1780-1790 (Matthews and Dresser, 2008; Nesje, 2009). One group of these advances (around CE 1770-1780) clusters around the date CE 1783 of the Laky eruption in Iceland, however in the Alps, where the dating is more precise the culmination of the late 18th century advance occurred earlier than this eruption.

1800s-1900s

Numerous glacier advances in the $19^{\text {th }}$ century occurred and were directly observed in many mountain regions. They are usually recognized by the presence of well-preserved moraines of one of the last millennium maxima and of subsequent re-advances of retreating glaciers. In many regions, such as the European Alps, Scandinavia, Altay, Patagonia glacial records of the 19th century are accurately dated, described and analyzed (e.g. Grove, 2004; Wanner, 2000; Nicolussi and Patzelt, 2001; Holzhauser et al., 2005; Luckman, 2000; Zumbühl et al., 2008; Masiokas et al., 2009a, WGMS, 2008 etc.). Two periods of major advances in the European Alps at around CE 1820 and 1855-1860 were followed by minor re-advances in the 1890s. In most regions the retreat from the $19^{\text {th }}$ century maximum began in the 1860 s, although in some Arctic regions the glaciers were still close to their maxima at the beginning of $20^{\text {th }}$ century. During the first three decades of the $19^{\text {th }}$ century - a period of several strong advances - a covariance between a Grand 
Solar Minimum (Dalton) and several large tropical volcanic eruptions is observed. The climatic effects of the Tambora eruption in CE 1815 and another major low latitude eruption in CE 1809 have been well studied (e.g. Harington 1992; Grove, 2004).

2000 s to the present

In $20^{\text {th }}$ and early $21^{\text {st }}$ centuries the global trend of glacier retreat with some episodes of regionally variable minor re-advances or still-stands is well documented, for example in the 1920s, 1970s and 1990s (Lemke et al., 2007; WGMS, 2008; Vaughan et al., 2013).

We summed the number of glacier advances for 50-year long intervals spanning the time period from CE 1 to CE 2000 for all regions considered here and analyzed the agreement of the resulting time series. If the time (the date) of advance covered more than 50 years it was included in subsequent 50-years long intervals. Although this approach has serious limitations it still provides a general idea of the coherence of the time of advances across the globe. The number of glacial advances for all regions is significantly inter-correlated. This coherence is clear for both individual regions (Fig. 5) and for cumulative curves of glacier advances for high, mid and low latitudes (Fig. 6). The correlation is partly generated by the shared millennial-scale trends towards both enhancing glacial activity and increasing sample depth (Table $3 \mathrm{SM}$ ). Removing the long-term trend results in fewer significant correlations between regions (Table $3 \mathrm{SM}$ ), though many regions still do demonstrate century-scale co-variability. Based on this review we identified potential synchronicity of glacier advances during the Common Era that cluster in the CE 200s300s, 400s-600s, 800s, around CE 1000 as well as around CE 1150s, 1280s, 1350s, 1400s, 1450s, 1600s, 1640s, 1680s, 1720s, 1770s, 1820s, 1850s-1860s, 1890s, 1900s- 
1920s, 1970s-1980s and 1990s. Synchronicity of some glacier advances over the past one to two millennia was advocated before by Röthlisberger (1986), Grove (2004), Matthews (2007), Stroup et al. (2014) and Solomina et al. (2015). However, the gaps inherent in terrestrial glacial records, the scarcity of data for certain times, together with the limited accuracy associated with many of the proxy records and the complexity of glacier sensitivity to climate parameters (Paterson, 1994; Oerlemans, 2001)) all set limits on identifying the global synchronicity of glacier variations.

\subsection{Possible external forcings of glacier variations in the past $2 \mathrm{ka}$}

Circulation dynamics and their related energy and mass fluxes react in a complex manner to different forcing factors as well as to internal (chaotic) variability and account for past global glacier advances and retreats on different time scales. It is challenging to translate forcings and internal (chaotic) variability into circulation dynamics, and precise regional or local temperature and precipitation values with seasonal or higher resolution for the past two millennia are also difficult to generate, thus we can only speculate about their significance for past glacier advances and retreats. On the longer (millennial) timescale changes in orbital forcing, mainly during the summer season, played a major role, causing the latitudinal displacement of the global circulation belts (Wanner et al., 2008). On centennial to decadal timescales additional factors contributed to glacier fluctuations: such as large tropical volcanic eruptions, solar irradiance variability and greenhouse gas concentrations as well as large-scale internal variability (mainly El Niño Southern Oscillation (ENSO), Pacific Decadal Variability (PDV), North Atlantic Oscillation (NAO) and Atlantic Multidecadal Oscillation (AMO) (PAGES 2ka, 2013). However, the 
fairly coherent response seen in the overall record of glacier advances (Figure 6) suggests that regional circulation patterns were not the primary factors influencing glacier dynamics.

Generally, the opposite orbital trends in the Northern and Southern hemispheres in the past two millennia would result in a gradual increase of glacier sizes in the Northern Hemisphere and in the decrease of those in the Southern Hemisphere. The orbital signal is indeed well manifested in the Holocene glacier variations (e.g. Solomina et al., 2015) however in the past two millennia it is masked by the higher frequency perturbations such as solar minima and sets of consequent volcanic eruptions reversing the pattern of glacier variations expected from orbital forcing. This is the case in some regions of the Southern Hemisphere where glacial activity had increased by the second half of the second millennium despite the increase of solar insolation in summer induced by the orbital signal. Several hypotheses have been suggested to explain this phenomenon (Broecker, 2000; Denton and Broecker, 2008; Schaefer et al., 2009), but this problem is not yet completely resolved. Several authors have drawn attention to the coincidence of wellconstrained glacial chronologies of past centuries with solar activity (Luckman, 2000; Wiles et al., 2004, 2008; Holzhauser et al. 2005; Hormes et al., 2006; Nussbaumer et al., 2011a,b; MacGregor et al., 2011). Hormes et al. (2006) demonstrated the high correlation of glacier length changes with total solar irradiance (up to $\mathrm{r}^{2}=0.79$ with 9-14 year lags). However, neither the magnitude of total solar irradiance (TSI) changes, nor the effects of such changes on the climate system, are well understood (Lockwood, 2012) and so a simple temporal correlation with available TSI proxies must be treated with caution. 
Porter $(1981,1986)$ suggested that volcanic eruptions are the primary forcing of glacier fluctuations on a decadal timescale, however it was difficult to explain how the shortterm coolings induced by the volcanic eruptions can result in glacier advances that last sometimes last for decades. Recently, Sigl et al. (2015) showed that the cooling may persist at least ten years after the largest eruptions. Notably, some of these large eruptions occurred at the same time as solar minima ("volcanic-solar overturns"; PAGES 2 ka, 2013). The combination of solar minima and volcanic forcing may have been a decisive factor in driving widespread potentially globally synchronous glacier advances of the past. Miller et al. (2012) suggested an additional mechanism to maintain the short-lived cooling periods that follow explosive eruptions: positive feedbacks related to the expansion of Arctic sea-ice. They noted that abrupt summer cooling and expansion of Canadian Arctic ice caps between CE 1275 and 1300, followed by even stronger cooling and further advances at CE 1430-1455, coincided with major volcanic eruptions, at times of decreased irradiance during Grand Solar Minima (Steinhilber et al., 2009).

Unfortunately, as we showed in this overview, the precision of the majority of the dates of glacier advances is still not high enough to firmly connect the decadal scale external forcing and glacier advances, especially in the first millennium, though there is a certain coincidence between glacier advances and large volcanic eruptions that occurred in $\mathrm{CE}$ $1258,1345,1458,1601,1641,1695,1783$ and 1815 (Sigl et al., 2015; see details in 5.3 and in Table 1).

Along with the global-scale forcing factors, modes of internal climate system variability, such as the NAO (Nesje, 2009; Reichert et al., 2001; Six et al., 2001; Imhof et al., 2012; 
Marzeion and Nesje, 2012; Larsen et al., 2013; Young et al., 2015), ENSO (Koch and Clague, 2011), AMO (Luethi, 2014), and the IPO (Interdecadal Pacific Index: Schaefer et al., 2009) modulate regional climates, and may thereby affect glacier variations in some areas. Such circulation modes may result in asynchronous or sometimes antiphased cycles of glacier advances and retreats (e.g. Scandinavia and the Alps in the early 18th century (Nesje, Dahl, 2003), Iceland and the Alps between CE 1550 and CE 1680 (Larsen et al., 2013). Koch and Clague (2011) reported that several glaciers in western North America advanced up to their LIA limits in Medieval time, possibly due to increased winter precipitation forced by La Niña-like conditions.

Denton and Broecker (2008) suggested that the Atlantic Multidecadal Oscillation (AMO) could have had thermal effects across the Northern Hemisphere, and thus provide an explanation for the synchronicity of glacier variations in the European Alps and in western North America. Due to the bipolar seesaw effect, fluctuations of glaciers in the Southern Hemisphere would be expected to show the opposite behaviour at the decadal and multi-decadal scale. However, as shown in section 5.3 of this paper several advances reported for the Southern Hemisphere in Patagonia and New Zealand (e.g. CE 1150, $1350,1430,1600,1735,1770)$ are indistinguishable from those of the Northern Hemisphere within the given accuracy of the dates (see Table 1). Furthermore, Schaefer et al. (2009) claim that their ${ }^{10} \mathrm{Be}$ dates on Holocene moraines support neither synchronicity nor rhythmic asynchrony in glacier fluctuations in the Northern and Southern Hemispheres. They suggest that IPO may have played a crucial role in climate and glacier fluctuations in New Zealand. 
Anthropogenic warming is a global signal that is currently resulting in retreat of glaciers in both hemispheres (Lembke et al., 2007; Vaughan et al., 2013). We did not find evidence of any other globally uniform period of glacier retreat in the past two millennia except for the modern one, although in the $1^{\text {st }}-2^{\text {nd }}$ and $10^{\text {th }}$ centuries the number of advances seems to have been quite low. However, our knowledge of the number and extent of glaciers in retreat in the past is also limited, especially in the tropics and in the Southern Hemisphere. In general the fast and global retreat of mountain glaciers in the $20^{\text {th }}$ to $21^{\text {st }}$ centuries appears highly unusual in the context of the two preceding millennia as well as for the entire Holocene (Solomina et al., 2015) and is strongly influenced by the rising temperature induced by anthropogenic forcing (Oerlemans, 1994)

\section{Conclusions}

\section{A. Synchroneity}

1. Considering the global database reviewed in this paper, a number of advances in the past millennium cluster in CE 200s-300s, 400s-600s, 800s, CE 1000 as well as around CE 1150s, 1280s, 1350s, 1400s, 1450s, 1600s, 1640s, 1680s, 1720s, 1770s, 1820s, 1850s1860s, 1890s, 1900s-1920s, 1970s-1980s and 1990s. However, in some regions the data are too scarce and the precision of the dating is too low for a definite conclusion about the global synchrony of glacier advances. Advances occurred at one or more locations in every century of the first millennium CE, but it is difficult to determine if these were of more than regional significance. Very few cases of advancing glaciers are reported for the $1^{\text {st }}$ to $2^{\text {nd }}$ and the $10^{\text {th }}$ centuries CE. 
2. There is a coherency in the number of glacier advances in the past 2 millennia in both hemispheres, including the glaciers at low latitudes; the most extensive and geographically widespread were in the $13^{\text {th }}$ to $19^{\text {th }}$ centuries and indicate that the LIA was of global significance (Grove, 2001, 2004).

\section{B. Magnitude of changes}

1. The full range of glacier variations in the past two millennia is unknown. During the maximum advances $\triangle$ ELA ranged from 10 to $20 \mathrm{~m}$ in arid Central Asia, between 100 to $150 \mathrm{~m}$ in the mid latitudes and up to $500 \mathrm{~m}$ in the tropics. During the $1 \mathrm{st}$ and $2^{\text {nd }}$ centuries, ELAs were generally higher than during the $21^{\text {st }}$ century by $20-25 \mathrm{~m}$ in Scandinavia, up to $100 \mathrm{~m}$ in Spitsbergen, and at least $200 \mathrm{~m}$ in the eastern Canadian Arctic.

2. The number of recorded glacial advances in the $1^{\text {st }}$ millennium $\mathrm{CE}$ is much smaller than in the $2^{\text {nd }}$ millennium, probably not only due to less numerous advances, but more importantly because they were of generally smaller magnitude, hence the evidence was subsequently overridden. Some advances (e.g. in $6^{\text {th }}$ to $7^{\text {th }}$ centuries in Arctic Canada, West Greenland, Svalbard, the Alps) were of similar magnitude to those of the "classical" LIA and, thus required similarly strong external forcing.

\section{External Forcings}

1. In most cases considered here summer temperature rather than winter precipitation was the primary driver of decadal to century scale glacier variations over the past two millennia. In some areas, such as the maritime regions in the northern North Atlantic, 
western Canada, Patagonia, and New Zealand, glacier advances during the past two millennia were also dependent on the winter precipitation regime, driven by prevailing circulation modes.

2. Higher levels of explosive volcanic activity, perhaps aided by low solar irradiance forcing and amplified by internal climate system feedbacks (e.g. sea-ice expansion), led to the expansion of glaciers between the beginning of the 13 th to the early $19^{\text {th }}$ centuries. Southern Hemisphere glacier advances occurred in the same period despite summer insolation increases, and neither sea ice nor AMOC provides a major direct trigger for glacier growth in the Southern Hemisphere in the past two millennia. Thus the linkages across the hemispheres and identifications of forcings remain largely unresolved.

3. Multiple forcings are responsible for glacier advances. Several advances, such as those occurring in the $6^{\text {th }}$ to $7^{\text {th }}$ centuries CE, in the late $13^{\text {th }}$, in the $14^{\text {th }}$, in the early and mid $15^{\text {th }}$, as well as in the $17^{\text {th }}$ to early $19^{\text {th }}$ centuries generally coincide with the timing of large explosive low latitude volcanic eruptions and minima of solar activity.

\section{D. $20^{\text {th }}$ century}

1. Glaciers were as small as today (late $20^{\text {th }}$ - early $21^{\text {st }}$ centuries) in some regions and likely even smaller several times in the past two millennia. However, the current globally widespread glacier retreat is unusual in the context of the past two millennia and, indeed, for the whole Holocene. Contemporary glacier retreat breaks a long-term trend of increased glacier activity that dominated the past several millennia. The trend of glacier retreat is global, and the rate of this retreat has increased in the past few decades. The 
observed widespread glacial retreat in the past $100-150$ years requires additional forcing outside the realm of natural changes for their explanation. With a high probability anthropogenic greenhouse gas emissions are the most likely reason for the prevalent, ongoing global ice loss.

\section{Acknowledgements}

We are grateful to our collegues Zhu Haifeng, Philipp Hochreuther, David Loibl, Andrey Nazarov, Vladimir Myglan, Irina Bushueva, Liudmila Lazukova, Vladimir Mikhalenko, Mikhail Alexandrin, Elya Zozovskaya, Léo Martin for their valuable help and additional material that we requested for this paper. M. Masiokas acknowledges support from Consejo Nacional de Investigaciones Científicas y Técnicas (CONICET) and Agencia Nacional de Promoción Científica y Técnica (grants PICT 2007-0379 and PICT 20101438. Financial support for V.Jomelli was provided by the LMI GREAT ICE, the ANR El Paso programme no. 10-blan-68-01 and CEPS Green Greenland project (grant ANR10-CEPL-0008). LDEO contribution no. XXXX. G. Wiles was supported by the U.S. National Science Foundation under grants ATM-0902799, ATM-0902799, and AGS1502186. O.Solomina was supported by the scientific programms of Russian Academy of Sciences.

We very much appreciated the comments of Stepan Harrison and anonymous reviewer of the first versions of this paper and the understanding of the QSR team that was very supportive. 


\section{References}

Aa, A.R., 1996. Topographic control of equilibrium-line altitude depression on reconstructed 'Little Ice Age' glaciers, Grovabreen, Western Norway. The Holocene 6, 82-89.Agatova, A.R., Nazarov, A.N., Nepop, R.K., Rodnight, H., 2012. Holocene glacier fluctuations and climate changes in the southeastern part of the Russian Altai (South Siberia) based on a radiocarbon chronology. Quaternary Science Reviews 43(8), 74-93.

Abbott, M. B., Wolfe, B. B., Aravena, R., Wolfe, A. P., \& Seltzer, G. O. 2000. Holocene hydrological reconstructions from stable isotopes and paleolimnology, Cordillera Real, Bolivia. Quaternary Science Reviews, 19(17), 1801-1820.

Allen, S., Smith, D.J., 2007. Late Holocene glacial activity of Bridge Glacier, British Columbia Coast Mountains. Canadian Journal of Earth Science 44, 1753-1773.

Anchukaitis, K.J., D’Arrigo, R., Andreu-Hayles, L., Frank, D., Verstege, A., Curtis, A., Buckley, B.M., Jacoby, G.C., Cook, E.R., 2013. Tree-ring reconstructed summer temperatures from north-west North America during the past nine centuries. Journal of Climate 26, 3001-3012.

Anderson, R.K., Miller, G.H., Briner, J.P., Lifton, N.A., DeVogel, S.B., 2008. A millennial perspective on Arctic warming from $14 \mathrm{C}$ in quartz and plants emerging beneath ice caps. Geophysical Research Letters 35, L01502, doi:01510.01029/02007GL032057.

Aniya, M., 1995. Holocene glacial chronology in Patagonia: Tyndall and Upsala glaciers. Arctic and Alpine Research 27, 311-322. 
Aniya, M., 2013. Holocene glaciations of Hielo Patagónico (Patagonia Icefield), South America: A brief review. Geochemical Journal 47, 97-105.

Aniya, M., Skvarca, P., 2012. Little Ice Age advances of Glaciar Perito Moreno, Hielo Patagónico Sur, South America. Bull. Glaciol. Res. 30, 1-8.

Aravena, J.C., 2007. Reconstructing climate variability in southern Chilean Andes. Ph.D. Dissertation, University of Western Ontario, London, Ontario, Canada, 220 PP.

Badding, M.E., Briner, J.P., Kaufman, D.S., 2013. 10Be ages of late Pleistocene deglaciation and Neoglaciation in the north-central Brooks Range, Arctic Alaska. Journal of Quaternary Sciences 28, 95-102.

Baeten, N.J., Forwick, M., Vogt, Ch., Vorren, T.O., 2010. Svalbard environments and glacial activity in Billefjorden, Late Weichselian and Holocene sedimentary Geological Society, London, Special Publications 344, 207-223. doi: 10.1144/SP344.15 .

Bakke, J., Dahl, S.O., Paasche, Ø., Løvlie, R., Nesje, A., 2005a. Glacier fluctuations, equilibrium-line altitudes and palaeoclimate in Lyngen, northern Norway during the Lateglacial and Holocene. The Holocene 15, 387-409.

Bakke, J., Dahl, S.O., Nesje, A., 2005b. Lateglacial and early Holocene palaeoclimatic reconstruction based on glacier fluctuations and equilibrium-line altitudes at northern Folgefonna, Hardanger, western Norway. Journal of Quaternary Science, 20(2), 179-198.

Bakke, J., Lie, Ø., Nesje, A., Dahl, S.O., Paasche, Ø., 2005c. Utilizing physical sediment variability in glacier-fed lakes for continuous glacier reconstructions during the Holocene, northern Folgefonna, western Norway. The Holocene 15, 161-176. 
Bakke, J., Lie, Ø., Dahl, S.O., Nesje, A., Bjune, A., 2008. Strength and spatial patterns of the Holocene wintertime westerlies in the NE Atlantic region. Global and Planetary Change 60, 28-41.

Bakke, J., Dahl, S.O., Paasche, Ø., Simonsen, J., Kvisvik, B., Bakke, K., Nesje, A., 2010. A complete record of Holocene glacier variability at Austre Okstindbreen, northern Norway: an integrated approach. Quaternary Science Reviews 29, 1246-1262.

Balascio, N. L., D'Andrea, W. J., \& Bradley, R. S., 2015. Glacier response to North Atlantic climate variability during the Holocene. Climate of the Past, 11(12), 1587-1598.

Balco, G., 2011. Contributions and unrealized potential contributions of cosmogenicnuclide exposure dating to glacier chronology, 1990-2010. Quaternary Science Reviews 30, 3-27.

Balco, G., Briner, J.P., Finkel, R.C., Rayburn, J.A., Ridge, J.C., Schaefer, J.M., 2009. Regional beryllium-10 production rate calibration for late-glacial northeastern North America. Quaternary Geochronology 4, 93-107.

Baranowski, S., Karlén, W., 1976. Remnants of Viking Age tundra in Spitsbergen and northern Scandinavia. Geografiska Annaler 58, 35-39.

Barclay, D.J., Wiles, G.C., Calkin, P.E., 1999. A 1119-year tree-ring-width chronology from western Prince William Sound, southern Alaska. The Holocene 9, 79-84.

Barclay, D.J., Wiles, G.C., Calkin, P.E., 2009a. Holocene glacier fluctuations in Alaska. Quaternary Science Reviews 28, 2034-2048. 
Barclay, D.J., Wiles, G.C., Calkin, P.E., 2009b. Tree-ring crossdates for a First Millennium AD advance of Tebenkof Glacier, southern Alaska. Quaternary Science Reviews 71, 22-26.

Barclay, D.J., Yager, E.M., Graves, J., Kloczko, M., Calkin, P.E., 2013. Late Holocene glacial history of the Copper River Delta, coastal south-central Alaska, and controls on valley glacier fluctuations. Quaternary Science Reviews 81, 74-89, doi: 10.1016/j.quascirev.2013.10.001.

Barr, I.D., and Solomina, O., 2014. Holocene glacier fluctuations upon the Kamchatka Peninsula. Global and Planetary Change 13, 110-120, DOI: 10.1016/j.gloplacha.2013.08.005.

Baume, O., Marcinek, J., 1998. Gletscher und Landschaften des Elbrusgebietes: Beiträge zur glazialen, periglazialen und kryogenen Morphogenese im zentralen Kaukasus / J. Marcinek. Justus Perthes Verlag.

Benn, D.I., Owen, L.A., Osmaston, H.A., Seltzer, G.O., Porter, S.C., Mark, B., 2005. Reconstruction of equilibrium-line altitudes for tropical and sub-tropical glaciers. Quaternary International 138/139, 8-21.

Bennike, O., 2002. Late Quaternary history of Washington Land, North Greeland. Boreas 31, 260-272.

Bennike, O., \& Sparrenbom, C. J. 2007. Dating of the Narssarssuaq stade in southern Greenland. The Holocene, 17(2), 279-282.

Bennike, O., \& Weidick, A. 2001. Late Quaternary history around Nioghalvfjerdsfjorden and Jøkelbugten, North - East Greenland. Boreas, 30(3), 205-227. 
Beschel, R.E., 1950. Flechten als Altersmaßstab rezenter Moränen. Zeitschrift für Gletscherkunde und Geologie 1, 152-162. (Translated by Barr, W.), 1973. Lichens as a measure of the age of recent moraines. Arctic and Alpine Research 5, 303-309.).

Bertrand, S., Hughen, K. A., Lamy, F., Stuut, J. B. W., Torrejon, F., \& Lange, C. B. 2012. Precipitation as the main driver of Neoglacial fluctuations of Gualas glacier, Northern Patagonian Icefield.

Bickerton, R.W., Matthews, J.A., 1993. 'Little Ice Age' variations of outlet glaciers from the Jostedalsbreen ice cap, southern Norway: a regional lichenometric-dating study of ice-marginal moraine sequences and their climatic significance. Journal of Quaternary Science 8, 45-66.

Bijkerk, A., 1984. Lichenometric dating of Neoglacial deposits in the McKinley Park area, Alaska. In: Ten Brink, N.W. (Ed.), North Alaska Range Project Final Report on 1978-1982 Geo-archeological Studies. National Geographical Society and National Park Service, p. 54. Part 6.

Bjørk, A.A., Kjær, K.H., Korsgaard, N.J., Khan, S.A., Kjeldsen, K.K., Andresen, C.S., Box, J.E., Larsen, N.K., Funder S., 2012. An aerial view of 80 years of climate-related glacier fluctuations in southeast Greenland. Nature Geoscience 5, 427-432, doi:10.1038/ngeo1481.

Björnsson, H., Pálsson, F., Guðmundsson, S., Magnússon, E., Aðalgeirsdóttir, G., Jóhannesson, T., Berthier, E., Sigurðsson, O., Thorsteinsson, Th., 2013. Contribution of Icelandic ice caps to sea level rise: trends and variability since the Little Ice Age. Geophysical Research Letters 40, 1546-1550, doi: 10.1002/grl.50278. 
Black, J., Miller, G.H., Geirsdóttir, Á., Manley, W., Björnsson H., 2004. Sediment thickness and Holocene erosion rates derived from a seismic survey of Hvitárvatn, central Iceland. JÖKULL 2004 54, 37-56.

Blard, P.-H., Braucher, R., Lavé, J., Bourlès, D., 2013a. Cosmogenic 10Be production rate calibrated against $3 \mathrm{He}$ in the high Tropical Andes (3800-4900 m, 20-22 $\left.{ }^{\circ} \mathrm{S}\right)$. Earth Planet. Sci. Lett. 382, 140-149.

Blard, P-H, Pik, R., Lavé J., Bourles D., Burnard P.G., Yokochi R., Marty B., Trusdell, F., 2013b. Cosmogenic $3 \mathrm{He}$ production rate in the high tropical Andes $\left(3800 \mathrm{~m}, 20^{\circ} \mathrm{S}\right)$ : implications for the local last glacial maximum. Earth Planet. Sci. Lett. 377-378, 260275.

Boldt, B.R., Kaufman, D.S., McKay, N.P., Briner, J.P., 2015. Holocene summer temperature reconstructions from sedimentary chlorophyll content, with treatment of age uncertainties, Kurupa Lake, Arctic Alaska. The Holocene, DOI $10.1177 / 0959683614565929$.

Bowerman, N.D., Clark, D.H., 2011. Holocene glaciation of the central Sierra Nevada, California. Quaternary Science Reviews 30, 1067-1085.

Bradley, R. S., Wanner, H., \& Diaz, H. F. 2016. The Medieval Quiet Period. The Holocene, 0959683615622552.

Bräuning, A., 2006. Tree-ring evidence of 'Little Ice Age' glacier advances in southern Tibet. The Holocene 16, 369-380. 
Briffa, K.R., Melvin, T.M., Osborn, T.J., Hantemirov, R.M., Kirdyanov, A.V., Mazepa, V.S., Shiyatov, S.G., Esper, J., 2013. Reassessing the evidence for tree-growth and inferred temperature change during the Common Era in Yamalia, northwest Siberia. Quaternary Science Reviews 72, 83-107, doi: 10.1016/j.quascirev.2013.04.008.

Briner, J.P., Stewart, H.A.M., Young, N.E., Philipps, W., Losee, S., 2010. Using proglacial-threshold lakes to constrain fluctuations of the Jakobshavn Isbrae ice margin, western Greenland, during the Holocene. Quaternary Science Reviews 29, 3861-3874.

Briner, J.P., Young, N.E., Thomas, E.K., Stewart, H.A.M., Losee, S., Truex, S., 2011. Varve and radiocarbon dating support the rapid advance of Jakobshavn Isbrae during the Little Ice Age. Quaternary Science Reviews 30, 2476-2486.

Briner, J.P., Håkansson, L., Bennike, O., 2013. The deglaciation and neoglaciation of Upernavik Isstrøm, Greenland. Quat. Res. 80, 459-467. http://dx.doi.org/ 10.1016/j.yqres.2013.09.008.

Broecker, W.S., 2000. Was a change in thermohaline circulation responsible for the Little Ice Age? Proceedings of the National Academy of Sciences 97(4), 1339-1342.

Büntgen, U., Tegel, W., Nicolussi, K., McCormick, M., Frank, D., Trouet, V., Kaplan, J.O., Herzig, F., Heussner, K.-U., Wanner, H., Luterbacher, J., Esper, J., 2011. 2500 Years of European Climate Variability and Human Susceptibility. Science 331, 578-582.

Büntgen, U., Myglan, V.S., Ljungqvist, F.C., McCormick, M., Di Cosmo, N., Sigl, M., Kaplan, J.O., de Vaan, M.A.C., Luterbacher, J., Wacker, L., Tegel, W., Kirdyanov, A.V., 
2016. Cooling and societal change during the Late Antique Little Ice Age from 536 to around 660 AD. Nature Geoscience.

Burrows, C.J., 1973. Studies on some glacial moraines in New Zeland-2: Ages of moraines of the Mueller, Hooker, and Tasman glaciers (S79). New Zealand journal of geology and geophysics 16(4), 831-856.

Bushueva, I.S., Solomina, O.N., 2012. Fluctuations of Kashkatash glacier in XVII-XXI by carthographic, dendrochronological and lichenonemtric data. Ice and Snow 118(2), $121-130$.

Carlson, A.E., Stoner, J.S., Donnelly, J.P., Hillaire-Marcel, C., 2008. Response of the southern Greenland Ice Sheet during the last two deglaciations. Geology 36, 359-362, doi: 10.1130/G24519A.

Caseldine, C.J., 1987. Neoglacial glacier variations in northern Iceland: Examples from Eyjafjörður area. Arctic and Alpine Research 19, 296-304.

Caseldine, C.J., Stötter, J., 1993. "Little Ice Age" glaciation of Tröllaskagi Peninsula, northern Iceland: climatic implications for reconstructed equilibrium-line altitudes (ELAs). The Holocene 3, 357-366.

Chenet, M., Roussel, E., Jomelli, V., Grancher, D., 2010. Asynchronous Little Ice Age glacial maximum extent in southeast Iceland. Geomorphology 114, 253-260. 
Chinn, T., Winkler, S., Salinger, M.J., Haakensen, N., 2005. Srecent glacier advances in Norway and New Zealand: A comparison of their glaciological and meteorological causes. Geograf. Annal. A, 87A, 141-157.

Chinn, T.J.N., Fitzharris, B.B., Willsman, A., Salinger, M.J., 2012. Annual ice volume changes 1976-2008 for the New Zealand Southern Alps. Global Planet Change 92-93, $105-118$.

Clague, J.J., Koch, J., Geertseman, M., 2010. Expansion of outlet glaciers of the Juneau Icefield in northwest British Columbia during the past two millennia. The Holocene 20, $447-461$.

Clapperton, C.M., 1983. The glaciation of the Andes. Quaternary Science Reviews 2, 83155.

Cook, E.A., Palmer J.G., D’Arrigo, R. 2002. Evidence for a 'Medieval Warm Period' in a 1,100 year tree-ring reconstruction of past austral summer temperatures in New Zealand. Geophysical Research Letters 29(14), 121-124 , DOI: 10.1029/2001GL014580.

Coulthard, B., Smith, D.J., Lacourse, T., 2012. Dendroglaciological investigations of mid- to late-Holocene glacial activity in the Mt. Waddington area, British Columbia Coast Mountains, Canada. The Holocene 23, 93-103.

Craig, J.A., Smith, D.J., 2013. Late Holocene glacial history of Scimitar Glacier, Mt. Waddington area, British Columbia Coast Mountains, Canada. Canadian Journal of Earth Sciences 50, 1195-1208. 
Dahl, S.O., Nesje, A., 1994. Holocene glacier fluctuations at Hardangerjøkulen, centralsouthern Norway: a high resolution composite chronology from lacustrine and terrestrial deposits. The Holocene 4, 269-277.

Dahl, S.O., and Nesje, A., 1996. A new approach to calculating Holocene winter precipitation by combining glacier equilibrium-line altitudes and pine-tree limits: a case study from Hardangerjøkulen, central southern Norway. The Holocene 6, 381-398.

Dahl, S.O., Bakke, J., Lie, Ø., Nesje, A., 2003. Reconstruction of former glacier equilibrium-line altitudes based on proglacial sites: an evaluation of approaches and selection of sites. Quaternary Science Reviews 22, 275-287.

Daigle, T. A., and Kaufman, D. S. 2009. Holocene climate inferred from glacier extent, lake sediment and tree rings at Goat Lake, Kenai Mountains, Alaska, USA. Journal of Quaternary Science, 24(1), 33-45.

Deline, P., Orombelli, G., 2005. Glacier fluctuations in the western Alps during the Neoglacial, as indicated by the Miage morainic amphitheatre (Mont Blanc massif, Italy). Boreas 34, 456-467.

Denton, G.H., and Broecker, W.S., 2008. Wobbly ocean conveyor circulation during the Holocene? Quaternary Science Reviews 27, 1939-1950.

Desilets, D., Zreda, M., Almasi, P. F., \& Elmore, D. (2006). Determination of cosmogenic $36 \mathrm{Cl}$ in rocks by isotope dilution: innovations, validation and error propagation. Chemical Geology, 233(3), 185-195.

Dolezal, J., Altman, J., Vetrova, V.P., Hara, T., 2014. Linking two centuries of tree growth and glacier dynamics with climate changes in Kamchatka. Climatic Change 124, 207220, DOI 10.1007/s10584-014-1093-4. 
Dolgova, E. 2016. June-September temperature reconstruction in the Northern Caucasus based on blue intensity data. Dendrochronologia, 39, 17-23.

Dortch, J.M., Owen, L.A., Caffee, M.W., 2013. Timing and climatic drivers for glaciation across semi-arid western Himalayan-Tibetan orogen. Quaternary Science Reviews 78, 188-208.

Dunai, T. J., 2001. Reply to comment on 'Scaling factors for production rates of in situ produced cosmogenic nuclides: a critical reevaluation'by Darin Desilets, Marek Zreda and Nathaniel Lifton. Earth and Planetary Science Letters, 188(1), 289-298.

Espizua, L.E., and Pitte, P., 2009. The Little Ice Age in the Andes of Mendoza, Argentina. Palaeogeography, Palaeoclimatology, Palaeoecology 281, 345-350.

Fenton, C.R., Hermanns, R.L., Blikra, L.H., Kubik, P.W., Bryant, C., Niedermann, S., Meixner, A., Goethals, M.M., 2011. Regional 10Be production rate calibration for the past $12 \mathrm{ka}$ deduced from the radiocarbon-dated Grøtlandsura and Russens rock avalanches at $69^{\circ} \mathrm{N}$, Norway. Quaternary Geochronology 6, 437-452.

Flowers, G.E., Björnsson, H., Geirsdóttir, Á., Miller, G.H., Clarke, G.K.C., 2007. Glacier fluctuation and inferred climatology of Langjökull ice cap through the Little Ice Age. Quaternary Science Reviews 26, 2337-2353.

Flowers, G.E., Björnsson, H., Geirsdóttir, Á., Miller, G.H., Clarke, G.K., 2008. The Holocene history of Langjökull ice cap from physical modelling and empirical evidence. Quaternary Science Reviews 27, 797-813.

Forman, S.L., and Weihe, R.R., 2000. The Holocene occurrence of reindeer on Franz Josef Land, Russia. The Holocene 10(6), 763-768. 
Forman, S.L., Lubinski, D.J., Zeeberg, J.J., Polyak, L., 1999. Postglacial emergence and Late Quaternary glaciation on northern Novaya Zemlya, Arctic Russia. Boreas 28, 133145.

Furrer, G., 1992. Zur Gletschergeschichte des Liefdefjords. Stuttgarter Geographische Studien 117, 267-78.

Furrer, G., Stapfer, A., Glaser, U., 1991. Zur nacheiszeitlichen Gletschergeschichte des Liefdefjords (Spitzbergen) (Ergebnisse der Geowissenschaftlichen Spitzbergenexpedition 1990). Geogr. Helv. 1991, 147-155.

Geirsdóttir, Á., Miller, G.H., Wattrus, N.J., Björnsson, H., Thors, K. 2008. Stabilization of glaciers terminating in closed water bodies: Evidence and broader implications. Geophysical Research Letters 35, L17502, doi:10.1029/2008GL034432.

Geirsdóttir, Á., Miller, G.H., Axford, Y., Ólafsdóttir, S., 2009. Holocene and latest Pleistocene climate and glacier fluctuations in Iceland. Quaternary Science Reviews 28(21-22), 2107-2118.

Geirsdóttir, Á., Miller, G.H., Larsen, D.J., Ólafsdóttir, S., 2013. Abrupt Holocene climate transitions in the northern North Atylantic region recorded by synchronized records in Iceland. Quaternary Science Reviews 70, 48-62.

Geirsdóttir, Á., Miller, G.H., Larsen, D.J., 2015. Glacial landforms in Hvítárvatn, central Iceland. In: Dowdeswell, J.A., Canals, M., Jakobsson, M., Todd, B.J., Dowdeswell, E.K., Hogan, K.A. (eds.). Atlas of Submarine Glacial Landforms: Modern, Quaternary and 
Ancient. Geological Society, London, Memoirs, 1-4. The Geological Society of London, 2014.

Gellatly, A.F., Chinn, T.J.H., Röthlisberger, F., 1988. Holocene glacier variations in New Zealand. Quaternary Sciences Review 7, 227-242.

Glasser, N.F., Hambrey, M.J., Aniya, M., 2002. An advance of Soler Glacier, North Patagonian Icefield, at ca. AD 1222-1342. The Holocene 12, 113-120.

Glasser, N.F., Harrison, S., Aniya, M., Winchester, V., 2004. Late Pleistocene and Holocene palaeoclimate and glacier fluctuations in Patagonia. Global and Planetary Change 43(1-2), 79-101.

Glasser, N.F., Harrison, S., Jansson, K.N., Anderson, K., Cowley, A., 2011. Global sealevel contribution from the Patagonian Icefields since the Little Ice Age maximum. Nature Geoscience 4(5), 303-307.

Goehring, B. M., Lohne, Ø. S., Mangerud, J., Svendsen, J. I., Gyllencreutz, R., Schaefer, J., \& Finkel, R. 2012. Late glacial and holocene 10Be production rates for western Norway. Journal of Quaternary Science, 27(1), 89-96.

Goodman, A.Y., Rodbell, D.T., Seltzer, G.O., Mark, B.G., 2001. Subdivision of glacial deposits in southeastern Peru based on pedogenic development and radiometric Ages. Quaternary Research 56, 31-50.

Gosse, J.C., and Phillips, F.M., 2001. Terrestrial in situ cosmogenic nuclides: theory and application. Quaternary Science Reviews 20, 1475-1560. 
Granger, D.E., Lifton, N.A., Willenbring, J.K., 2013. A cosmic trip: 25 years of cosmogenic nuclides on geology. Geological Society of America Bulletin 125, 13791402.

Grosjean, M., Suter, P.J., Trachsel, M., Wanner, H., 2007. Ice-borne prehistoric finds in the Swiss Alps reflect Holocene glacier fluctuations. Journal of Quaternary Science 22, 203-207.

Grove, J.M., 2001. The initiation of the "Little Ice Age" in regions round the North Atlantic. Climatic Change 48, 53-82.

Grove, J.M., 2004. Little Ice Ages: Ancient and Modern. Second edition. London and New York: Routledge, 2 vols.

Grudd, H., Briffa, K. R., Karlén, W., Bartholin, T. S., Jones, P. D., \& Kromer, B., 2002. A 7400-year tree-ring chronology in northern Swedish Lapland: natural climatic variability expressed on annual to millennial timescales. The Holocene, 12(6), 657-665.

Guilizzoni, P., Marchetto, A., Lami, A., Brauer, A., Vigliotti, L., Musazzi, S., Langone, L., Manca, M., Lucchini, F., Calanchi, N., Dinelli, E., Mordenti, A., 2006. Records of environmental and climatic changes during the late Holocene from Svalbard: palaeolimnology of Kongressvatnet. Journal of Paleolimnology 36, 325-351.

Hafner, A., 2012. Archaeological Discoveries on Schnidejoch and at Other Ice Sites in the European Alps. Arctic 65, Suppl. 1, 189-202. 
Hall, B.L., Baroni, C., Denton, G.H., 2008. The most extensive Holocene advance in the Stauning Alper, East Greenland, occurred in the Little Ice Age. Polar Research 27, 128134.

Hall, S. R., Farber, D. L., Ramage, J. M., Rodbell, D. T., Finkel, R. C., Smith, J. A., Mark, B.G. \& Kassel, C., 2009. Geochronology of Quaternary glaciations from the tropical Cordillera Huayhuash, Peru. Quaternary Science Reviews, 28(25), 2991-3009.

Harington, C.R. (ed.), 1992. 1816. The Year Without a Summer? Canadian Museum of Nature, Ottawa.

Harrison, S., Winchester, V., 1998. Historical fluctuations of the Gualas and Reicher glaciers, North Patagonian Icefield, Chile. The Holocene 8(4), 481-485.

Harrison, S., Winchester, V., 2000. Nineteenth and Twentieth century glacier fluctuations and climatic implications in the Arco and Colonia Valleys, Hielo Patagónico Norte, Chile. Arctic, Antarctic and Alpine Research 32(1), 55-63.

Harrison, S., Winchester, V., Glasser, N.F., 2007. The timing and nature of recession of outlet glaciers of Hielo Patagónico Norte, Chile, from their Neoglacial IV (Little Ice Age) maximum positions. Global and Planetary Change 59, 67-78.

Harrison, S., Glasser, N., Winchester, V., Haresign, E., Warren, C., Duller, G.A.T., Bailey, R., Ivy-Ochs, S., Jansson, K., Kubik, P., 2008. Glaciar León, Chilean Patagonia: lateHolocene chronology and geomorphology. The Holocene 18(4), 643-652.

Hastenrath, S., 1981. The glaciation of the Ecuatorian Andes, Rottermam, Balkema. 
Henderson, K.A., 2002. An ice core paleoclimate study of Windy Dome, Franz Josef Land, Russia: development of a recent climate history for the Barents Sea. The Ohio state University. Columbus, Ohio.

Hewitt, K., 1988. Catastrophic landslide deposits in the Karakoram Himalaya. Science 242, 64-77.

Hochreuther, P., Loibl, D., Wernicke, J., Zhu, H., Grießinger, J., Bräuning, A., 2015. Ages of major Little Ice Age glacier fluctuations on the southeast Tibetan Plateau derived from tree-ring-based moraine dating. Palaeogeography, Palaeoclimatology, Palaeoecology 422, $1-10$.

Hoelzle, M., Haeberli, W., Dischl, M., Peschke, W., 2003. Secular Secular glacier mass balances derived from cumulative glacier length changes. Global and Planetary Change, $36,4,295-306$.

Hoffman, K.M. and Smith, D.J., 2013. Late Holocene glacial activity at Bromley Glacier, Cambria Icefield, northern British Columbia Coast Mountains, Canada. Canadian Journal of Earth Sciences 50, 599-606.

Holmlund, P. and Fuenzalida, H.,1995. Anomalous Glacier responses to 20th century climatic changes in Darwin Cordillera, Southern Chile. Journal of Glaciology 41(139), $465-473$.

Holocene and Latest Pleistocene Alpine Glacier Fluctuations: A Global Perspective. 2009. Quaternary Science Reviews, 28(21). 
Holzhauser, H., Magny, M., Zumbühl, H.J., 2005. Glacier and lake-level variations in west-central Europe over the last 3500 years. Holocene 15 (6), 789-801.

Hormes, A., Müller, B.U., Schlüchter, C., 2001. The Alps with little ice: evidence for eight Holocene phases of reduced glacier extent in the Central Swiss Alps. The Holocene $11,255-265$.

Hormes, A., Beer, J., Schlüchter, C., 2006. A geochronological approach to understanding the role of solar activity on Holocene glacier length variability in the Swiss Alps. Geografiska Annaler: Series A, Physical Geography 88, 281-294.

Hu, F.S., Ito, E., Brown, T. A., Curry, B.B., Engstrom, D.R., 2001. Pronounced climatic variations during the last two millennia in the Alaska Range. Proceedings of the National Academy of Sciences USA 98, 10552-10556.

Hughes, A.L.C., Rainsley, E., Murray, T., Fogwill, C.J., Schnabel, C., Xu, S., 2012. Rapid response of Helheim Glacier, southeast Greenland, to early Holocene climate warming. Geology 40, 427-430, doi:10.1130/G32730.1.

Humlum, O., Christiansen, H.H., 2008. Geomorphology of the Ammassalik Island,SE Greenland. Geografisk Tidsskrift-Danish Journal of Geography 108 (1), 5-20.

Humlum, O., Elberling, B., Hormes, A., Fjordheim, K., Hansen, O.H., Heinemeier, J., 2005. Late-Holocene glacier growth in Svalbard, documented by subglacial relict vegetation and living soil microbes. Holocene 15, 396-407. 
Huss, M., Bauder, A., Funk, M., Hock, R., 2008. Determination of the seasonal mass balance of four Alpine glaciers since 1865. Journal of Geophysical Research 113(F1), F01015, doi:10.1029/2007JF000803.

Imhof, P., 2010. Glacier fluctuations in the Italian Mont Blanc massif from the Little Ice Age until the present. Historical reconstructions for the Miage, Brenva and Pré-de-Bard Glacierst. M.Sc. Thesis. Geographisches Institut der Universität, Bern, 132 PP.

Imhof, P., Nesje, A., Nussbaumer, S.U., 2012. Climate and glacier fluctuations at Jostedalsbreen and Folgefonna, southwestern Norway and in the western Alps from the 'Little Ice Age' until the present: The influence of the North Atlantic Oscillation. The Holocene 22, 235-247.

IPCC, 2013. Climate Change 2013: The Physical Science Basis. Contribution of Working Group I to the Fifth Assessment Report of the Intergovernmental Panel on Climate Change. [Stocker, T.F., D. Qin, G.-K. Plattner, M. Tignor, S. K. Allen, J. Boschung, A. Nauels, Y. Xia, V. Bex and P.M. Midgley (eds.)]. Cambridge University Press, Cambridge, United Kingdom and New York, NY, USA.

Ivy-Ochs, S., Kerschner, H., Maisch, M., Christl, M., Kubik, P.W., Schluechter, C., 2009. Latest Pleistocene and Holocene glacier variations in the European Alps. Quaternary Science Reviews 28, 2137-2149.

Jackson, S., Laxton, S.C., Smith, D.J., 2008. Dendroglaciological evidence for Holocene glacial advances in the Todd Icefield area, northern British Columbia Coast Mountains. Canadian Journal of Earth Sciences 45, 83-98. 
Joerin, U.E., Stocker, T.F., Schlüchter, C., 2006. Multicentury glacier fluctuations in the Swiss Alps during the Holocene. The Holocene 16, 697-704.

Johnson, K., Smith, D.J., 2012. Dendroglaciological reconstruction of late-Holocene glacier activity at White and South Flat Glaciers, Boundary Range, northern British Columbia Coast Mountains, Canada. The Holocene 22, 984-992.

Jomelli, V., Grancher, D., Naveau, P., Cooley, D. 2007. Assessment study of lichenometric methods for dating surface. Geomorphology 86, 131-143.

Jomelli, V., Favier, V., Rabatel, A., Hoffmann, G., Brunstein, D., Francou, B. 2009. Fluctuations of Andean tropical glaciers since the last millennium and palaeoclimatic implication: a review. Palaleogeography, Palaleo climatology Palaleoecology, 281, 269282.

Jomelli, V., Khodri, M., Favier, V., Brunstein, D., Ledru, M.P., Wagnon, P., Blard, P.H., Sicart, J.E., Braucher, R., Grancher, D., Bourlès, D., Braconnot, P., Vuille, M., 2011. Irregular tropical glacial retreat during the Holocene driven by progressive warming. Nature 474, 196-199.

Jomelli, V., Favier, V., Vuille, M., Braucher, R., Martin, L., Blard P-H., Colose C., Brunstein, D., He, F., Khodri, M., Bourlès, D., Leanni, L., Rinterknecht, V., Grancher, D., Francou, B., Ceballos, J.L., Francesca, H., Liu, Z., Otto-Bliesner, B., 2014. A major advance of tropical Andean glaciers during the Antarctic Cold Reversal. Nature 513(7517), 224-228, doi: 10.1038/nature13546. 
Kaplan, M.R., Strelin, J.A., Schaefer, J.M., Denton, G.H., Finkel, R.C., Schwartz, R., Putnam, A.E., Vandergoes, M.J., Goehring, B.M., Travis, S.G., 2011. In-situ cosmogenic 10Be production rate at Lago Argentino, Patagonia: implications for late-glacial climate chronology. Earth and Planetary Science Letters 309, 21-32.

Karlén, W., 1976. Lacustrine sediments and tree-limit variations as indicators of Holocene climatic fluctuations in Lapland: Northern Sweden. Geografiska Annaler 58A, $1-34$.

Karlén, W., 1988. Scandinavian glacial and climatic fluctuations during the Holocene. Quaternary Science Reviews 7, 199-209.

Karlén, W., and Kuylenstierna, J. 1996. On solar forcing of Holocene climate: evidence from Scandinavia. The Holocene, 6(3), 359-365.

Karlén, W., and Matthews, J.A., 1992. Reconstructing Holocene glacier variations from glacial lake sediments: studies from Nordvestlandet and Jostedalsbreen-Jotunheimen, southern Norway. Geografiska Annaler 74, 327-348.

Karlen, W., Fastook, J.L., Holmgren, K., Malmstroem, M., Matthews, J.A., Odada, E., Risberg, J., Rosquist, G., Sandgren, P., Shemesh, A., Westerberg L.-O., 1999. Glacier fluctuations on Mount Kenia since ca 6000 cal.years BP: implications for Holocene climatic change in Africa. Ambio 28(5), 409-418.

Kaser, G., Osmaston, H., 2001. Tropical glaciers, Cambridge, University Press. 
Kelley, S.E., Briner, J.P., Young, N.E., Babonis, G.S., Csatho, B., 2012. Maximum late Holocene extent of the western Greenland Ice Sheet during the late 20th century. Quaternary Science Reviews 56, 89-98.

Kelly, M.A., Lowell, T.V., Hall, B.L., Schaefer, J.M., Goehring, B.M., Alley, R.B., Denton, G.H., 2008. A 10Be chronology of late-glacial and Holocene mountain glaciation in the Scoresby Sund region, east Greenland: Implications for seasonality during lateglacial time. Quaternary Science Reviews 27, 2273-2282.

Kelly, M.A., Lowell, T.V., 2009. Fluctuations of local glaciers in Greenland during latest Pleistocene and Holocene time. Quaternary Science Reviews 28, 2088-2106.

Kelly, M.A., Lowell, T.V., Applegate, P.J., Phillips, F.M., Schaefer, J.M., Smith, C.A., Kim, H., Leonard, K.C., Hudson, A.M., 2013. A locally calibrated, late glacial 10Be production rate from a low-latitude, high-altitude site in the Peruvian Andes. Quaternary Geochronology, doi 10.1016/j.quageo.2013.10.007.

Kirkbride, M.P., Dugmore, A.J., 2001. Timing and significance of mid-Holocene glacier advances in northern and central Iceland. Journal of Quaternary Science 16, 145-153.

Kirkbride, M.P., Dugmore, A.J., 2006. Responses of mountain lee caps in central Iceland to Holocene climate change. Quaternary Science Reviews 25, 1692-1707.

Kirkbride, M.P., and Dugmore, A.J., 2008. Two millennia of glacier advances from southern Iceland dated by tephrochronology. Quaternary Research 70, 398-411. 
Kirkbride, M. P., and Winkler, S. (2012). Correlation of Late Quaternary moraines: impact of climate variability, glacier response, and chronological resolution. Quaternary Science Reviews, 46, 1-29.

Knudsen, N.T., Nørnberg, P., Yde, J.C., Hasholt, B., Heinemeier, J., 2008. Recent marginal changes of the Mittivakkat Glacier, Southeast Greenland and the discovery of remains of reindeer (Rangifer tarandus), polar bear (Ursus maritimus) and peaty material. Geografisk Tidsskrift-Danish Journal of Geography 108(1), 137-142.

Koch, J., and Kilian, R., 2005. "Little Ice Age” glacier fluctuations, Gran Campo Nevado, southernmost Chile. The Holocene 15, 20-28.

Koch, J., Osborn, G., Clague, J.J., 2007a. Pre-Little Ice Age glacier fluctuations in Garibaldi Provincial Park, southern Coast Mountains, British Columbia, Canada. The Holocene 17, 1069-1078.

Koch, J., Clague, J.J., Osborn, G., 2007b. Glacier fluctuations during the last millennium in Garibaldi Provincial Park, southern Coast Mountains, British Columbia. Can. Journal Earth Sci. 44, 1215-1233.

Koch, J., Menounos, B.P., Clague, J.J., 2009. Glacier change in Garibaldi Provincial Park, Southern Coast Mountains, British Columbia, since the Little Ice Age. Global and Planetary Change 66, 161-178.

Koch, J., and Clague, J.J., 2011. Extensive glaciers in northwest North America during Medieval time. Climatic Change 107, 593-613. 
Koch, J., Clague, J.J., Osborn, G., 2014. Alpine glaciers and permanent ice and snow patches in western Canada approach their smallest sizes since the mid-Holocene, consistent with global trends. The Holocene 24, 1639-1648.

Koehler, L., and Smith, D.J., 2011. Late Holocene glacial activity in Manatee Valley, southern Coast Mountains, British Columbia, Canada. Canadian Journal of Earth Sciences 48, 603-618.

Koerner, R. M., 2005. Mass balance of glaciers in the Queen Elizabeth Islands, Nunavut, Canada. Annals of Glaciology, 42(1), 417-423.

Kuhn, M., 1989. The response of the equilibrium line altitude to climatic fluctuations: theory and observations. In: Oerlemans, J. (ed.) Glacier fluctuations and climatic change. Kluwer Academic Publishers, Dordrecht, 407-417.

Kutuzov, S., and Shahgedanova, M., 2009. Glacier retreat and climatic variability in the eastern Terskey-Alatoo, inner Tien Shan between the middle of the 19th century and beginning of the 21st century. Global and Planetary Change 69, 59-70.

Kuylenstierna, J.L., Rosqvist, G.C., Holmlund, P., 1996. Late-Holocene glacier variations in the Cordillera Darwin, Tierra del Fuego, Chile. The Holocene 6, 353-58.

Ladurie, E. L. R., 1971. Times of feast, times of famine: a history of climate since the year 1000. Doubleday.

Lal, D., 1991. Cosmic ray labeling of erosion surfaces: in situ nuclide production rates and erosion models. Earth Planet. Sci. Lett. 104, 429-439.

Lamb, H. H. (1965). The early medieval warm epoch and its sequel. Palaeogeography, Palaeoclimatology, Palaeoecology, 1, 13-37. 
Langdon, P.G., Caseldine, C.J., Croudace, I.W., Jarvis, S., Wastegaard, S., Crowford., T.C., 2011. A chironomid-based reconstruction of summer temperatures in NW Iceland since AD 1650. Quaternary Research, 75(3), 451-460.

Larsen, D., Miller, G.H., Geirsdóttir, Á., 2011. A 3000-year varved record of glacial activity and climate change from the proglacial lake Hvítárvatn, Iceland. Quaternary Science Reviews 30, 2715-2731, doi:10.1016/j.quascirev.2011.05.026.

Larsen, D.J., Miller, G.H., Geirsdóttir, Á., 2013. Asynchronous Little Ice Age glacier fluctuations in Iceland and European Alps linked to shifts in subpolar North Atlantic circulation. Earth and Planetary Science Letters 380, 52-59.

Larsen, D.J., Geirsdóttir, Á., Miller, G.H., 2015. Precise chronology of Little Ice Ageexpansion and repetitive surges of Langjökull, central Iceland. Geology. 43(2), 167170. doi: 10.1130/G36185.1

Le Roy, M., Nicolussi, K., Deline, P., Astrade, L., Edouard, J.L., Miramont, C., Arnaud, F., 2015. Calendar-dated glacier variations in the Western European Alps during the Neoglacial: the Mer de Glace record, Mont Blanc massif. Quaternary Science Reviews $108,1-22$.

Leclercq, P.W., Oerlemans, J., 2011. Global and hemispheric temperature reconstruction from glacier length fluctuations. Clim. Dyn. DOI 10.1007/s00382-011-1145-7

Leclercq, P.W., Pitte, P., Giesen, R.H., Masiokas, M.H., Oerlemans, J., 2012. Modelling and climatic interpretation of the length fluctuations of Glaciar Fr'1as (north Patagonian 
Andes, Argentina) 1639-2009AD. Clim. Past 8, 1385-1402, www.climpast.net/8/1385/2012/ doi:10.5194/cp-8-1385-2012.

Lemke, P., Ren, J., Alley, R.B., Allison, I., Carrasco, J., Flato, G., Fujii, Y., Kaser, G., Mote, P., Thomas R.H., and Zhang T., 2007. Observations: Changes in snow, ice and frozen ground. In: Climate Change 2007: The Physical Science Basis. Contribution of Working Group I to the Fourth Assessment Report of the Intergovernmental Panel on Climate Change [Solomon, S., D. Qin, M. Manning, Z. Chen, M. Marquis, K. B. Averyt, M. Tignor and H. L. Miller (eds.)] Cambridge University Press, Cambridge, United Kingdom and New York, NY, USA, pp. 337-383.

Levy, L.B., Kaufman, D.S., Werner, A., 2004. Holocene glacier fluctuations, Waskey Lake, northeastern Ahklun Mountains, southwestern Alaska. The Holocene 14(2), 185193.

Levy, L.B., Kelly, M.A., Lowell, T.V., Hall, B.L., Hempel, L.L., Honsaker, W.M., Lusas, A.R., Howley, J.A., Axford , Y.L., 2014. Holocene fluctuations of Bregne ice cap, Scoresby Sund, east Greenland: a proxy for climate along the Greenland Ice Sheet margin. Quaternary Science Reviews 92, 357-368.

Licciardi, J.M., Schaefer, J.M., Taggart, J.R., Lund, D.C., 2009. Holocene glacierfluctuations in the Peruvian Andes indicate northern climate linkages. Science 325, $1677-1679$.

Lie, Ø., Dahl, S.O., Nesje, A., Matthews, J.A., Sandvold, S., 2004. Holocene fluctuations of a polythermal glacier in high-alpine eastern Jotunheimen, central southern Norway. Quaternary Science Reviews 23, 1925-1945.

Liestøl, O., 1988. The glaciers of the Kongsfjorden area, Spitsbergen. Norsk Geografisk Tidsskrift 42, 231-38. 
Lifton, N., Smart, D. F., Shea, M. A., 2008. Scaling time-integrated in situ cosmogenic nuclide production rates using a continuous geomagnetic model. Earth and Planetary Science Letters, 268(1), 190-201.

Lifton, N., Sato, T., Dunai, T.J., 2014. Scaling in situ cosmogenic nuclide production rates using analytical approximations to atmospheric cosmic-ray fluxes. Earth Planet Sci. Lett. 386, 149-160. http://dx.doi.org/10.1016/j.eps1.2013.10.052.

Lloyd, J.M., 2006. Late Holocene environmental change in Disko Bugt, west Greenland: interaction between climate, ocean circulation and Jakobshavn Isbræ. Boreas 35, 35-49.

Lockwood, M., 2012. Solar Influence on Global and Regional Climates. Surv. Geophys 33, 503-534. DOI 10.1007/s10712-012-9181-3.

Loibl, D., Hochreuther, P., Schulte, P., Hülle, D., Zhu, H., Bräuning, A., Lehmkuhl, F., 2015. Toward a late Holocene glacial chronology for the eastern Nyainqêntanglha Range, southeastern Tibet. Quaternary Science Reviews 107, 243-259.

Lotter, A.F., Ammann, B., Sturm, M., 1992. Rates of change and chronological problems during the late-glacial period. Climate Dynamics 6, 233-239.

Lowell, T.V., Hall, B.L., Kelly, M.A., Bennike, O., Lusas, A.R., Honsaker, W., Smith, C.A., Levy, L.B., Travis, S., Denton, G.H., 2013. Late Holocene expansion of Istorvet ice cap, Liverpool Land, east Greenland. Quaternary Science Reviews 63, 128-140.

Lubinski, D.J., Forman, S.L, Miller, G.H., 1999. Holocene glacier and climate fluctuations on Franz Josef Land, Arctic Russia, 80 N. Quaternary Science Reviews 18(1), 85-108. 
Luckman, B., 1986, Reconstrucion of Little Ice Age events in the Canadian Rockies Mountains. Geographie Physique et Quaternaire 40, 7-28.

Luckman, B.H., 1995. Calendar-dated, early 'Little Ice Age' glacier advance at Robson Glacier, British Columbia, Canada. The Holocene 5, 149-159.

Luckman, B.H., 2000. Little Ice Age in the Canadian Rockies. Geomorphology 32, 357 384.

Luckman, B., 1996. Dendroglaciolgy at Peyto glacier, Alberta. In: Dean, J.S., Meko, D.M., Swetnam, T.W. (eds.). Tree Rings, Environment and Humanity. Radiocarbon, 1995. Tucson, 679-688.

Luckman, B.H., Villalba, R., 2001. Assessing the synchroneity of glacier fluctuations in the western cordillera of the Americas during the last millennium. In: Markgraf, V., (ed.), Interhemispheric climate linkages. Academic Press, London, 119-40.

Luckman, B.H., Wilson, R.J.S., 2005. Summer temperatures in the Canadian Rockies during the past millennium: a revised record. Climate Dynamics 24, 131-144.

Lüthi, M.P., 2014. Little Ice Age climate reconstruction from ensemble reanalysis of Alpine glacier fluctuations The Cryosphere, 8, 639-650, www.thecryosphere.net/8/639/2014/ doi:10.5194/tc-8-639-2014.

MacGregor, K.R., Riihimaki, C.A., Myrbo, A., Shapley, M.D., Jankowski, K., 2011. A Geomorphic and climatic change over the past $12,900 \mathrm{yr}$ at Swiftcurrent Lake, Glacier National Park, Montana, USA. Quaternary Research 75, 80-90. 
Maisch, M., A. Wipf, B. Denneler, J. Battaglia, Benz, C., 2000. Die Gletscher der

Schweizer Alpen: Gletscherhochstand 1850, Aktuelle Vergletscherung, Gletscherschwund Szenarien. 2d ed. Zurich: VdF Hochschulverlag.

Malone, A.G.O., Pierrehumbert, R.T., Lowell, T.V., Kelly, M.A., Stroup, J.S., 2015.

Constraints on southern hemisphere tropical climate change during the Little Ice Age and Younger Dryas based on glacier modeling of the Quelccaya Ice Cap, Peru. Quaternary Science Reviews 125, 106-116.

Mangerud, J., Landvik, J.Y., 2007. Younger Dryas cirque glaciers in western Spitsbergen: smaller than during the Little Ice Age. Boreas 36, 278-285.

Margreth, A., Dyke, A.S., Gosse, J.C., Telka, A.M., 2014. Neoglacial ice expansion and late Holocene cold-based ice cap dynamics on Cumberland Peninsula, Baffin Island, Arctic Canada. Quaternary Science Reviews 91, 242-256.

Martin, L.C.P., Blard P.-H., Lave, J., Braucher R., Lupker, M., T. Condom, T., Charreau, J., Mariotti, V., ASTER Team, Davy, E., 2015. In situ cosmogenic 10Be production rate in the High Tropical Andes. Quaternary Geochronology 30(2015), 54-68.

Marzeion, B., and Nesje, A., 2012. Spatial patterns of North Atlantic Oscillation influence on mass balance variability of European glaciers. The Cryosphere 6, 661-673.

Marzeion, B., Cogley, J.G., Richter, K., Parkes, D., 2014. Attribution of global glacier mass loss to anthropogenic and natural causes / http://www.sciencemag.org/content/early/recent 10.1126/science.1254702 
Masiokas, M.H.; Villalba, R.; Luckman, B.; Delgado, S.; Lascano, M.; Stepanek, P., 2008. 20th-century glacier recession and regional hydroclimatic changes in northwestern Patagonia. Global and Planetary Change 60(1-2), 85-100.

Masiokas, M.H., Rivera, A., Espizua, L.E., Villalba, R., Delgado, S., Aravena, J.C., 2009a. Glacier fluctuations in extratropical South America during the past 1000 years. Palaeogeography, Palaeoclimatology, Palaeoecology 281, 242-268.

Masiokas, M.H., Luckman, B., Villalba, R., Delgado, S., Skvarca, P., Ripalta, A., 2009b. Little Ice Age fluctuations of small glaciers in the Monte Fitz Roy and Lago del Desierto areas, south Patagonian Andes, Argentina. Palaeogeography, Palaeoclimatology, Palaeoecology 281, 3-4, 351-362.

Masiokas, M.H., Luckman, B.H., Villalba, R., Delgado, S., Rabassa, J., 2010. Little Ice Age fluctuations of Glaciar Río Manso in the north Patagonian Andes of Argentina. Quaternary Research 73(1), 96-106.

Matthews, J.A., 2005. 'Little Ice Age' glacier variations in Jotunheimen, southern Norway: a study in regionally controlled lichenometric dating of recessional moraines with implications for climate and lichen growth curves. The Holocene 15, 1-19.

Matthews, J.A., 2007. Neoglaciation in Europe. In: Elias, S. (ed.). Encyclopedia of Quaternary Science. Amsterdam: Elsevier, 1122-1133.

Matthews, J.A., and Dresser, P.Q., 1983. Intensive 14C dating of a buried palaeosol horizon. Geologiska Föreningen i Stockholm Förhandlingar 105, 59-63. 
Matthews, J.A., and Briffa, K.R., 2005. The 'Little Ice Age': Re-evaluation of an evolving concept. Geografiska Annaler 87A, 17-36.

Matthews, J.A., Dahl, S.O., Nesje, A., Berrisford, M.S., Andersson, C., 2000. Holocene glacier variations in central Jotunheimen, southern Norway based on distal glaciolacustrine sediment cores. Quaternary Science Reviews 19, 1625-1647.

Matthews, J.A., Berrisford, M.S., Dresser, P.Q., Nesje, A., Dahl, S.O., Bjune, A.E., Bakke, J., Birks, H.J.B., Lie, Ø., Dumayne-Peaty, L., Barnett, C., 2005. Holocene glacier history of Bjørnbreen and climatic reconstruction in central Jotunheimen, Norway, based on proximal glaciofluvial stream-bank mires. Quaternary Science Reviews 24, 67-90.

Matthews, J.A., and Dresser, P.Q., 2008. Holocene glacier variation chronology of the Smørstabbtinden massif, Jotunheimen, southern Norway, and the recognition of centuryto millennial-scale European Neoglacial events. The Holocene 18, 181-201.

Maurer, M.K., Menounos, B., Luckman, B.H., Osborn, G., Clague, J.J., Beedle, M.J., Smith, R., Atkinson, N., 2012. Late Holocene glacier expansion in the Cariboo and northern Rocky Mountains, British Columbia, Canada. Quaternary Science Reviews 51, $71-80$.

Mayewski, P.A., and Jeschke, P.A., 1979. Himalayan and Trans-Himalayan glacier fluctuations since AD 1812. Arctic and Alpine Research 11, 267-287. 
Mayewski, P.A., Pregent, G.P., Jeschke, P.A., Ahmad, N., 1980. Himalayan and Trans Himalayan glacier fluctuations and the South Asian Monsoon record. Arctic and Alpine Research 12, 171-182.

McCarthy, D.P., and Luckman, B.H., 1993. Estimating ecesis for tree-ring dating of moraines. a comparative study from the, Canadian Cordillera. Arctic and Alpine Research, 25, 63-68.

McCormick M., Büntgen, U., Cane, M.A., Cook, E.R., Harper, K., Huybers, P., Litt, T., Manning, S.W., Mayewski, P.W., More, A.F.M., Nicolussi K., Tegel, W., 2012. Climate Change during and after the Roman Empire: Reconstructing the Past from Scientic and Historical Evidence. Journal of Interdisciplinary History 43, 169-220.

Meeker, L.D., and Mayewski, P.A., 2002. A 1400-year high-resolution record of atmospheric circulation over the North Atlantic and Asia. Holocene 12(3), 257-266.

Menounos, B., Osborn, G., Clague, J.J., Luckman, B.H., 2009. Latest Pleistocene and Holocene glacier fluctuations in western Canada. Quaternary Science Reviews 28, 20492074.

Mercer, J.H., 1965. Glacier variations in Southern Patagonia. Geographical Review 55, $390-413$.

Mercer, J.H., 1970. Variations of some Patagonian glaciers since the Late-Glacial: II. American Journal of Science 269, 1-25. 
Mercer, J.H., and Palacios, O.M., 1977. Radiocarbon dating of the last glaciation in region Peru. Geology 5(10), 600-604.

Mernild, S.H., Hanna, E., Yde, J.C., Seidenkrantz, M.-S., Wilson, R., Knudsen, N.T., 2014. Atmospheric and oceanic influence on mass balance of northern North Atlantic rtegion land-terminating glaciers. Geografiska Annaler 96A, 561-577.

Miller, G.H., Geirsdottir, A., Zhong, Y., Larsen, D., Otto-Bliesner, B.L., Holland, M.M., Bailey, D.A., Refsnider, K.A., Lehman, S.J., Southon, J.R., Anderson, C., Bjornsson, H., Thordarson, T., 2012. Abrupt onset of the Little Ice Age triggered by volcanism and sustained by sea-ice/ocean feedbacks. Geophysical Research Letters 39, L02708. DOI:10.1029/2011GL050168.

Miller, G.H., Lehman, S.J., Refsnider, K.A., Southon, J.R., Zhong, Y., 2013. Unprecedented recent summer warmth in Arctic Canada. Geophysical Research Letters $40,1-7$.

Moberg, A., Sonechkin, D.M, Holmgren, K., Datsenko, N.M., Karlén, W., 2005. Highly variable Northern Hemisphere temperatures reconstructed from low- and high-resolution proxy data. Nature 433, 613-617.

Molnia, B. F., 2008. Glaciers of Alaska. US Geological Survey professional paper, $(1386 \mathrm{~K})$.

Mood, B.J., Smith, D.J., 2015. Latest Pleistocene and Holocene behaviour of Franklin Glacier, Mt. Waddington area, British Columbia Coast Mountains, Canada. The Holocene 4, doi: 10.1177/0959683615569321. 
Moreno, P.I., Vilanova I., Villa-Martı'nez R., Garreaud, R.D., Rojas, M., Pol-Holz, R. De, 2014. Southern Annular Mode-like changes in southwestern Patagonia at centennial timescales over the last three millennia. Nature Communications DOI: 10.1038/ncomms5375.

Munroe, J.S., Crocker, T.A., Giesche, A.M., Rahlson, L.E., Duran, L.T., Bigl, M.F., Laabs, B.J.C., 2012. A lacustrine-based Neoglacial record for Glacier National Park, Montana, USA. Quaternary Science Reviews 53, 39-54.

Munroe, J.S., Klem, C.M., Bigl, M.F., 2013. A lacustrine sedimentary record of Holocene periglacial activity from the Uinta Mountains, Utah, U.S.A. Quaternary Research 79, 101-109.

Murari, M.K., Owen, L.A., Dortch, J.M., Caffee, M.W., Dietsch, C., Fuchs, M., Haneberg, W.C., Sharma, M.C., Townsend-Small, A., 2014. Timing and climatic drivers for glaciation across monsoon-influenced regions of the Himalayan-Tibetan orogen. Quaternary Science Reviews 88C, 159-182.

Murdmaa, I., Polyak, L., Ivanova, E., Khromova, N., 2004. Paleoenvironments in Russkaya Gavan’ Fjord (NW Novaya Zemlya, Barents Sea) during the last millennium. Palaeogeography, Palaeoclimatology, Palaeoecology 209, 141-154.

Myglan, V.S., Oidupaa, O.Ch., Vaganov, E.A., 2012 a. Construction of 2367 years long tree-ring chronology for the Altay-Sayany region (Mongun-Taiga Mountains). Archeology, ethnology and anthropology of Eurasia 3(51), 76-83. 
Myglan, V.S., Zharnikova, O.A., Malysheva, N.V., Gerasimova, O.V., Vaganov, E.A., Sidorova, O.V., 2012b. Constructing the tree-ring chronology and reconstructing summertime air temperatures in southern Altai for the last 1500 years. Geography and Natural Resources 33(3), 200-207.

Narama, C., 2002. Late Holocene variation of the Raigorodskogo Glacier and climate change in the Pamir-Alai, central Asia. Catena 48, 21-37.

Naveau, P., Jomelli, V., Cooley, D., Grancher, D., Rabatel, A., 2007. Modeling uncertainties in lichenometry studies with an application: The Tropical Andes (Charquini Glacier in Bolivia). Arctic, Antarctic and Alpine Research 39, 277-288.

Nazarov, A.N., Agatova, A.R., 2008. Glacier dynamics of Northern Chuyia Range in the Central Altay in the second half of the Holocene. Materialy of Glaciological Studies 105, 73-86.

Nazarov, A.N., Solomina, O.N., Myglan, V.S., 2012. Variations of the Tree Line and Glaciers in the Central and Eastern Altai Regions in the Holocene. Doklady Earth Sciences 444(2), 787-790.

Nesje, A., 2005. Briksdalsbreen in western Norway: AD 1900-2004 frontal fluctuations as a combined effect of variations in winter precipitation and summer temperature. The Holocene 15, 1245-1252.

Nesje, A., 2009. Latest Pleistocene and Holocene alpine glacier fluctuations in Scandinavia. Quaternary Science Reviews 28, 2119-2136. 
Nesje, A., Dahl, S.O., 1991a. Holocene glacier variations of Blåisen, Hardangerjøkulen, central southern Norway. Quaternary Research 35, 25-40.

Nesje, A., Dahl, S.O., 1991b. Late Holocene glacier fluctuations in Bevringsdalen, Jostedalsbreen region, western Norway (ca 3200-1400 BP). The Holocene 1, 1-7.

Nesje, A., Kvamme, M., 1991. Holocene glacier and climate variations in western Norway: Evidence for early Holocene glacier demise and multiple Neoglacial events. Geology 19, 610-612.

Nesje, A. and Rye, N. 1993. Late Holocene glacier activity at Sandskardfonna, Jostedalsbreen area, western Norway. Norwegian Journal of Geography 47, 21-28.

Nesje, A., Dahl, S.O. 2003. The 'Little Ice Age'—only temperature? Holocene 13, 139145.

Nesje, A., Kvamme, M., Rye, N., Løvlie, R., 1991. Holocene glacial and climate history of the Jostedalsbreen region, western Norway; evidence from lake sediments and terrestrial deposits. Quaternary Science Reviews 10, 87-114.

Nesje, A., Dahl, S.O., Løvlie, R., Sulebak, J., 1994. Holocene glacier activity at the soutwestern part of Hardangerjøkulen, central-southern Norway: evidence from lacustrine sediments. The Holocene 4, 377-382.

Nesje, A., Dahl, S.O., Løvlie, R., 1995a. Late Holocene glacier and avalanche activity in the Ålfoten area, western Norway: evidence from a lacustrine sedimentary record, Norsk Geologisk Tidsskrift 75, 120-126. 
Nesje, A., Johannessen, T., Birks, H.J.B., 1995b. Briksdalsbreen, western Norway: climatic effects on the terminal response of a temperate glacier between AD 1901 and 1994. The Holocene 5, 343-347.

Nesje, A., Dahl, S.O., Andersson, C., Matthews, J.A., 2000a. The lacustrine sedimentary sequence in Sygneskardvatnet, western Norway: a continuous, high-resolution record of the Jostedalsbreen ice cap during the Holocene. Quaternary Science Reviews 19, 10471065.

Nesje, A., Lie, Ø., Dahl, S.O., 2000b. Is the North Atlantic Oscillation reflected in Scandinavian glacier mass balance records? Journal of Quaternary Science 15, 587-601.

Nesje, A., Matthews, J.A., Dahl, S.O., Berrisford, M.S., Andersson, C., 2001. Holocene glacier fluctuations of Flatebreen and winter precipitation changes in the Jostedalsbreen region, western Norway, based on glaciolacustrine records. The Holocene 11, 267-280.

Nesje, A., Bjune, A.E., Bakke, J., Dahl, S.O., Lie, Ø., Birks, H.J.B., 2006. Holocene palaeoclimate reconstructions at Vanndalsvatnet, western Norway, with particular reference to the 8200 cal. yr BP event. The Holocene 16, 717-729.

Nesje, A., Dahl, S.O., Thun, T., Nordli, Ø., 2007. The 'Little Ice Age' glacial expansion in western Scandinavia - summer temperature or winter precipitation? Climate Dynamics $30,789-801$.

Nesje, A., Bakke, J., Dahl, S.O., Lie, Ø., Matthews, J.A., 2008. Norwegian mountain glaciers in the past, present and future. Global and Planetary Change 60, 10-27. 
Nesje, A., Pilo, L.H., Finstad, E., Solli, B., Wangen, V., Odegard, R.S., Isaksen, K., Storen, E.N., Bakke, D.I., Andreassen, L.M., 2012. The climatic significance of artefacts related to prehistoric reindeer hunting exposed at melting ice patches in southern Norway. The Holocene 22(4), 485-496, doi: 10.1177/0959683611425552.

Neukom, R., Luterbacher, J., Villalba, R., Ku“ ttel, M., Frank, D., Jones, P.D., Grosjean, M., Wanner, H., Aravena, J.-C., Black, D.E., Christie, D.A., D’Arrigo, R., Lara, A., Morales, M., Soliz-Gamboa, C., Srur, A., Urrutia, R., von Gunten, L., 2010. Multiproxy summer and winter surface air temperature field reconstructions for southern South America covering the past centuries. Clim. Dyn. DOI 10.1007/s00382-010-0793-3.

Nicolussi, K., Patzelt, G., 2001. Untersuchungen zur holozänen Gletscherentwicklung von Pasterze und Gepatschferner (Ostalpen). Zeitschrift für Gletscherkunde und Glazialgeologie 36, 1-87.

Nicolussi, K., Schlüchter, C., 2012. The 8.2 ka event--Calendar-dated glacier response in the Alps. Geology 40, 819-822, doi: 10.1130/G32406.1.

Nicolussi, K., Jörin, U., Kaiser, K.F., Patzelt, G., Thurner, A., 2006. Precisely dated glacier fluctuations in the Alps over the last four millennia. In: Price, M.F. (ed.): Global Chance in Mountain Regions. Duncow, Sapiens, 59-60.

Nicolussi, K., Kaufmann, M., Melvin, T.M., van der Plicht, J., Schießling, P., Thurner, A., 2009. A 9111 year long conifer tree-ring chronology for the European Alps - a base for environmental and climatic investigations. The Holocene 19, 909-920. 
Nussbaumer, S.U., Zumbühl, H.J., Steiner, D., 2007. Fluctuations of the Mer de Glace (Mont Blanc area, France) AD 1500-2050. Part I: The history of the Mer de Glace AD 1570-2003 according to pictorial and written documents. Zeitschrift für Gletscherkunde und Glazialgeologie 40(2005/2006), 5-140.

Nussbaumer, S.U., Nesje, A., Zumbühl, H.J., 2011a. Historical glacier fluctuations of Jostedalsbreen and Folgefonna (southern Norway) reassessed by new pictoral and written evidence. The Holocene 21, 455-471.

Nussbaumer, S.U., Steinhilber, F., Trachsel, M., Breitenmoser, P., Beer, J., Blass, A., Grosjean, M., Hafner, A., Holzhauser, H., Wanner, H., Zumbühl, H.J., 2011b. Alpine climate during the Holocene: a comparison between records of glaciers, lake sediments and solar activity. Journal of Quaternary Science 26(7), 703-713.

Nussbaumer, S.U., Zumbühl, H.J., 2012. The Little Ice Age history of the Glacier des Bossons, Mont Blanc massif, France, a new high-resolution glacier length curve based on historical documents. Climatic Change 111, 301-334, doi: 10.1007/s10584-011-0130-9.

Oerlemans, J., 1994. Quantifying global warming from the retreat of glaciers. Science 264, 243-245, doi:10.1126/science.264.5156.243.

Oerlemans, J., 2001. Glaciers and climate change, A. A. Balkema Publishers. 148 pp.

Oerlemans, J. 2012. Linear modeling of glacier fluctuations. Geografiska annaler. Series A, physical geography, 94 (2), 183-194). 
Osborn, G.D., Robinson, B.J., Luckman, B.H., 2001. Holocene and latest Pleistocene fluctuations of Stutfield Glacier, Canadian Rockies. Canadian Journal of Earth Sciences $38,1141-1155$.

Osborn, G., Menounos, B., Koch, J., Clague, J.J., Vallis, V., 2007. Multi-proxy record of Holocene glacial history of the Spearhead and Fitzsimmons ranges, southern British Columbia. Quaternary Science Reviews 26, 479-493.

Osborn, G., Menounos, B., Ryane, C., Riedel, J., Clague, J.J., Koch, J., Clark, D., Scott, K., Davis, P.T., 2012. Latest Pleistocene and Holocene glacier fluctuations on Mount Baker, Washington. Quaternary Science Reviews 49, 33-51.

Osborn, G., Haspel, R., Spooner, I., 2013. Late-Holocene fluctuations of the Bear River Glacier, northern Coast Ranges of British Columbia, Canada. The Holocene 23, 330-338.

Osborn, G., McCarthy, D., LaBrie, A., Burke, R., 2015. Lichenometric dating: Science or pseudo-science? Quaternary Research 83, 1-12.

Owen, L.A., Benn, D.I., 2005. Equilibrium-line altitudes of the Last Glacial Maximum for the Himalaya and Tibet: an assessment and evaluation of results. Quaternary International 138/139, 55-78.

Owen, L.A., Dortch, J.M., 2014. Quaternary glaciation of the Himalayan-Tibetan orogen. Quaternary Science Reviews 88, 14-54.

Owen, L.A., Caffee, M.W., Finkel, R.C., Seong, B.Y., 2008. Quaternary glaciations of 
the HimalayaneTibetan orogen. J. Quat. Sci. 23, 513-532.

PAGES 2ka consortium, 2013. Continental-Scale Temperature Variability during the Past Two Millennia. Nature Geoscience. 10.1038/NGEO1797.

Paterson, W.S.B., 1994. The physics of glaciers. Butterworth-Heinemann.

Patzelt, G., Aellen, M., 1990. Gletscher. In: Vischer, D., (Hrsg.): Schnee, Eis und Wasser der Alpen in einer wärmeren Atmosphäre. ETH-Zürich - VAW-Mitteilungen 108, 49-69.

Patzelt, G., 2013. Das Vorfeld des Vernagtferners und seine Umgebung. Begleitworte zur Karte 1:10.000. Zeitschrift für Gletscherkunde und Glazialgeologie 45/46 (2011/12), 2539.

Pitman, K.J., Smith, D.J., 2012. Tree-ring derived Little Ice Age temperature trends from the central British Columbia Coast Mountains, Canada. Quaternary Research 78, 417426.

Polissar, P.J., Abbott, M.B., Wolfe, A.P., Bezada, M., Rull, V., Bradley, R.S., 2006. Solar modulation of Little Ice Age climate in the tropical Andes. PNAS 103, 8937-8942.

Polyak, L., Murdmaa, I., Ivanova, E., 2004. A high-resolution, 800-year glaciomarine record from Russkaya Gavan', a Novaya Zemlya fjord, eastern Barents Sea. The Holocene 14(4), 628-634.

Porter, S.C., 1981. Recent glacier variations and volcanic eruptions: Nature 291, 139 142 (14 May 1981); doi:10.1038/291139a0. 
Porter, S.C., 1986. Pattern and forcing of Northern Hemisphere glacier variations during the last millennium. Quaternary Research 26, 1, 27-48.

Porter, S.C., Denton, G.H., 1967. Chronology of Neoglaciation in the North American cordillera. American Journal of Science 265, 177-210.

Porter, S.C., Santana, A., 2003. Rapid 20th century retreat of Ventisquero Marinelli in the Cordillera Darwin Icefield. Anales del Instituto de la Patagonia 31, 17-26.

Principato, S. M. 2008. Geomorphic evidence for Holocene glacial advances and sea level fluctuations on eastern Vestfirðir, northwest Iceland. Boreas, 37(1), 132-145.

Purdie, H., Anderson, B., Chinn, T., Owens, I., Mackintosh, A., Lawson, W. 2014. Franz Josef and Fox Glaciers, New Zealand: historic length records. Global and Planetary Change, 121, 41-52.

Putnam, A.E., Schaefer, J.M., Barrell, D.J.A., Vandergoes, M., Denton, G.H., Kaplan, M.R., Finkel, R.C., Schwartz, R., Goehring, B.M., Kelley, S.E., 2010. In situ cosmogenic 10Be production-rate calibration from the Southern Alps, New Zealand. Quaternary Geochronology 5, 392-409.

Putnam, A.E., Schaefer, J.M., Denton, G.H., Barrell, D.J.A., Andersen, B.G., Schwartz, R., Chinn, T.J.H., Doughty, A.M., 2012. Regional climate control of glaciers in New Zealand and Europe during the pre-industrial Holocene. Nature Geoscience 5, 627-630.

Rabatel, A., Jomelli, V., Francou, B., Naveau, P., Grancher, D. 2005. Dating Little Ice Age in the Tropics from the moraines of Charquini glaciers (Andes of Bolivia, $16^{\circ} \mathrm{S}$ ). CRAS, Géosciences, 337, 1311-1322. 
Rabatel, A., Francou, B., Jomelli, V., Naveau, P., Grancher, D. 2008. A chronology of the Little Ice Age in the tropical Andes of Bolivia $\left(16^{\circ} \mathrm{S}\right)$ based on moraine dating by lichenometry: implications for climate reconstruction. Quaternary Research, 70, 198-212.

Rabatel, A., Francou, B., Soruco, A., Gomez, J., Cáceres, B., Ceballos, J. L., Basantes, R., Vuille, M., Sicart, J.-E., Huggel, C., Scheel, M., Lejeune, Y., Arnaud, Y., Collet, M., Condom, T., Consoli, G., Favier, V., Jomelli, V., Galarraga, R., Ginot, P., Maisincho, L., Mendoza, J., M'en'egoz, M., Ramirez, E., Ribstein, P., Suarez, W., Villacis, M., and Wagnon, P. 2013 a. Current state of glaciers in the tropical Andes: a multi-century perspective on glacier evolution and climate change. The Cryosphere, 7(1), 81-102.

Rabatel A., Letréguilly A., Dedieu J.-P., Eckert N. 2013 b. Changes in glacier equilibrium-line altitude in the western Alps from 1984 to 2010: evaluation by remote sensing and modeling of the morpho-topographic and climate controls. The Cryosphere 7, $1455-1471$.

Rasmussen, L.A., Andreassen, L.M., Baumann, S., Conway, H., 2010. Little Ice Age precipitation in Jotunheimen, southern Norway. The Holocene 20, 1039-1045.

Reichert, B.K., Bengtsson, L., Oerlemans, J., 2001. Mid latitude forcing mechanisms for glacier mass balance investigated using general circulation models. Journal of Climate $14,3767-3784$.

Reimer, P. J., Bard, E., Bayliss, A., Beck, J.W., Blackwell, P.G., Ramsey, C.B., Buck, C.E., 2013. IntCal13 and Marine13 radiocarbon age calibration curves, 0-50,000 years cal BP. Radiocarbon 55(4), 1869-1887. 
Reusche, M., Winsor, K., Carlson, A.E., Marcott, S.A., Rood, D.H., Novak, A., Roof, S., Retelle, M., Werner, A., Caffee, M., Clark, P.U. 2014. 10Be surface exposure ages on the late-Pleistocene and Holocene history of Linnebreen on Svalbard. Quaternary Science Reviews 89, 5-12.

Reyes, A.V., Clague, J.J., 2004. Stratigraphic evidence for multiple Holocene advances of Lillooet Glacier, southern Coast mountains, British Columbia. Can. J. Earth Sci. 41, 903918.

Reyes, A., Wiles, G., Smith, D., Barclay, D., Allen, A., Jackson, S., Larocque, S., Lewis, D., Calkin, P.E., Claque, J. 2006. Expansion of Alpine glacier in Pacific North America in the first millenium A.D. Geology 34, 57-60.

Rignot, E., Rivera, A., Casassa, G. 2003. Contribution of the Patagonia icefields of South America to global sea level rise. Science 302, 434-437.

Rodbell, D.T. 1992. Lichenometric and radiocarbon dating of Holocene glaciation, Cordillera Blanca, Peru. The Holocene 2, 19-29.

Rodbell, D.T., Smith, J.A., Mark, B.G., 2009. Glaciation in the Andes during the Lateglacial and Holocene. Quaternary Science Reviews 28(21-22), 2165-2212.

Røthe, T. O., Bakke, J., Vasskog, K., Gjerde, M., D'Andrea, W. J., \& Bradley, R. S. (2015). Arctic Holocene glacier fluctuations reconstructed from lake sediments at Mitrahalvøya, Spitsbergen. Quaternary Science Reviews, 109, 111-125. 
Rosqvist, G., Jonsson, C., Yam, R., Karlén, W., Shemesh, A., 2004. Diatom oxygen isotopes in proglacial lake sediments from northern Sweden: a 5000 year record of atmospheric circulation. Quaternary Science Reviews 23, 851-859.

Røthe, T.O., Bakke, J., Vasskog, K., Gjerde, M., D’Andrea, W.J., Bradley, R.S. 2015. Artic Holocene glacier fluctuations reconstructed from lake sediments at Mitrahalvøya, Spitsbergen. Quaternary Science Reviews 109, 111-125.

Röthlisberger, F., 1986. 10,000 Jahre Gletschergeschichte der Erde. Verlag Sauerländer, Aarau.

Röthlisberger, F. and Geyh, M. 1985. Glacier Variations in Himalayas and Karakoram. Zeitschrift für Gletscherkunde und Glazialgeologie 21, 237-249.

Ruiz, L., Masiokas, M.H., Villalba, R. 2012. Fluctuations of Glaciar Esperanza Norte in the north Patagonian Andes of Argentina during the past 400 yr. Climate of the Past 8, 1079-1090.

Samolczyk, M.A., Osborn, G., Menounos, B., Clague, J.J., Davis, P.T., Riedel, J., Koch, J. 2010. A comparison of glacier fluctuations on Mount Rainier to regional glacial histories. Abstracts, GeoCanada 2010, Calgary, Alberta.

Sato, T., Shiraiwa, T., Greve, R., Seddik, H., Edelmann, E., Zwinger, T., 2013. Accumulation reconstruction and water isotope analysis for 1735-1997 of an ice core from the Ushkovsky volcano, Kamchatka, and their relationships to North Pacific climate records. Clim. Past Discuss. 9, 2153-2181. 
Schaefer, J.M., Denton, G.H., Kaplan, M., Putnam, A., Finkel, R.C., Barrell, D.J.A., Andersen, B.G., Schwartz, R., Mackintosh, A., Chinn, T., Schlüchter, C., 2009. Highfrequency Holocene glacier fluctuations in New Zealand differ from the Northern signature. Science 324, 622-625.

Schimmelpfennig, I., Schaefer, J.M., Akçar, N., Ivy-Ochs, S., Finkel, R.C., Schlüchter, C., 2012. Holocene glacier culminations in the Western Alps and their hemispheric relevance. Geology 40, 891-894.

Schimmelpfennig, I., Schaefer, J.M., Akçar, N., Koffman, T., Ivy-Ochs, S., Schwartz, R., Finkel, R.C., Zimmerman, S., Schlüchter, C.A., 2014. Chronology of Holocene and Little Ice Age glacier culminations of the Steingletscher, Central Alps, Switzerland, based on high-sensitivity beryllium-10 moraine dating. Earth Planet. Sci. Lett. 393, 220-230.

Schöner, W., Böhm, R., 2007. A statistical mass-balance model for reconstruction of LIA ice mass for glaciers in the European Alps. Annals of Glaciology 46, 161-169.

Schomacker, A., Krüger, J., Larsen, G., 2003. An extensive late Holocene glacier advance of Kötlujökull, central south Iceland. Quaternary Science Reviews 22, 1427-1434.

Seierstad, J., Nesje, A., Dahl, S.O., Simonsen, J., 2002. Holocene glacier fluctuations of Grovabreen and Holocene snow-avalanche activity reconstructed from lake sediments in Grøningstølsvatnet, western Norway. The Holocene 12, 211-222. 
Sepulveda, J., Pantoja, S., Hughen, K.A., Bertrand, S., Figueroa, D., Leon, T., Drenzek, N.J., Lange, C., 2009. Late Holocene sea-surface temperature and precipitation variability in northern Patagonia, Chile (Jacaf Fjord, 44_S). Quaternary Research 72, 400-409.

Serebryanny, L.R., Golodkovskaya, N.A., Orlov, E.V., Maliasova, E.S., 1984. Glacier variations and moraine accumulation processes in the Central Caucasus (Kolebaniya lednikov I protsessi morenonakopleniya na Kavkaze). Nauka, Moscow (In Russian).

Shakesby, R.A., Smith, J.G., Matthews, J.A., Winkler, S., Quentin Dresser, P., Bakke, J., Dahl, S.O., Lie, Ø., Nesje, A., 2007. Reconstruction of Holocene glacier history from distal sources: glaciofluvial stream-bank mires and a glaciolacustrine sediment core near Sota Sæter, Breheimen, southern Norway. The Holocene 17, 729-745.

Scherler et al., 2012 Scherler, D., Bookhagen, B., \& Strecker, M. R. 2011. Spatially variable response of Himalayan glaciers to climate change affected by debris cover. Nature geoscience, 4(3), 156-159.

Sigl, M., McConnell, J.R., Layman, L., Maselli, O., McGwire, K., Pasteris, D., DahlJensen, D., Steffensen, P., Vinther, B., Edwards, R., Mulvaney, R., Kipfstuhl, S., 2013. A new bipolar ice core record of volcanism from WAIS Divide and NEEM and implications for climate forcing of the last 2000 years. Journal of Geophysical Research: Atmospheres 118, 1151-1169, doi:10.1029/2012JD018603.

Sigl, M., McConnell1, J.R., Toohey, M., Curran, M., Das, S.B., Edwards, R., Isaksson, E., Kawamura, K., Kipfstuhl, S., Krüger, K., Layman, L., Maselli, O., Motizuki, Y., Motoyam, H., Pasteris, D., Severi, M., 2014. Insights from Antarctica on volcanic forcing during the Common Era. Nature Climate Change DOI: 10.1038/NCLIMATE2293. 
Sigl, M., Winstrup, M., McConnell, J. R., Welten, K. C., Plunkett, G., Ludlow, F., BuËntgen, U., Caffee, M., Chellman, N., Dahl-Jensen, D., Fischer, H., Kipfstuhl, S., Kostick, C., Maselli, O. J., Mekhaldi, F., Mulvaney, R., Muscheler, R., Pasteris D. R., Pilcher, J. R., Salzer, M., Schü̈pbach, S., Steffensen, J. P., Vinther, B. M., Fischer, H., 2015. Timing and climate forcing of volcanic eruptions for the past 2,500 years. Nature. doi:10.1038/nature14565.

Simonneau, A., Chapron, E., Garçon, M., Winiarski, T., Graz, Y., Chauvel, C., Debret, M., Motelica- Heino, M., Desmet, M., Di Giovanni, C., 2014. Tracking Holocene glacial and high-altitude alpine environments fluctuations from minerogenic and organic markers in proglacial lake sediments (Lake Blanc Huez, Western French Alps). Quaternary Science Reviews 89, 27-43.

Six, D., Reynaud, L., Letréguilly, A., 2001. Bilans de masse des glaciers alpins et scandinaves, leurs relations avec l'oscillation du climat de l'Atlantique nord. Earth and Planetary Sciences 333, 693-698.

Six, D., Vincent, C., 2014. Sensitivity of mass balance and equilibrium-line altitude to climate change in the French Alps Laboratoire. Journal of Glaciology 60(223), doi: 10.3189/2014JoG14J014 867.

Snyder, J. A., Werner, A., \& Miller, G. H. 2000. Holocene cirque glacier activity in western Spitsbergen, Svalbard: sediment records from proglacial Linnévatnet. The Holocene, 10(5), 555-563.

Solomina, O.N., 1999. Mountain glaciation of Northern Eurasia in Holocene. Moscow, Nauchny Mir. 264 PP. (in Russian). 
Solomina, O., Calkin, P.E., 2003. Lichenometry as applied to moraines in Alaska, U.S.A., and Kamchatka, Russia. Arct. Antarct. Alp. Res. 35, 129-143.

Solomina, O.N., Muraviev, Y.D., Bazanova, L.I., 1995. Little Ice Age glaciers in Kamchatka. Ann. Glaciol. 216, 240-244.

Solomina, O., Wiles, G., Shiraiwa, T., D’Arrigo, R., 2007. Multiproxy records of climate variability for Kamchatka for the past 400 years. Clim. Past 3, 119-128.

Solomina, O., Bradley, R.S., Hodgson, D.A., Ivy-Ochs, S., Jomelli, V., Mackintosh, A.N., Nesje, A., Owen, L.A., Wanner, H., Wiles, G.C., Young, N.E., 2015. Holocene glacier fluctuations. Quaternary Science 111, 9-34.

Solomina, 0., Bushueva, I., Dolgova, E., Jomelli, V., Alexandrin, M., Mikhalenko, V., \& Matskovsky, V. Glacier variations in the Northern Caucasus compared to climatic reconstructions over the past millennium. Global and Planetary Change, 140, 28-58.

Stansell, N. D., Rodbell, D. T., Abbott, M. B., \& Mark, B. G. 2013. Proglacial lake sediment records of Holocene climate change in the western Cordillera of Peru. Quaternary Science Reviews, 70, 1-14.

Stansell, N. D., Polissar, P. J., Abbott, M. B., Bezada, M., Steinman, B. A., \& Braun, C. 2014. Proglacial lake sediment records reveal Holocene climate changes in the Venezuelan Andes. Quaternary Science Reviews, 89, 44-55.

Steinman, B. A., Abbott, M. B., Mann, M. E., Stansell, N. D., \& Finney, B. P. 2012. 1,500 year quantitative reconstruction of winter precipitation in the Pacific Northwest. Proceedings of the National Academy of Sciences, 109(29), 11619-11623.

Steiner, D., Pauling, A., Nussbaumer, S.U., Nesje, A., Luterbacher, J., Wanner, H., Zumbühl, H.J., 2008. Sensitivity of European glacierst o precipitation and temperature two case studies. Climatic Change, 90, 413-441. 
Steinhilber, F., Beer, J., Fröhlich, C., 2009. Total solar irradiance during the Holocene. Geophys. Res. Lett. 36, L19704, doi:10.1029/2009GL040142.

Stone, J. O. 2000. Air pressure and cosmogenic isotope production. J. Geophys. Res. 105, $23753-23759$.

Stotter, J., Wastl, M., Caseldine, C., Haberle, T., 1999. Holocene paleoclimatic reconstructions in Northern Iceland: Approaches and results. Quaternary Science Reviews 18, 457-474.

Strelin, J., Iturraspe, R., 2007. Recent evolution and mass balance of Cordón Martial glaciers, Cordillera Fueguina Oriental. Global and Planetary Change 59, 17-26.

Strelin, J., Casassa, G., Rosqvist, G., Holmlund, P., 2008. Holocene glaciations in the Ema glacier valley, Monte Sarmiento massif, Tierra del Fuego. Palaeogeography, Palaeoclimatology, Palaeoecology 260, 299-314.

Strelin, J.A., Kaplan, M.R., Vandergoes, M.J., Denton, G.H., Schaefer, J.M., 2014. Holocene glacier history of the Lago Argentino basin, Southern Patagonian Icefield. Quaternary Science Reviews 101, 124-145.

Stroeven, A.P., Heyman, J., Fabel, D., Björck, S., Caffee, M.W., Fredin, O., Harbor, J.M., 2015. A new Scandinavian reference 10Be production rate. Quaternary Geochronology $29,104-115$. 
Stroup, J.S, Kelly, M.A., Lowell, T.V., Applegate, P.J., Howley, J.A., 2014. Late Holocene fluctuations of Qori Kalis outlet glacier, Quelccaya Ice Cap, Peruvian Andes. Geology doi:10.1130/G35245.11.

Stroup, J. S., Kelly, M. A., Lowell, T. V., Applegate, P. J., \& Howley, J. A. (2015). Late Holocene fluctuations of Qori Kalis outlet glacier, Quelccaya Ice Cap, Peruvian Andes. Erratum. Geology, 43(12), 1113-1113.

Stuiver, M., Reimer, P. J., Reimer, R.W., 2005. CALIB 5.0. [WWW program and documentation].

Svendsen, J.I., Mangerud, J., 1997. Holocene glacial and climatic variations on Svalbard, Svalbard. The Holocene 7, 45-57.

Szczuciński, W., Zajączkowski, M., Scholten, J., 2009. Sediment accumulation rates in subpolar fjords-Impact of post-Little Ice Age glaciers retreat, Billefjorden, Svalbard. Estuarine, Coastal and Shelf Science 85, 345-356.

Thompson, L.G., Mosley-Thompson, E., Davis, M.E., Zagorodnov, V.S., Howat, I.M., Mikhalenko, V.N., Lin, P.N., 2013. Annually resolved ice core records of tropical climate variability over the past $\sim 1800$ year. Science $340,945-950$, doi:10.1126/science.1234210.

Trachsel, M., Nesje, A., 2015. Modelling annual mass balances of eight Scandinavian glaciers using statistical models. The Cryosphere 9, 1401-1414, doi:10.5194/tc-9-14012015.

Trouet, V., Diaz, H.F., Wahl, E.R., Viau, A.E., Graham, R., Graham, N., Cook, E.R., 2013. A 1500-year reconstruction of annual mean temperature for temperate North 
America on decadal-to-multidecadal time scales. Environmental Research Letters 8, 024008.

Tyson, P. D., Sturman, A. P., Fitzharris, B. B., Mason, S. J., and Owens, I. F. (1997). Circulation changes and teleconnections between glacial advances on the west coast of New Zealand and extended spells of drought years in South Africa. International Journal of Climatology, 17(14), 1499-1512.

Vasskog, K., Paasche, Ø., Nesje, A., Boyle, J.F., Birks, H.J.B., 2012. A new approach for reconstructing glacier variability based on lake sediments recording input from more than one glacier. Quaternary Research 77, 192-204.

Vaughan, D.G., Comiso, J.C., Allison, I., Carrasco, J., Kaser, G., Kwok, R., Mote, P., Murray, T., Paul, F., Ren, J., Rignot, E., Solomina, O., Steffen, K., Zhang, T., 2013. Observations: Cryosphere. In: Climate Change 2013: The Physical Science Basis. Contribution of Working Group I to the Fifth Assessment Report of the Intergovernmental Panel on Climate Change [Stocker, T.F., D. Qin, G.-K. Plattner, M. Tignor, S.K. Allen, J. Boschung, A. Nauels, Y. Xia, V. Bex and P.M. Midgley (eds.)]. Cambridge University Press, Cambridge, United Kingdom and New York, NY, USA.

Viau, A.E., Ladd, M., Gajewksi, K., 2012. The climate of North America during the past 2000 years reconstructed from pollen data. Global and Planetary Change 84-85, 75-83.

Villalba, R., Leiva, J.C., Rubulis, S., Suarez, J.A., 1990. Climate, tree rings and glacier fluctuations in the Rio Frias Valley, Rio Negro, Argentina. Arctic and Alpine Research $22(3), 215-232$. 
Villalba, R., Lara, A., Boninsegna, J.A., Masiokas, M., Delgado, S., Aravena, J.C., Roig, F.A., Schmelter, A., Wolodarsky, A., Ripalta, A., 2003. Large-scale temperature changes across the southern Andes: 20th-century variations in the context of the past 400 years. Climatic Change 59, 177-232.

Vincent, C., Le Meur, E., Six, D., Funk, M., 2005. Solving the paradox of the end of the Little Ice Age in the Alps. References GRL 32, L09706, doi:10.1029/2005GL022552, 2005.

Vinogradov, V.N., Muravyev, Y.D., Ovsyannikov, A.A., 1985. Influence of eruption of Plosky Tolbachik volcano in 1975-76 on snow cover and glaciers. Voprosy Geographii Kamchatki 9, 95-102 (In Russian).

Wang, Y., Cheng, H., Edwards, R.L., He, Y., Kong, X., An, Z., Wu, J., Kelly, M.J., Dykoski, C.A., Li, X., 2005. The Holocene Asian monsoon, links to solar changes and North Atlantic climate. Science 308, 854-857.

Wanner, H., Holzhauser, H., Pfister, C., \& Zumbühl, H. 2000. Interannual to century scale climate variability in the European Alps (Die Klimavariabilität im europäischen Alpenraum auf der Zeitskala von Jahren bis Jahrhunderten). Erdkunde, 62-69.

Wanner, H., Beer, J., Bütikofer, J., Crowley, T.J., Cubasch, U., Flückiger, J., Goosse, H., Grosjean, M., Joos, F., Kaplan, J.O., Küttel, M., Müller, S., Prentice, I.C., Solomina, O., Stocker, T.F., Tarasov, P., Wagner, M., Widmann, M., 2008. Mid- to late Holocene climate change: an overview. Quaternary Sciience Reviews 27, 1791-1828. 
Wanner, H., Solomina, O., Grosjean, M., Ritz, S. P., \& Jetel, M. 2011. Structure and origin of Holocene cold events. Quaternary Science Reviews, 30(21), 3109-3123.

Wardle, P., 1973. Variations in glaciers of Westland National Park and the Hooker Range, New Zealand. New Zealand Journal of Botany, 11, 349-388.

Watson, E., \& Luckman, B. H. 2004. Tree-ring-based mass-balance estimates for the past 300 years at Peyto Glacier, Alberta, Canada. Quaternary Research, 62(1), 9-18.

Warren, C., Aniya, M., 1999. The calving glaciers of southern South America. Global and Planetary Change 22, 59-77.

Weidick, A. 1958. Frontal variations at Upernaviks Isstrøm in the last 100 years. Fr. Bagges Kgl. Hofbogtrykkeri.

Weidick, A., 1968. Observations on some Holocene glacier fluctuations in west Greenland. Meddelelser om Grønland 165, 1-202.

Weidick, A., 2009. Johan Dahl Land, south Greenland: the end of a 20th century glacier expansion. Polar Record 45, 337-350.

Weidick, A., Bennike, O., Citterio, M., Nørgaard-Pedersen, N., 2012. Neoglacial and historical glacier changes around Kangersuneq fjord in southern West Greenland. Geological Survey of Denmark and Greenland 27, 1-68.

Werner, A., 1993. Holocene moraine chronology, Spitsbergen, Svalbard: lichenometric evidence for multiple Neoglacial advances in the Arctic. The Holocene 3, 128-137. 
WGMS, 2008: Global Glacier Changes: Facts and Figures. [Zemp, M, I. Roer, A. Kääb, M. Hoelzle, F. Paul, W. G. Haeberli (eds.)] UNEP and World Glacier Monitoring Service, Zurich, Switzerland, 88 pp.

Wiles, G.C., Calkin, P.E., and Post, A. 1995. Glacial fluctuations in the Kenai Fjords, Alaska, U.S.A.: an evaluation of controls on iceberg-calving glaciers. Arctic and Alpine Research 27, 234-245.

Wiles, G.C., Jacoby, G.C., Davi, N.K., McAllister, R.P., 2002. Late Holocene glacier fluctuations in the Wrangell Mountains, Alaska. Geological Society of America Bulletin 114, 896-908.

Wiles, G.C., D’Arrigo, R.D., Villalba, R., Calkin, P.E., Barclay, D.J., 2004. Century-scale solar variability and Alaskan temperature changes over the past millennium. Geophysical Research Letters 31, 35-36.

Wiles, G.C., Barclay, D.J., Calkin, P.E., Lowell, T.V., 2008. Century to Millennial-Scale Temperate Variations for the Last Two Thousand Years Inferred from Glacial Geologic Records of Southern Alaska. Global and Planetary Change 57, doi:10.1016/j.gloplacha.2006.07.036.

Wiles, G.C., Lawson, D.L., Lyon, E., Wiesenberg, N., 2011. Tree-ring dates on two preLittle Ice Age advances in Glacier Bay National Park and Preserve. Quaternary Research 76(2), 190-195, doi:10.1016/j.yqres.2011.05.005. 
Wiles, G.C., D’Arrigo, R.D., Barclay, D., Wilson, R.S., Jarvis, S.K., Vargo, L., Frank, D., 2014. Surface air temperature variability reconstructed with tree rings for the Gulf of Alaska over the past 1200 years. The Holocene 24, 198-208.

Winchester, V., Harrison, S., 1996. Recent oscillations of the San Quintín and San Rafael glaciers, Patagonian Chile. Geografiska Annaler 78A, 35-49.

Winchester, V., Harrison S., Warren, C.R., 2001. Recent retreat Glaciar Nef, Chilean Patagonia, dated by lichenometry and dendrochronology. Arctic, Antarctic and Alpine Research 33(3), 266-273.

Winkler, S., Matthews, J.A., 2010. Glacier chronologies: Are 'high-resolution' global and inter-hemispheric comparisons possible? The Holocene 20(7), 1137-1147. DOI: 10.1177/0959683610369511.

Winkler, S., Matthews, J.A., Shakesby, R.A., Dresser, P.Q., 2003. Glacier variations in Breheimen, southern Norway: dating Little Ice Age moraine sequences at seven lowaltitude glaciers. Journal of Quaternary Science 18, 395-413.

Winsor, K., Carlson, A. E., Rood, D.H., 2014. 10Be dating of the Narsarsuaq moraine in southernmost Greenland: evidence for a late-Holocene ice advance exceeding the Little Ice Age maximum. Quaternary Science Reviews 98, 135-143.

Wittmeier, H.E., 2014. Late Glacial and Holocene glacier activity in Arctic Norway. Reconstruction of glacier fluctuations using surface exposure dating of moraines and 
multi-proxy analysis of sediments deposited in distal glacier-fed lakes. PhD Thesis University of Bergen, Norway.

Wittmeier, H.E., Bakke, J., Vasskog, K., Trachsel, M., 2015. Reconstructing Holocene glacier activity at Langfjordjøkelen, Arctic Norway, using multi-proxy fingerprinting of distal glacier-fed lake sediments. Quaternary Science Reviews 114, 78-99.

Xu, P., Zhu, H., Shao, X., Yin, Z., 2012. Tree ring-dated fluctuation history of Midui glacier since the little ice age in the southeastern Tibetan plateau. Science China Earth Science 55, 521-529.

Xu, X., Yi, C., 2014. Little Ice Age on the Tibetan Plateau and its bordering mountains: Evidence from moraine chronologies. Global and Planetary Change 116, 41-53.

Yadav, R.R., Braeuning, A., Singh, J., 2011. Tree ring inferred summer temperature variations over the last millennium in western Himalaya, India. Climate Dynamics 36, $1545-1554$.

Yamagata, K., Sone, T., Sawagaki, T., Otsuki, Y., Muravyev, Y.D., 2000. Holocene glacial history of the Kamchatka Peninsula. In: Wakatsuchi, M., Hara, T. (Eds.), Proceedings of Int. Symp. On Atmosphere-Ocean-Cryosphere Interaction in the Sea of Okhotsk and the Surrounding Environment. Inst. Of Low Temperature, Hokkaido University, Sapporo, Japan, 164-165.

Yamagata, K., Sone, T., Sawagaki, T., Muravyev, Y.D., 2002. Holocene fluctuations of the Bilchenok Glacier, Kamchatka Peninsula. J. Geogr. 111, 509-518. 
Yamaguchi, S., Naruse, R., Shiraiwa, T., 2008. Climate reconstruction since the Little Ice Age by modelling Koryto glacier, Kamchatka Peninsula, Russia. J. Glaciol. 54, 125-130.

Yang, B., Bräuning, A., and Yafeng, S. 2003. Late Holocene temperature fluctuations on the Tibetan Plateau. Quaternary Science Reviews 22, 2335-2344.

Yang, B., Bräuning, A., Dong, Z., Zhang, Z., Keqing, J. 2008. Late Holocene monsoonal temperate glacier fluctuations on the Tibetan Plateau. Global and Planetary Change 60, 126-140.

Young, N.E., Briner, J.P. 2015. Holocene evolution of the western Greenland Ice Sheet: Assessing geophysical ice-sheet models with geological reconstructions of ice-margin change. Quaternary Science Reviews 114, 1-17.

Young, N.E., Briner, J.P., Kaufman, D.S. 2009. Late Pleistocene and Holocene glaciation of the Fish Lake valley, northeastern Alaska Range, Alaska. Journal of Quaternary Science 24, 677-689, doi:10:1002/jqs.1279.

Young, N.E., Briner, J.P., Stewart, H.A.M., Axford, Y., Csatho, B., Rood, D.H., Finkel, R.C. 2011. Response of Jakobshavn Isbrae, Greenland, to Holocene climate change. Geology 39, 131-134.

Young, N.E., Schaefer, J.M., Briner, J.P., Goehring, B.M., 2013. A 10Be production-rate calibration for the Arctic. Journal of Quaternary Science 28, 515-526. 
Young, N.E., Schweinsberg, A.D., Briner, J.P., Schaefer J.M., 2015. Glacier maxima in Baffin Bay during the Medieval Warm Period coeval with Norse settlement. Sci. Adv. 2015(1), 1500806.

Zander, P.D., Kaufman, D.S., Kuehn, S.C., Wallace, K.L., Anderson, R.S., 2013. Early and late Holocene glacial fluctuations and tephrostratigraphy, Cabin Lake, Alaska. Journal of Quaternary Science 28(8), 761-771, doi:10.1002/jqs.2671.

Zech, W., Glaser, B., Ni, A., Petrov, M., Lemzin, I., 2000. Soil as indicators of the Pleistocene and Holocene landscape history: Alay Range (Khyrgstan). Quaternary International 65/66, 161-170.

Zeeberg, J., Forman, S.L., 2001. Changes in glacier extent on north Novaya Zemlya in the twentieth century. The Holocene 11(2), 161-175.

Zeeberg, J., Forman, S. L., \& Polyak, L. 2003. Glacier extent in a Novaya Zemlya fjord during the" Little Ice Age" inferred from glaciomarine sediment records. Polar research, 22(2), 385-394.

Zemp, M., Hoelzle, M., Haeberli, W., 2007. Distributed modelling of regional climatic equilibrium line altitude of glaciers in the European Alps. Global and Planetary Change $56,83-100$.

Zemp, M., Paul, F., Hoelzle, M., Haeberli, W., 2008. Glacier fluctuations in the European Alps 1850-2000: an overview and spatio-temporal analysis of available data. In: Orlove, B., Wiegandt, E., Luckman, B.H. (eds.): Darkening Peaks - Glacial Retreat, Science and Society. University of California Press, 152-167. 
Zhang, Q. B., \& Hebda, R. J. 2005. Abrupt climate change and variability in the past four millennia of the southern Vancouver Island, Canada. Geophysical Research Letters, 32(16).

Zhou, S., Chen, F., Pan, B., Cao, J., Li, J., Derbyshire, E., 1991. Environmental change during the Holocene in western China on a millennial timescale. The Holocene 1-2, 151156, doi: $10.1177 / 095968369100100207$

Zhu, H., Xu, P., Shao, X., Luo, H., 2013. Little Ice Age glacier fluctuations reconstructed for the southeastern Tibetan Plateau using tree rings. Quaternary International 283, 134138.

Zolitschka, B., 2007. Varved lake sediments. Encyclopedia of quaternary science. Elsevier, Amsterdam, 3105-3114.

Zolitschka, B., Francus, P., Ojala, A.E.K., Schimmelmann, A., 2015. Varves in lake sediments: a review. Quaternary Science Reviews 117, 1-41.

Zumbühl, H.J., Messerli, B., Pfister, C., 1983. Die Kleine Eiszeit. Gletschergeschichte im Spiegel der Kunst. Katalog zur Sonderausstellung des Schweizerischen Alpinen Museums Bern und des Gletschergarten-Museums Luzern. 9.6.-14.8.1983 Luzern, 24.8.16.10.1983 Bern.

Zumbühl, H.J., Steiner, D., Nussbaumer, S.U., 2008. 19th century glacier representations and fluctuations in the central and western European Alps: An interdisciplinary approach. Global and Planetary Change 60, 42- 57.

Quaternary Science Reviews v. 7, issue 2, 1988 and v. 28, 2009 
Holocene and Latest Pleistocene Alpine Glacier Fluctuations: A Global Perspective. 2009. Quaternary Science Reviews, 28(21).

\section{Figure captions}

Figure 1. Spatial distribution of time series used in this paper.

1. Alaska; 2. Western Canada and US; 3. Arctic Canada; 4. Greenland; 5. Iceland; 6. Svalbard; 7. Scandinavia; 8. Russian Arctic; 9. North Asia; 10. Central Europe; 11. Caucasus and Middle East; 12. Central Asia (semi-arid); 13. Central Asia (monsoon); 14. Low Latitudes; 15. Desert-Central Andes of Chile and Argentina. 16. South of South America (North Patagonian Andes; North Patagonian Icefield, South Patagonian Icefield and adjacent glaciers, Magellanes region - Tierra del Fuego) 17. New Zealand. For individual time series description see Table 1 in SM.

Figure 2. Regional glacier variations and regional climate proxies.

Alaska. Summer temperature (July-August) reconstruction inferred from maximum latewood density of tree rings for the Firth River, northwestern Alaska (Anchukaitis et al., 2013) (A), February-August temperature reconstruction for southern coastal Alaska based on ring-widths (Wiles et al., 2014) (B), Glacier Expansion Index (GEI), Wiles et al., 2004) derived from glacial histories from the Arctic Brooks Range to the southern 
coastal regions across Alaska. The record is based on ages of moraines and intervals of ice expansion dated with radiocarbon, lichenometry and tree-rings $(\mathbf{C})$. General intervals of ice advance for the past $2 \mathrm{ka}$ summarized in the text $(\mathbf{D})$. Vertical stripes - intervals of glacier advances corresponding to coolings.

Western Canada. Reconstructed relative glacier extent in western North America (bold black line) plotted with a reconstruction of 30 year averages of annual mean temperature deviations from a 1904 to 1980 average for temperate North America $\left(30^{\circ}-55^{\circ} \mathrm{N}, 75^{\circ}-\right.$ $130 \circ \mathrm{W})$ based on pollen data (blue line) and on tree-ring data (red line). Light (medium) blue zones indicate 2SE (1SE) uncertainty estimations associated with each 30 year value. Also plotted is the comparably smoothed instrumental temperature values up to 1980 (fine black line). All data other than glacier extent is modified from Trouet et al. (2013).

Arctic Canada. Cumulative probability density function of 118 calibrated radiocarbon dates on in situ tundra plants collected within $1 \mathrm{~m}$ of the margin of retreating ice caps across Baffin Island, Arctic Canada. Clusters of dates define periods when colder summers lowered snowline, entombing living plants, and remaining across the site until shortly before the year of their collection (CE 2005 to 2010). The dates record periods of glacier advance. Data from Miller et al. (2012, 2013).

Iceland. Temperature anomaly based on composite proxy records from Haukadaslsvatn and Hvitarvatn (A). Hvitarvatn varve thickness and glacial advances in Iceland (triangles) (Larsen et al., 2011; Geirsdóttir et al., 2013) (B). 
Scandinavia. Composite record of Scandinavian glacier variations during the past two millennia based on continuous records from glacier-fed lakes (A). Records from Northern Folgefonna (Bakke et al., 2005b), Grovabreen (Seierstad et al., 2002), Jostedalsbreen (Nesje et al., 1991, 2001; Vasskog et al., 2012), Spørteggbreen (Nesje et al., 2006), Breheimen (Shakesby et al., 2007), Jotunheimen (Matthews et al., 2000; Matthews and Dresser, 2008), Austre Okstindbreen (Bakke et al., 2010), Lyngen (Bakke et al., 2005a), Langfjordjøkelen (Wittmeier, 2014), and Northern Sweden (Rosqvist et al., 2004). For details, see original publications. Summer temperature reconstruction based on the Tornetra"sk pine ring width chronology (Grudd et al., 2002) (B).

Russian Arctic. Glacier advances in Franz Josef Land (Lubinski et al., 1999) (A). Ice core records from Windy Dome, Garham Bell (Henderson, 2002): accumulation (B), melt features - summer temperature proxies $(\mathbf{C})$. Glacier fluctuations in Novaya Zemlya (Forman et al., 1999; Zeeberg and Forman, 2001; Murdmaa et al., 2004) (D), June-July temperature tree-ring based reconstruction in N-W SIbiria (Briffa et al., 2013) (E). Orange vertical stripes - glacier advances corresponding to coolings, gray stripe advance corresponding to high temperature and high accumulation.

Altay. Glacier fluctuations in Altay Mountains (Nazarov et al., 2012) (A), summer temperature sensitive tree-ring chronology from Mongun-Tayga Mountains (Myglan et al., 2012a, b) (B). Orange vertical stripes - periods of glacier advances corresponding to summer coolings, gray stripe - glacier retreat and a warming of the first half of the first millennium CE. 
Alps. Glacier length changes in the Alps. Great Aletsch Glacier (Holzhauser et al., 2005) (A), Mer de Glace (Le Roy et al., 2015) (B), Tree-ring width chronology in the Alps (sensitive to summer temperature), red curve - 30-years running means, black curve - 50 years averages (Nicolussi et al., 2009) (C). Vertical orange stripes outline the glacier advances corresponding to the coolings. The gray stripe - glacier retreat and warming during the MCA.

Tibet (temperate monsoon glaciers). Dendrochronological dates of moraines in Tibet (Bräuning, 2006; Zhu et al., 2013; Xu et al., 2012; Hochreuther et al., 2015; Loibl et al., 2015) in comparison with decadal summer temperature reconstructions (summer temperature anomalies with respect to long-term average (1000-2005 CE) (Wang et al., 2015) (A). Relative glacier extent based on ${ }^{14} \mathrm{C}$ dating (Yang et al., 2008) (B), composite temperature records in Tibetan Plateau (standardized deviations with respect to the last two millennia) (Yang et al., 2003) $(\mathbf{C})$, speleothem $\delta 180$ record in Dongge Cave reflecting the south Asian monsoon variability (Wang et al., 2005) (D).

Southern South America. Paleoclimatic proxies and number of glacier advances in South America. SAM-like centennial changes in southern South American climate derived from a stratigraphic record of non-arboreal pollen, Lago Cipreses $\left(51^{\circ} \mathrm{S}\right)$ (Moreno et al. 2014). The persistently positive (negative) phases of SAM are associated with warm/dry (cold/wet) climate conditions in southern South America (A). Number of glacial advances in subregions of South America (B). Darker cells indicate synchronous advances from different sites for the 100-years periods, lighter cells indicate isolated or less synchronous events. Each cell indicates the number of glacier advances identified for 
each 100-years period (Röthlisberger, 1986; Aniya, 1995; Strelin et al., 2008, 2014; Masiokas et al., 2009; Aniya and Skvarca, 2013). 1 - Desert central Andes of Chile and Argentina, 2 - North Patagonian Andes, 3 - North Patagonian Icefield, 4 - South Patagonian Icefield and adjacent glaciers; 5 - Magallanes region - Tiera del Fuego.

New Zealand. Summer temperature reconstruction (Cook et al., 2002) (A) and glacier variations in New Zealand (from Schaefer et al., 2009; Putnam et al., 2012) (B). Vertical stripes indicate most prominent coolings corresponding to glacier advances.

Figure 3. Glacial extent: yellow - glacier(s) smaller than now (end of $20^{\text {th }}$-early $21^{\text {st }}$ centuries); pale yellow - glacier(s) smaller than maximum extent, but size is generally not well known (included here only if this status is clearly indicated in the original publications, mostly based on the ages of wood incorporated into till or overrun by glaciers); light green - glaciers present in the watersheds (only for lake sediments records); light blue - glacier(s) advancing or expanded; dark blue - glacier(s) close to or at their maximum extent of the past $2 \mathrm{ka}$. Although a few glaciers experienced smallscale, intermittent advances during recent decades they were too minor to represent on this summary diagram. The empty cells indicate the absence of information on the glacier status. The descriptions of all series are listed in SM Table 1. The sequence of the series corresponds to the sequence of the records in the SM Table 1. Temperature reconstructions gridded at 50 years (50-years mean) (PAGES 2 ka, 2013).

Figure 4. Selected time series for glacier size spanning the past 2 millennia. 1. Spitsbergen. Reconstructed ELA (5 pt. running mean) from Karlbreen (Røthe et al., 2015). 2. Alaska. Time-distance diagram for Sheridan Glacier. Horizontal green lines 
show intervals of forest growth on forefields (Barclay et al., 2013). 3. Western Canada. Compilation of glacier extents (Koch, this study). Iceland. Sediment flux into glacial lake Hvítárvatn - proxy for glacial activity (Larsen et al., 2013). Southern Scandinavia. Reconstructed Equilibrium Line Altitude (ELA) (compilation from Nesje et al., 2001, Bakke et al., 2005; Vasskog et al., 2012). The Alps. Fluctuations of Great Aletsch and Lower Grindelwald Glacier (Holzhauser et al., 2005), and Mer de Glace Glacier (Le Roy et al., 2015). 7. Altay, Southern Sibiria. Glacier fluctuations based on $14 \mathrm{C}$ and tree-ring dating of wood buried by glacial deposits (Nazarov et al., 2012, modified). Glacier fluctuations in Western Tibet. Compilation from tree-ring, OSL and 14C dating of moraines (from Yang et al., 2003, 2008; Rothlisberger and Geyh, 1985, Bräuning, 2006; Zhu et al., 2013; Xu et al., 2012; Hochreuther et al., 2015; Loibl et al., 2015). Magnetic susceptibility from fjord sediments, Golfo Elefantes, of as a proxy for Gualas glacier fluctuations, Northern Patagonia, Chile (Bertrand et al., 2012). Glacier fluctuations in New Zealand based on 14C and 10Be dates (Schaefer et al., 2009; Putnam et al., 2012, modified). The colors in the background highlight the well-dated advances (orange) and retreat (gray) during the MCA and early 1st millennium in the Alps to enable the interregional comparison. Dashed horizontal lines represent the modern ELA or front positions in the end of 20th-early 21 st centuries.

Figure 5. Stacked time series of .the number of advances for each region documented in this review. The summary is based on 275 time series (Table 1 SM), with age control based on of the $14 \mathrm{C}$, TCNs, tree rings, and historical dates for ages of moraines, and periods of glacial activity recorded in lakes and marine sediments settings, and multiproxy reconstructions. Considering the heterogeneity of evidence used to infer former 
glacier extent, and because what constitutes an "advance" differs among authors, the number of advances (y-axis) should be regarded as approximate only. Nonetheless, several clear trends emerge. The series are of different nature and their number cannot be considered as numerical records. They show the number of cases when the signal of certain glacial activity is preserved either as geomorphic features or as sediment layers. A small number of glacier advances recorded occurred in many regions between the 1st and 12th centuries $\mathrm{CE}$, indicates that there were a number of advances over this time in many regions that are close by magnitude to those occurring later in the second millennium $\mathrm{CE}$, however although most advances were probably of smaller extent than during the 2nd millennium and their traces are not preserved (see Section 4 "Regional description"). An abrupt increase of the number of recorded advances starting in the 13th century and lasting through to the 19th century indicates both widespread glacier growth and greater preservation because these moraines have not been obliterated by larger advances, i.e. the advances of this time were of larger magnitude. After these maxima glaciers started to recede with re-advances of smaller extent therefore the number of records after the maximum continue to increase (generally in the $19^{\text {th }}$ to early 20 th centuries).

Figure 6. Number of glacial advances, temperature reconstruction and climatic forcings. (A) Total solar irradiance anomalies (Steinhilber et al., 2009). (B) Reconstructed global volcanic aerosol forcing from bipolar sulfate composite records from tropical (bipolar) eruptions (Sigl et al., 2015). (C) Multi-proxy temperature reconstruction of the Northern Hemisphere (CE 1-1979 (red) with its 80-yr component (blue) and the instrumental record (green) (Moberg et al., 2005) (D) Number of glacial advances normalized and 
inverted (avereged for the high and mid latitudes of the Northern and Southern hemispheres and from the tropics). See also caption of Figure 5.

\section{Graphical Abstract}

Number of glacial advances, temperature reconstruction and climatic forcings. (A) Total solar irradiance anomalies (Steinhilber et al., 2009). (B) Reconstructed global volcanic aerosol forcing from bipolar sulfate composite records from tropical (bipolar) eruptions (Sigl et al., 2015). (C) Multi-proxy temperature reconstruction of the Northern Hemisphere (CE 1-1979 (red) with its 80-yr component (blue) and the instrumental record (green) (Moberg et al., 2005). (D) Number of glacial advances normalized and inverted (averaged for the high and mid latitudes of the Northern and Southern hemispheres and from the tropics, cumulative curves).

Table 1 right column

\begin{tabular}{l}
\hline References \\
\hline Barclay et al., 2009 a, b, \\
this paper \\
Wiles et al., 2008 \\
This paper \\
Mood and Smith, 2015 \\
Anderson et al., 2008; \\
Miller et al., 2012; 2013; \\
Margreth et al., 2014 \\
Winsor et al., 2014, Kelly, \\
Lowell, 2009 \\
Balascio et al., 2015 \\
This paper
\end{tabular}


Larsen et al., 2013

Guilizzoni et al., 2006

Reusche et al., 2014

Roethe et al., 2015

Nesje, compilation from

lake sediments

Matthews and Dresser

2008, Nesje et al., 2008

Forman et al., 1999; Polyak

et al., 2004

Lubinski et al., 1999

This paper

Nazarov et al., 2012

This paper

Le Roy et al., 2015

This paper

Röthlisberger and Geyh, 1985

Murari et al., 2014

Yang et al., 2008

Yang et al., 2008

Brauning, 2006

Stroup et al., 2014

Polissar et al., 2006

This paper

This paper

Karlen et al., 1999

Polissar et al., 2006 
Espizua and Pitte 2009

Villalba et al. 1990;

Masiokas et al. 2009a,

2010; Ruiz et al. 2012

Glasser et al., 2002;

Winchester et al. 2001

Harrison et al. 2008;

Masiokas et al. 2009a

Mercer 1965; Rothlisberger

1986; Aniya, 2011;

Masiokas et al. 2009a;

Strelin et al. 2014

Mercer 1965; Rothlisberger

1986; Masiokas et al.

2009ab; Strelin et al. 2014

Strelin et al. 2008;

Masiokas et al., 2009a

Schaefer et al., 2009,

recalculated from Putnam

et al., 2012

Putnam et al., 2012 
Table 1. Periods of glacier advances

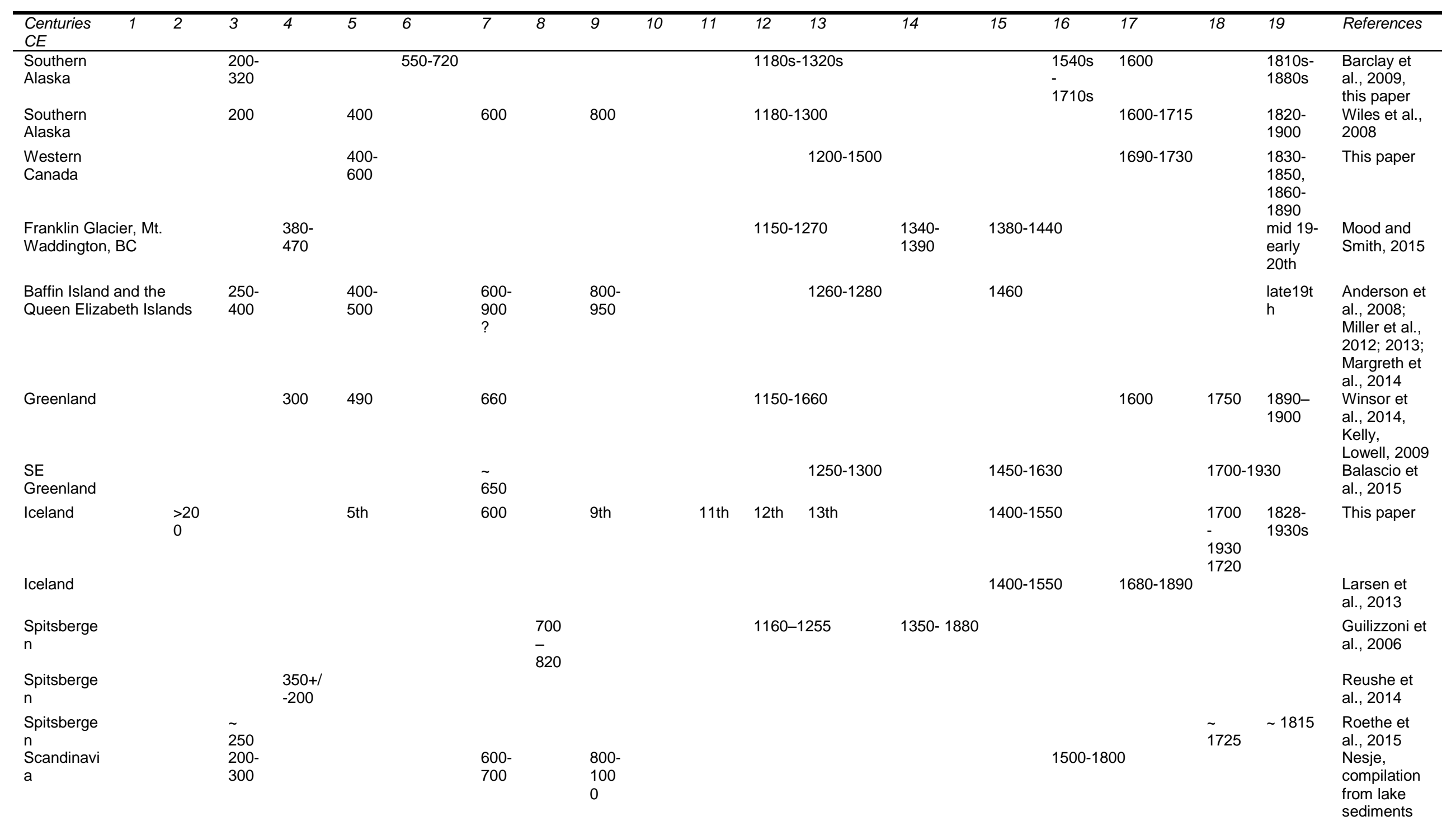




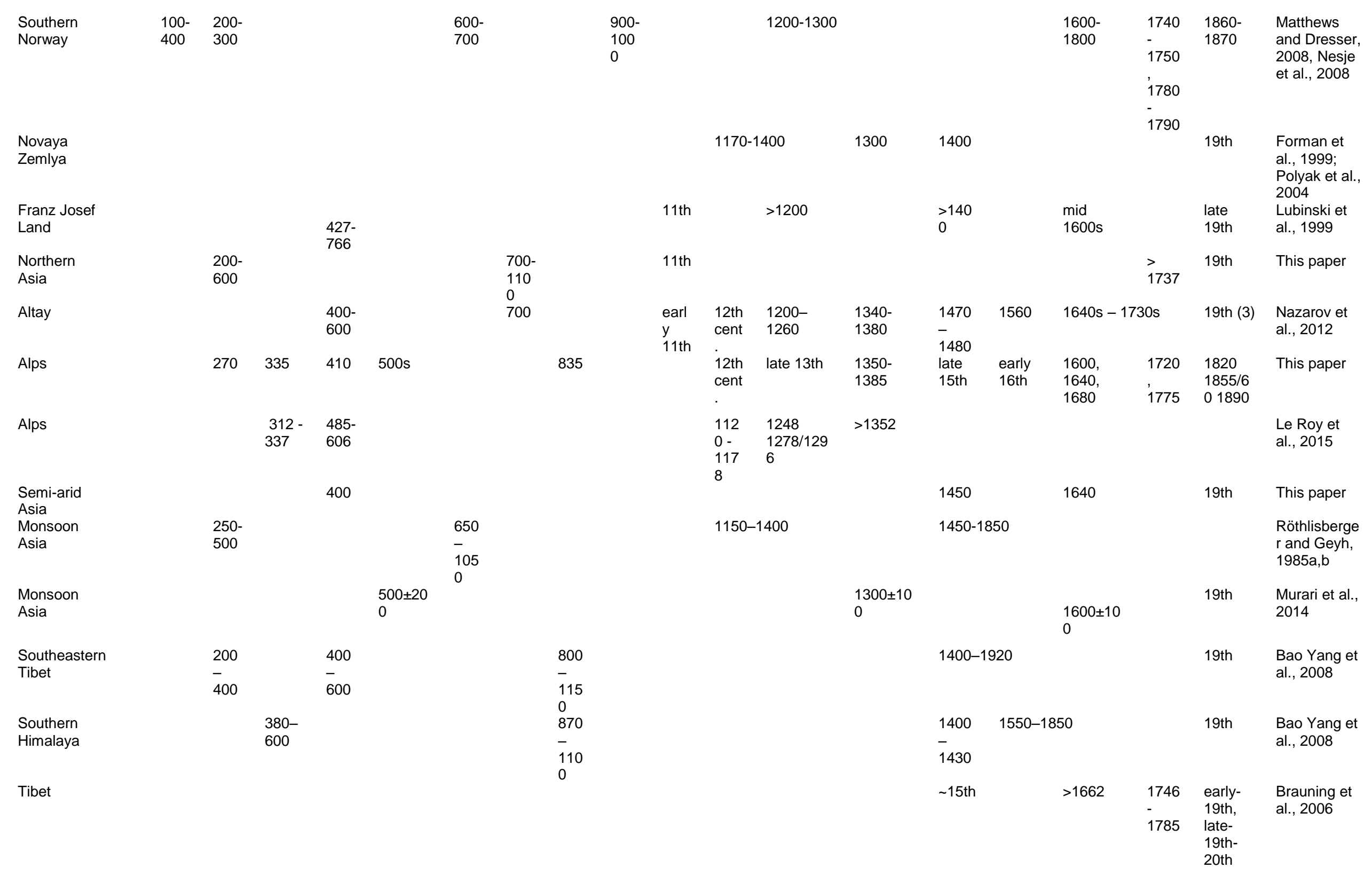


Qori Kalis outlet glacier

Quelccaya Ice

Venezuelian

Andes

Inner

tropics

Outer

tropics

Mt Kenia,

Africa

Andes,

Venezuela

Desert-Central Andes, Peñon, Azufre,

Damas glaciers

N.Patagonia, Tronador \&

Esperanza Glaciers

$1220-1350$

Northern

Patagonian

Icefield

Southern

Patagonian

$330-$

Icefield

$640-$

$1180-1350$

940

400-750

$1180-1350$ $\sim 1350$

1550

$1450-1590$

$1460-1660$

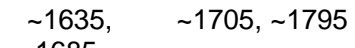

Stroup et al.,

Polissar et

al., 2006

This paper

1720-1780

This paper

$1610-\quad 1690-1800$

(1730)

Karlen et al.,

1999

Polissar et

al., 2006

Espizua and

1650s $\begin{array}{ll}1720 & 1850 s \\ & - \\ & 1790\end{array}$

Villalba et al.

1990;

Masiokas et

al. 2009a,

2010; Ruiz

et al. 2012

1850- Glasser et

1890 al., 2002;

Winchester

et al. 2001;

Harrison

al. 2008;

Masiokas et

al. 2009

Mercer

Rothlisberge

r 1986;

Aniya and

Sato 1995;

Masiokas et

al. 2009a;

Strelin et al.

2014

1500-1650

1740-1800

Mercer

Rothlisberge

Rothlis

r 1986;
Masiokas et 
al. 2009ab;

Strelin et al.

$$
2014
$$

Strelin et al

Masiokas et

al., 2009a

al., 2009a

Schaefer

al., 2009,

recalculated

rom Putnam

(3)

$\begin{array}{lll}100 & 115 & 1205\end{array}$

et al., 2012

New Zealand, Cameron

1350

1480

$1770 \quad 1864$

al., 2012 
Table 2. Periods of glacier retreats (glaciers as extensive as in the end of $20^{\text {th }}$-early $21^{\text {st }}$ centuries or smaller)

\begin{tabular}{|c|c|c|c|}
\hline Region, glacier & Dates, CE & Reference point & Reference \\
\hline Coastal and Southern Alaska & 950 & close to their modern margins & Wiles et al., 2008; Barclay et al., 2009a,b \\
\hline S. Alaska & 10th -13 th centuries & less extensive than at the late 20 th centuries & Wiles et al. 2008 \\
\hline Western Cordillera & before 500 & equal or smaller than in the late 20th century & $\begin{array}{l}\text { Allen and Smith, 2007; Clague et al., } \\
2010\end{array}$ \\
\hline British Columbia (Llewellyn Glacier) & before $300-500$ & no more extensive than today & Clague et al., 2010 \\
\hline SE Greenland (Kangerlussuaq) & until 200-250 & near the modern margins & Young and Briner, 2015 \\
\hline West Greenland (Jakobshavn İsbræ) & until 200-250 & near the modern margins & Lloyd, 2006 \\
\hline NW Greenland (Upernavik Isstrøm) & until 900-1200 & less extensive than now & Briner et al., 2013 \\
\hline SW Greenland (Kiagtut Sermia) & $660 \pm 150$ & within or near its present extent since & Winsor et al., 2014 \\
\hline Iceland & first millennium & $\begin{array}{l}\text { smaller than in the past millennium and on } \\
\text { some occasions smaller than those of today }\end{array}$ & Geirsdóttir et al., 2009 \\
\hline Spitsbergen (Kongressvatnet) & $\begin{array}{l}\text { before } 8 \text { th century, } \\
\text { probably up to before } \\
1370-1400\end{array}$ & $\begin{array}{l}\text { smaller than today (the presence of a glacier } \\
\text { signal is not detected in the sediments) }\end{array}$ & Guilizzoni et al., 2006 \\
\hline Spitsbergen (Longyearbreen) & $20-820$ & $2 \mathrm{~km}$ shorter than in early 20th century & Humlum et al., 2005 \\
\hline Spitsbergen & 2nd-6th centuries & smaller than during the past millennium & Reushe et al., 2015 \\
\hline Spitsbergen (Karlbreen) & $\begin{array}{l}\text { before } 50,550-750,800- \\
1100 \mathrm{CE}, \sim 1400 \text {, } \\
\text { between } 1720 \text { s and } \\
1810 \text { s }\end{array}$ & close to or beyond its present limit & Roethe et al., 2015 \\
\hline Norway (Juvfonne ice patch) & $250-530$ and $800-900$ & strong glacier retreat & Nesje et al., 2012 \\
\hline $\begin{array}{l}\text { Franz Josef Land (Cape Lagerny, } \\
\text { Northbrook Island) }\end{array}$ & $\begin{array}{l}\text { until at least CE 550- } \\
670\end{array}$ & beyond the present margin & Lubinski et al., 1999 \\
\hline Altay & 8th-12th centuries & retreat of unknown magnitude & Agatova et al., 2012 \\
\hline Alps & $\begin{array}{l}\text { before } 270 \text {, in the } 5 \text { th and } \\
\text { in the } 8 \text { th centuries }\end{array}$ & as small as in the late 20 th century & $\begin{array}{l}\text { Holzhauser et al., 2005; Hormes et al., } \\
\text { 2001; Joerin et al., } 2006\end{array}$ \\
\hline
\end{tabular}


Alps

Alps (Unteraar, Steinlimi and Lago di

Musella glaciers)

Swiss Alps (Glacier du Trient)

Tropical Andes (southern dome of the

Quelccaya ice cap)

Cordillera Real, Bolivia (Lago Taypi Chaka

Kkota) late 9 th to 11 th centuries

until 780

5th century

until CE 344-539

until CE 500-600 in retreated positions relative to the 17th-19th centuries

less extensive than present

as extensive as the late 20th century

smaller than it is today

smaller than today
Holzhauser et al., 2005; Simonneau et al., 2014

Hormes et al., 2006

Hormes et al., 2001

Mercer and Palacios, 1977

Abbot et al., 2000 

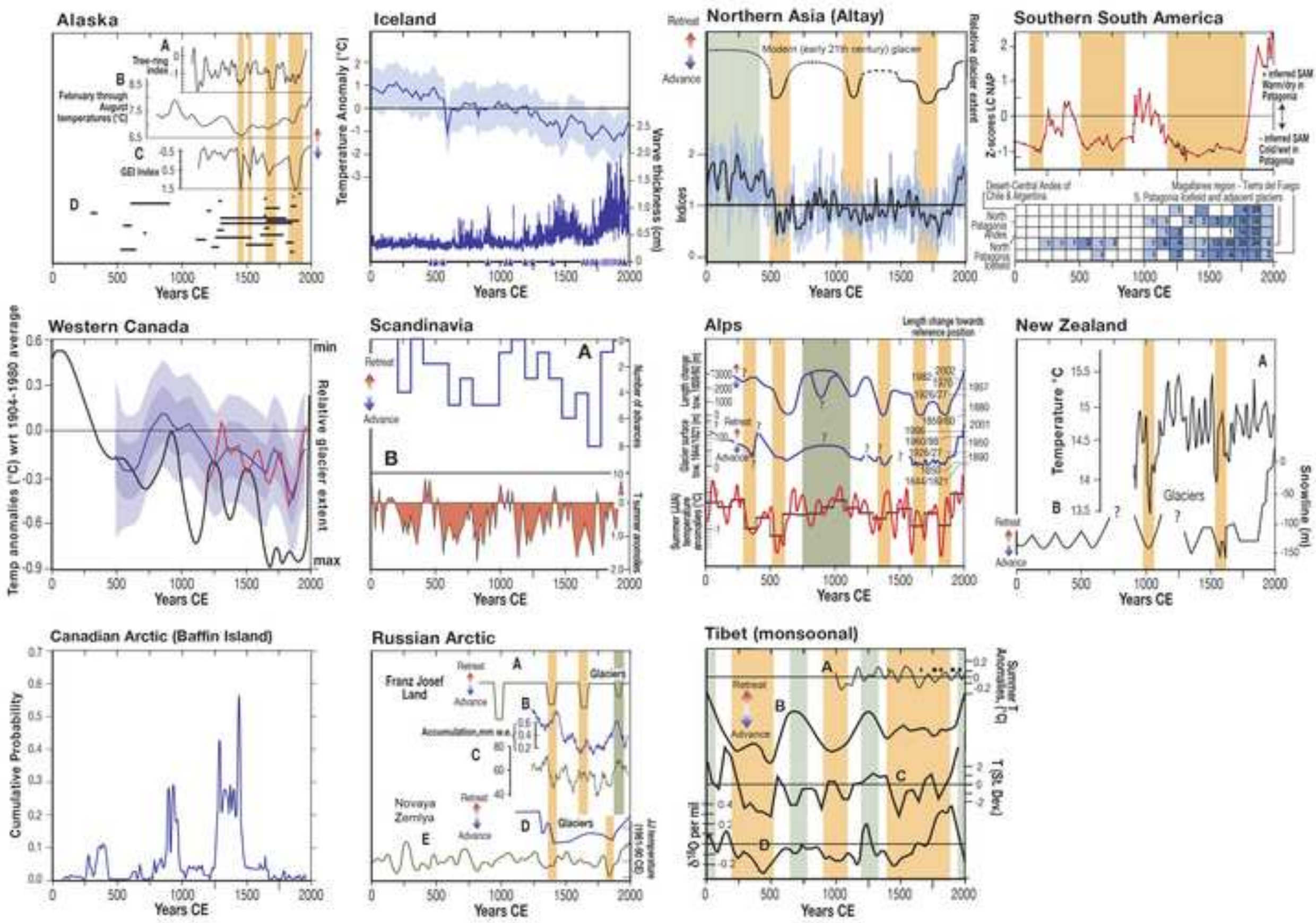


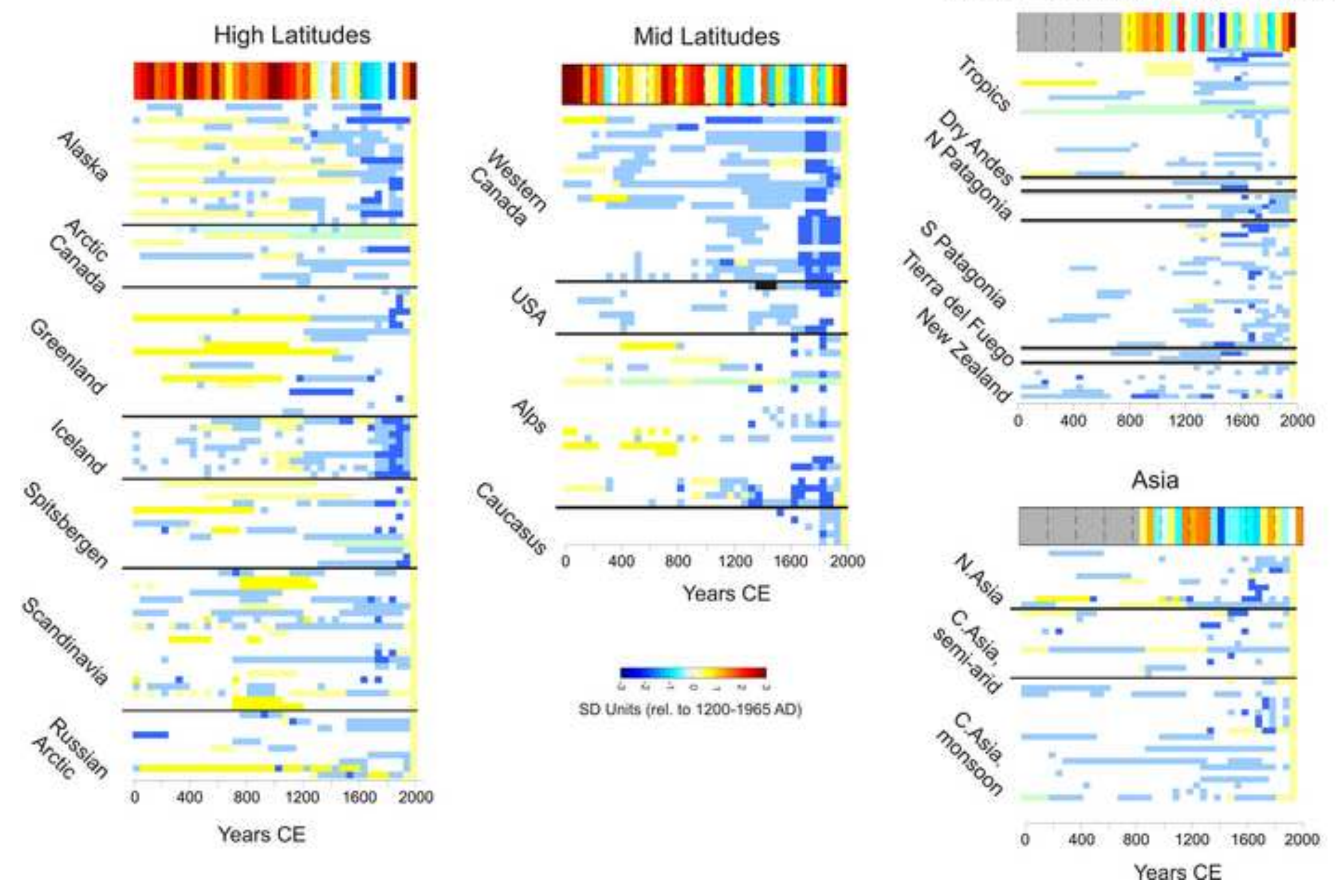




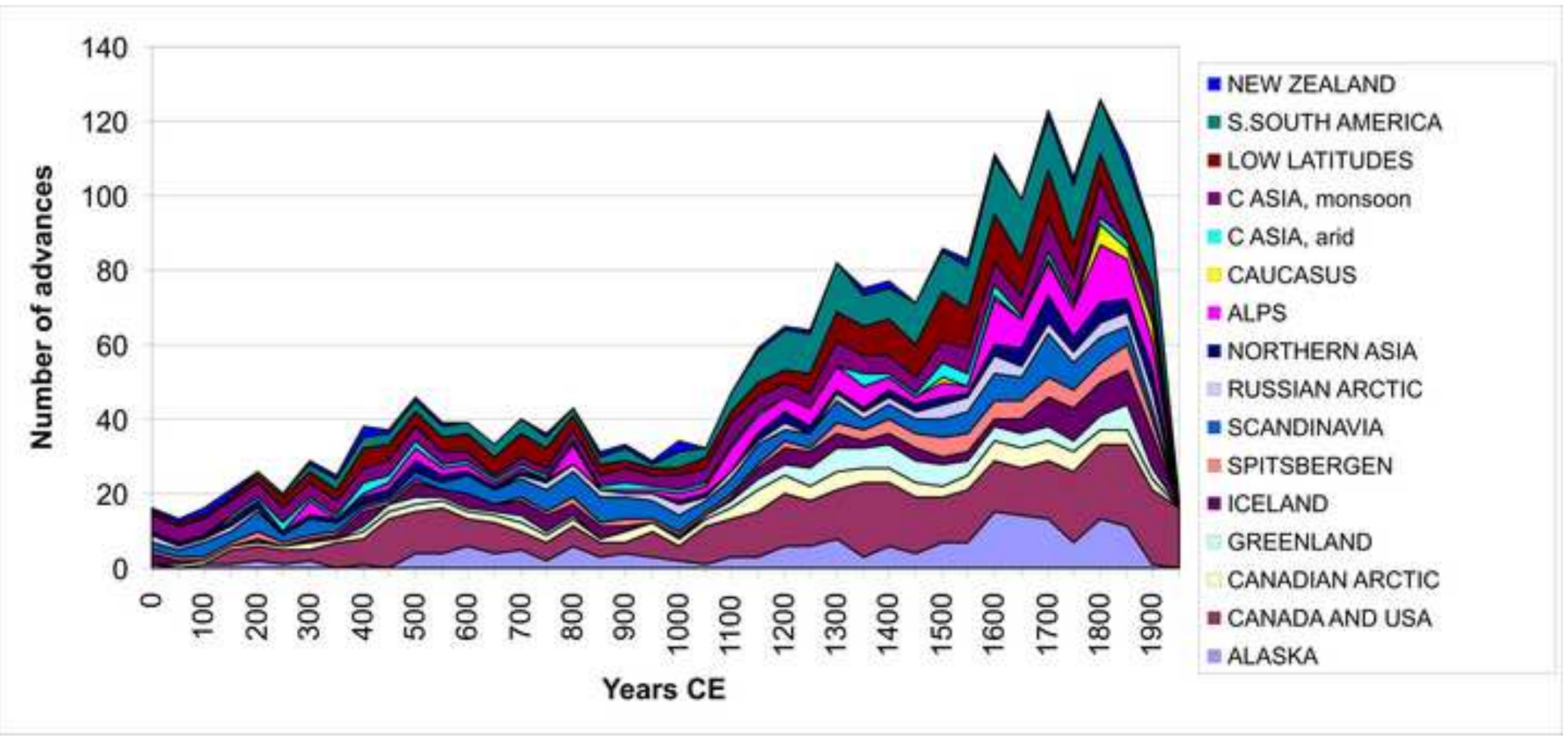



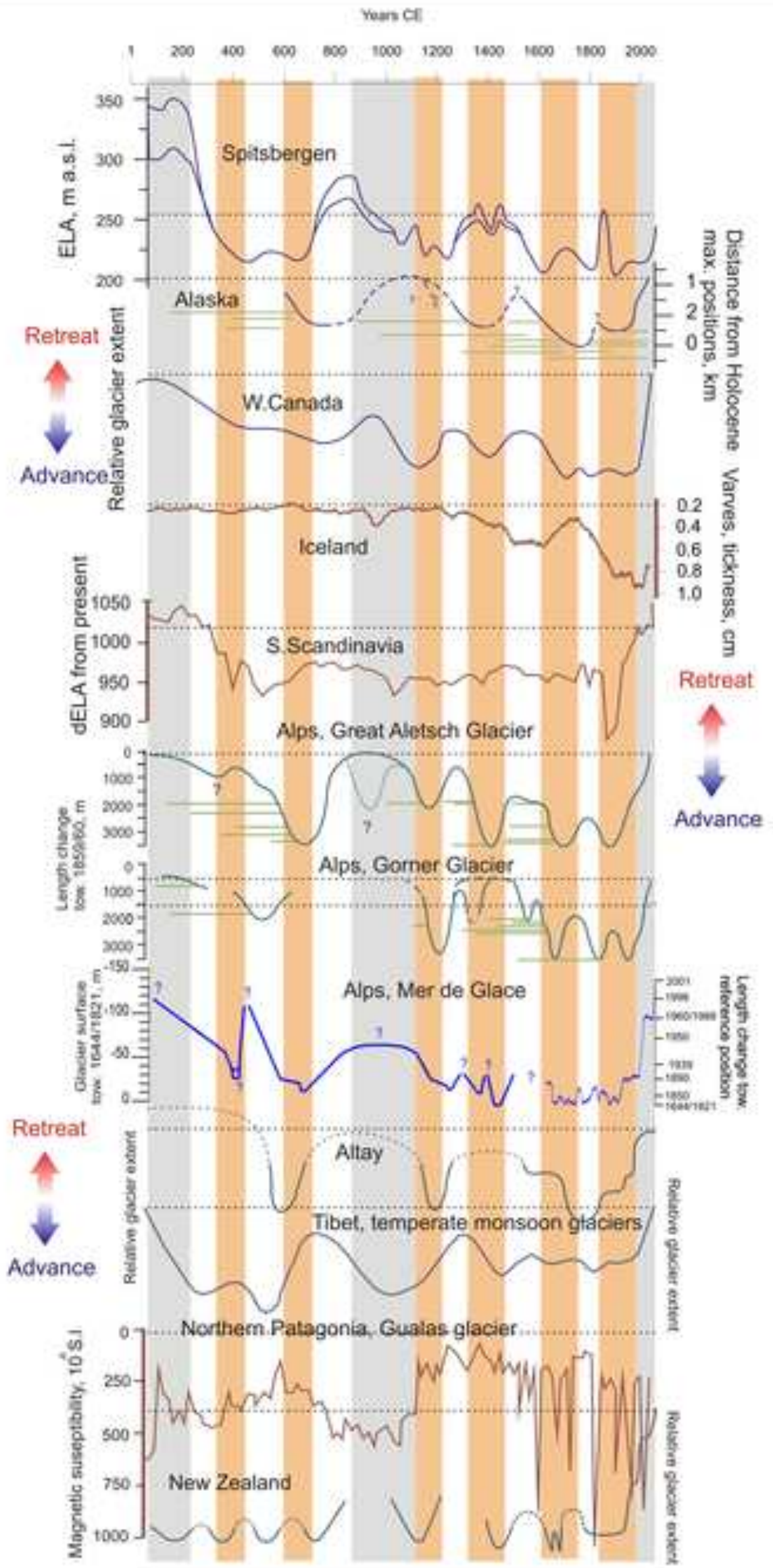

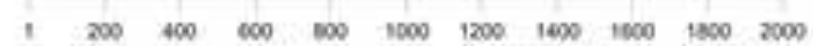

Vears CE 
Figure 5

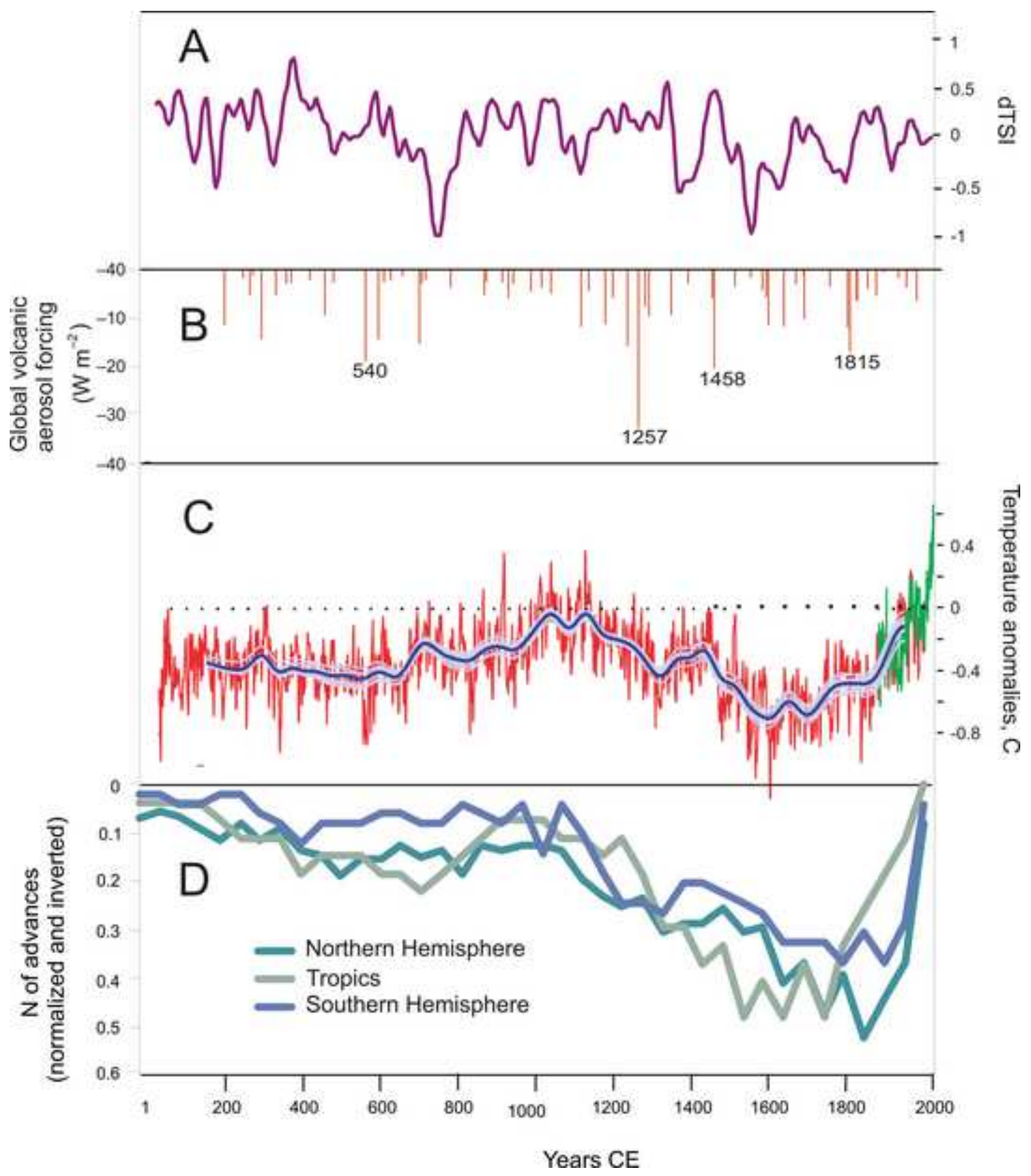




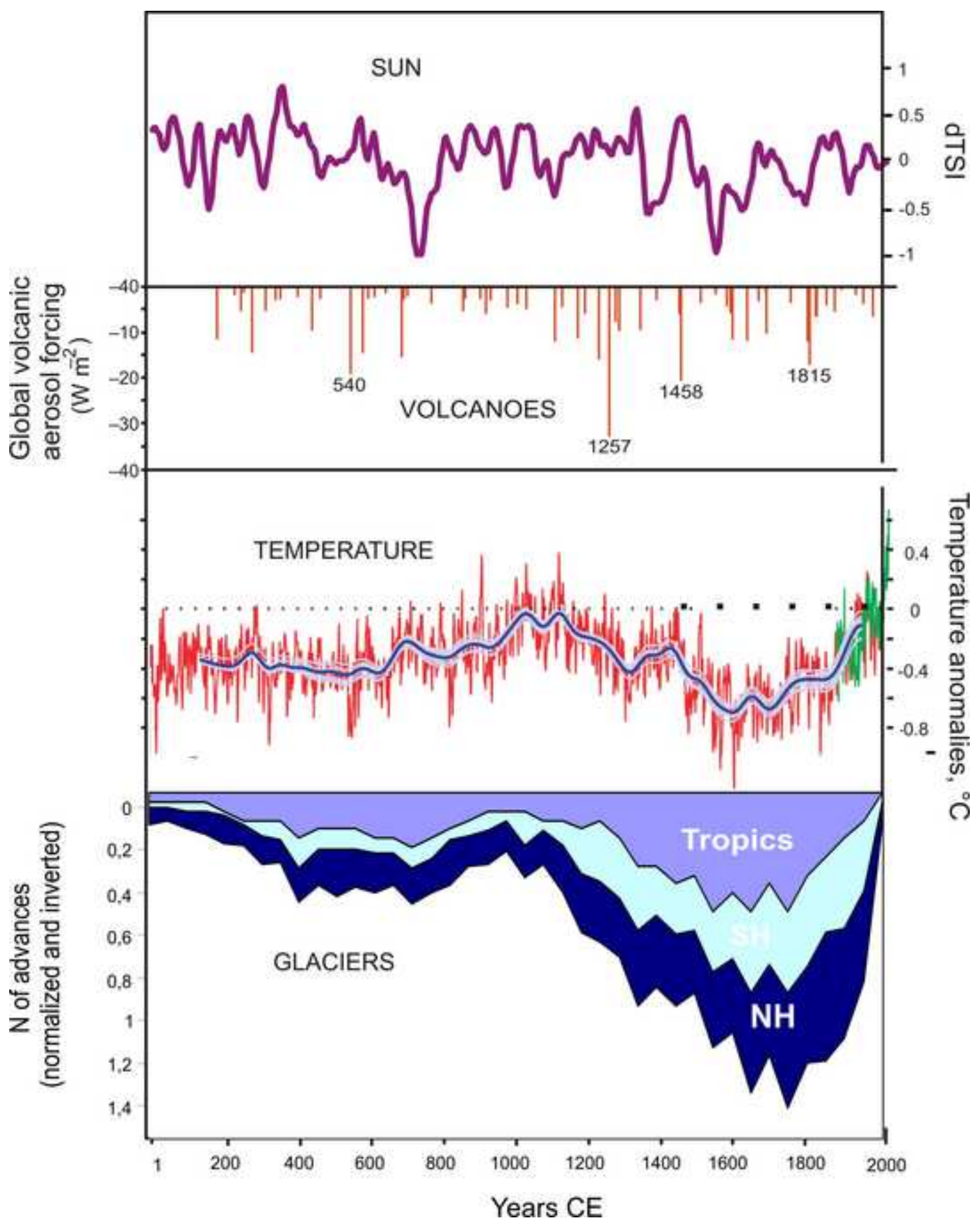

